\title{
AFRIKAANS: A LANGUAGE WHERE IDEOLOGY AND LINGUISTICS MEET ${ }^{1}$
}

\author{
CAMIEL HAMANS
}

To the memory of Hans den Besten

(1948-2010)

\begin{abstract}
This paper summarizes the discussion about the origin and the status of Afrikaans. Two schools appear to be opposed to each other: the philological school and a creolistic view. The philological school tried to demonstrate with meticulous research of sources that Afrikaans is a full daughter of $17^{\text {th }}$ century Dutch, which set foot ashore with van Riebeeck in 1652 at the Cape of Good Hope. Linguists who thought of a pattern of creolization in the formation of Afrikaans point to the influence of the languages of slaves brought to South Africa and to the influence of the original inhabitants, the Khoi and the San. This contribution mainly outlines the ideological background of these two schools of thought. For the philological school this is the system of Apartheid, while for the Creolist view the emphasis is more on decolonization.
\end{abstract}

Key words: Origin of Afrikaans, Apartheid, creolization, ideology

\section{Introduction ${ }^{2}$}

On 29 April 1882, Theophilus Hahn, librarian of the Grey Library in Cape Town and former student of August Pott, addressed the $53^{\text {rd }}$ Members Conference of the South African Public Library. In his days Hahn was considered to be a famous poly-

\footnotetext{
${ }^{1}$ Hans Henrich Hock was kind enough to read this paper carefully and to provide substantive and stylistic comments. The end product benefited greatly from this. Therefore, I am very grateful to him.

${ }^{2}$ This paper uses terminology that is common in the discussion about Afrikaans and its origins but may appear insulting to particular groups and in other circumstances. However, this terminology is retained here so as to accurately report the circumstances under which Afrikaans developed and continued.
} 
glot, fluent not only in the language of the Nama, the last survivors of the original inhabitants of the southern part of Africa, the Khoisan peoples, but also in the completely different tongue of the Herero, a Bantu ${ }^{3}$ ethnic group. In addition to these two exotic languages, he naturally also mastered Dutch and the modern foreign and classical languages. Moreover, he was one of Hugo Schuchardt's many correspondents whom he informed about the languages of the Namaquas and Griquas, formerly called Hottentots (Van der Wouden 2012: 110). The topic of Hahn's 1882 address was 'on the Science of Language and its Study, with special regard to South Africa'. In his speech he also mentioned 'Dutch' as it was spoken in South Africa.

One word about the Dutch patois of this Colony. It can be traced back to a fusion of the county dialects of the Netherlands and North-Western Germany, and although phonetically Teutonic, it is psychologically an essential Hottentot idiom. For we learn this patois first from our nurses and ayahs. The young Africander (sic!) on his solitary farm has no other playmates than the children of the Bastard Hottentot servants of his father, and even the grown-up farmer cannot easily escape the deteriorating effect of his servant's patois. It can hardly be expected that the descendants of Malayo-Polynesian slaves and Hottentot servants, who originally spoke an agglutinative language, will have any improving influence on an inflecting language.

Hanh's qualification of Afrikaans as essentially Hottentot and as an inferior, corrupted or deteriorated gibberish, albeit originally Dutch, set the tone for the discussion of the status and origin of Afrikaans for the next hundred years. In this contribution the discussion will be summarized and critiqued. Focus will be on the ideological backgrounds of the different positions.

In section 2 some important moments in the Afrikaner history are presented. Section 3 deals with the changing status and recognition of Afrikaans. Section 4 highlights the two most important opposing explanations regarding the origin of Afrikaans and their underlying ideological stances. Some widely discussed phenomena of Afrikaans, that are claimed to prove the correctness of one theory or the other, are presented in section 5. Section 6 is the conclusion.

\section{Some historical data $^{4}$}

\section{1. 'Refreshment station'}

It was Portuguese navigators and explorers who sailed around the southern tip of South Africa for the first time at the end of the $16^{\text {th }}$ century. Initially they called

\footnotetext{
${ }^{3}$ The term Bantu has been stigmatized politically in South Africa. Therefore, the term Sintu is now preferred in South Africa (Kotzé: 2018).

${ }^{4}$ For a full fledged history of Afrikaans South Africa, see Elphick and Giliomee (1989) and Giliomee (2009).
} 
this tip Storm Cape, Cabo Tormentoso, but later it was renamed Cape of Good Hope. Bartolomeu Dias, the first European to anchor at what is now called Mossel Bay in 1488, met small groups of indigenous people, Khoekhoen, formerly called Hottentots or Hotnots, who made a living as pastoralists. Dias and his successors tried to barter with the indigenous population to obtain fresh water and meat. From 1510, however, the Portuguese avoided the Cape after a skirmish in which Francisco d'Almeida, the first viceroy of the Portuguese State of India, was killed by a group of indigenous people. This unfortunate encounter did not mean the end of contact between European sailors and the Khoekhoen. Other nations such as the Danes, British, Dutch, and French still made stopovers at the Cape and exchanged tobacco, copper and iron objects, trinkets, and spirits for cattle and fresh water (De Villiers 2021: 39). Some of the Khoekhoen picked up enough of the language of the visitors to make themselves understood. Autshumao, or Herry/Harry de Strandloper 'sandpiper', chief of the Goringhaikonas, a tribe of fishermen, had even learned some English while on a voyage on an English ship (Ross 2017: 29; Gosselink 2017: 53).

In 1647 a Dutch Indiaman on its return voyage from Batavia, now Jakarta, to Amsterdam, ran aground near Bloubergstrand, part of Table Bay, 15 kilometer north of what later became Cape Town. Several members of the crew had to wait for more than a year before they could be transported home. The report of this group convinced the management of the Dutch East India Company, VOC, which was the only concession holder for trade with India and the East Indies, to establish a refreshment station at the shores of Table Bay. Therefore, they sent Jan van Riebeeck with three vessels to the Cape, where he landed 6 April 1652. The aim was not to start a colony but to only occupy a small stroke of land for the refreshment station (De Villiers 2012: 40-41, Carstens and Raidt 2019: 45). Unfortunately, this did not work well. The great number of sheep and cattle, 300 of each annually, which the Dutch needed for their sailors and refreshment station employees greatly exceeded the possibilities of the Khoekhoen. In addition, there was a need for vegetables. Hence some of the employees were granted land and a license to sell the proceeds from it. This can be considered the starting point of the Cape Colony (De Villiers 2012: 40-43).

\subsection{Early Cape Society}

The Dutch did not try to learn the language of the Khoekhoen; they considered that language with all its clicks too complicated. Despite this, they had to communicate with the Khoekhoen and thus had to make use of Khoekhoe interpreters. One of them was the aforementioned Autshumato who appeared unreliable, not as an interpreter but as chief of his tribe (Carstens and Raidt 2019: 48). His niece Krotoa, called Eva by the Dutch, became part of the household of Van Riebeeck and his wife 
from an early age. She spoke her mother tongue, Dutch, and Portuguese. ${ }^{5}$ In May 1662, a few days before Van Riebeeck left the Cape, she was Christianized. Krotoa, whose life ended tragically, regularly acted as an interpreter for Van Riebeeck and his staff, as the archives show, since she was the only person who not only mastered both languages but also possessed direct knowledge of both cultures. Krotoa married a white, Danish, employee of the VOC Pieter van Meerhoff. They had three children together (Jansen 2003a and b). ${ }^{6}$

Krotoa was not the only Khoekhoe woman who gave birth to children of Europeans. Since the VOC mainly sent male employees to the Cape, a shortage of white woman arose there. Consequently, there were quite some short-term or even longterm unofficial relationships with indigenous women, but marriages also occurred. Initially, this was not seen as a problem. For instance the mother of one of the $17^{\text {th }}$-century successors of Van Riebeeck, Simon van der $\mathrm{Stel}^{7}$ was mixed race (Nel 2016: 62). It was not until 1685 that a formal objection was made to mixed marriages. VOC commissioner Hendrik van Rheede who had been sent to the Cape as an inspector forbade 'full' mixed marriages, however he accepted marriages between Europeans and persons of mixed race. Of course this meant marriages between European men and mixed race women, half-slag slawe-vrouwe, in almost all cases. ${ }^{8} \mathrm{He}$ also ordered mixed race children to be taught to read and write so that they could be subsumed in European society (Shell 2012: 68-69). Both regulations were very partially implemented (Nel 2016: 62), ${ }^{9}$ although Van Rheede had the ordinance, a plaque against debauching, seducing, or taking slaves as concubines, publicly read and posted (Hulshof 1941: 213).

Van Riebeeck considered the Khoekhoen, being shepherds and live stock breeders, as unfit for agriculture and manual labor. He wanted visiting sailors to engage in

\footnotetext{
${ }^{5}$ Zimmer (1992: 349-350) noticed with admiration the great linguistic abilities of the Khoekhoen: 'They very soon spoke a fluent, but somewhat broken Dutch with the Europeans, and a form probably similarly affected of Malayo-Portuguese with the slaves.'

${ }^{6}$ During Apartheid Krotoa/Eva was hardly ever mentioned, and if so, only her tragic fate was taken as evidence that indigenous people cannot be successfully absorbed into Western culture and as a warning against miscegenation. Nowadays she is seen as a pivotal figure in the struggle of the indigenous people of South Africa for their recognition and their freedom. She is the protagonist of several recent books, stage works, and films, for instance the documentary novel by Trudie Bloem (1999) KrotoaEva.The Woman from Robben island. Cape Town: Kwela Books. The well-know Dutch-South African artist Marlene Dumas painted Krotoa's portrait (2016), which can be seen in Gosselink et al. (2017: 60).

${ }^{7}$ Simon van der Stel is indeed the founder of Stellenbosch.

${ }^{8}$ During the Dutch period, up to 1795 , more than one thousand female slaves and indigenous women married European men, whereas only two freed slaves married wives of European descent (Shell 2012: 69).

${ }^{9}$ Kriel (2018: 139-140) testifies that many of the halfsslag 'half caste' children were still absorbed by the white community during the first forty years after Van Rheede's ordinance. It was not until 1730 that the white community became strictly endogamous.
} 
this sort of work. The board of the VOC decided otherwise and gave Van Riebeeck permission to import slaves from 1658 on (De Villiers 2012: 45). Slavery persisted at the Cape till 1834. Most of the slaves were native from Mozambique, Madagascar, India, Sri Lanka, and the Indonesian archipelago and did not share a common language. Next to their native languages and Pidgin Dutch two lingua francas were used among them: Pasar Malay and Creole Portuguese (Van der Wouden 2012: 98).

\subsection{Migration at the Cape}

In 1685, the French king Louis XIV revoked the Edict of Nantes, by which his grandfather had granted freedom of religion to the French Protestants, the so called Huguenots. Many of them fled to the Netherlands of which several asked for permission to settle at the Cape, which was allowed. Between 1688 and 1692 a few groups of Huguenots arrived at the Cape, altogether 200 to 300 people. Most of them came with their families. In total they made up almost a quarter of the free civilian population at the time. (De Villiers 2012: 45). The then commander at the Cape Simon van der Stel was not very happy with the possible social and cultural dimension of this influx. He, being a veteran of the Dutch-French war of the 1670s, did not want to give up the Dutch identity of the colony. He was quite happy with the wine growing expertise of the Huguenots but ordered that they should be interspersed with the other burghers 'so that they could learn our language and morals, and be integrated with the Dutch nation' (Böeseken 1964, quoted from Giliomee 2009: 110). This worked quite well. Even though there are still many French family names in South Africa, the 'policy of forced cultural assimilation was largely successful; by 1750 no one under the age of forty could still speak French' (Giliomee 2009: 11).

The situation of the Khoekhoen at the Cape became increasingly dire at the Cape. Even though most of the Khoekhoe tribes were not very hostile to the Dutch occupiers, a few tribes continued to carry out attacks and commit cattle theft, which provoked violent reactions from the Dutch authorities. In addition, injudicious livestock trade and cattle diseases had impoverished the Khoekhoen, leading to many being employed as livestock guards by the free burghers. In 1713 a first smallpox epidemic spread, probably caused by contaminated linen from sailors on liberty, to be followed by a second and third outbreak in 1755 and 1767. The consequences for the Khoekhoen were disastrous. Some tribes were completely obliterated and others were decimated. Those who could save themselves fled and moved north. Consequently, there were no tribal Khoekhoen left at the Cape, only a very impoverished proletariat that no longer owned land and cattle and that had to give up its own language and way of life in order to survive. Their new language was a sort of Khoekhoe Dutch (De Villiers 2012: 47-48). 
The Dutch period, better the VOC government, lasted till 1795, when the British occupied the Cape Colony at the request of the Prince of Orange, the last stadholder of the Dutch Republic and in effect commander of the Dutch military, who had fled to England after French troops and Dutch revolutionaries had taken over the Netherlands. In 1806 British rule over the Cape became final. By 1820, some 4,000 British emigrants had already settled in the Cape Colony, making up a tenth of the European population (De Villiers 2012: 93). Lord Charles Somerset, British governor of the Cape Colony from 1814 to 1826 strove for rapid Anglicization of the newly acquired territory and therefore banned Dutch as the language of government and as language of instruction, which was met by much resistance. He even invited Scottish Presbyterian ministers to fill the vacancies of the Nederduitse Gereformeerde Kerk, the Dutch Reformed Church (De Villiers 2012: 95-96 and Giliomee 2012: 220-221).

This treatment by the British, who saw the Afrikaners as clearly inferior and second-class, has led to great bitterness among the original 'Dutch' population. This together with economic motives led to the Great Trek in 1835. The next two decades saw a mass migration of Dutch-speaking inhabitants, the Afrikaner Boers, from the Cape Colony north and eastwards in order to escape from the British colonial administration. The Great Trek ended up in regions populated by Bantu-speaking peoples. Obviously, the settlement by the Boers in the Bantu areas went not without struggle. Especially the Battle of Blood River, 16 December 1838, has grown to biblical proportion in Afrikaner mythology (Giliomee 2012: 222-223). In this battle, 500 Afrikaner Voortrekkers faced an army of more than 10,000 Zulu. "In a battle lasting two hours, three trekkers were slightly wounded and none killed, but three thousand Zulu lay dead" (Giliomee 20092: 165). The Boers were convinced that they owed their victory to a vow made to their Christian God before the battle: if victorious the day of the battle would be commemorated as a Sabbath. This victory over fearful odds seemed biblical and established the idea among the Afrikaners of being a people chosen by God (Giliomee 2012: 223), and it added to the conviction that the Boers could be put on par with Old Testament Israel, as the Afrikaner theologian and antiApartheid activist Theuns Eloff testified (De Vries 2012: 266). Jordaan (2004: 66) testifies how these kinds of stories that were told to her in her youth led to

the myth of the Afrikaner people as a special group of people, most of whom were actually heroes. ${ }^{10}$

This story of heroism, supported by the Christian God, that opened Africa to white civilization, became part of the Afrikaans narrative.

\footnotetext{
10 'die mite van die Afrikanervolk as ' $\mathrm{n}$ besondere groep mense, van wie die meeste eintlik helde was.'
} 


\subsection{Resistance against the British}

The Great Trek was successful and resulted in the establishment of the South African Republic, ZAR, informally known as Transvaal republic, capital Pretoria, in 1852, and the Orange Free Sate, OVS, with Bloemfontein as its capital, in 1854. In 1867, however, diamonds were discovered in an area, now Kimberley, but then on the border of the English and Afrikaner spheres of influence and therefore disputed. Some twenty years later, rich gold veins were found in Witwatersrand near Johannesburg. These discoveries and the economic potential thereof inevitably led to tensions, which started with the British annexation of the diamond fields in Basotholand (Free State) in 1871 and resulted in the Anglo Boer Wars. The first war, 1880-1881, ended in a Boer victory, the second, 1899-1902, however, led to the complete defeat of the Boers, among other things because the British imprisoned the Afrikaner civilian population in concentration camps with more than 25,000 civilian casualties, 4,177 women and 22,074 children, and because the British used a scorched earth tactic so that all farms and other possessions of the rebellious Boers were destroyed (Giliomee 2009²: 255-256).

Clearly, this policy did not improve the relationship between the Afrikaners and the English. In addition, the policy of the British governor of the then established British Transvaal and Orange River Colony, Lord Alfred Milner, who strived for complete Anglicisation of these hitherto formally Dutch-speaking areas ${ }^{11}$, strengthened the Afrikaner nationalism (Langner and du Plessis 2015: 9). With the help of Dutch funds, Afrikaner leaders started their own Dutch-speaking Christian schools, and in 1909 the Suid-Afrikaanse Akademie vir Wetenskap en Kuns 'South African Academy for Science and Arts' was founded. One of its priorities was the recognition, study, improvement, and quality control of Dutch and Afrikaans in South Africa. By 1908, the language war had caught fire. A young pastor of the Low German Reformed Church and also chairman of the Afrikaanse Taalvereniging 'Afrikaner Language Association', Daniël F. Malan, gave a flaming speech on 13 August of that year Dit is ons erns 'We are serious', in which he called for equal rights for Afrikaans and in which he warned the English-speaking minority that the language issue was a serious problem. The importance of the emancipatory speech is symbolized in the language monument at Paarl, where 'DIT IS ONS ERNS' is emblazoned in capitals in the pathway leading to the monument. In his speech Malan established a direct, natural relation between language and nation, which was, incidentally, an almost generally accepted position in the $19^{\text {th }}$ and early $20^{\text {th }}$ centuries.

Every living, powerful language is born at the bottom of the people's heart (...) No linguist can make a living language, nor can a chemist create life in his laboratory (Langner 2014: 64). ${ }^{12}$

\footnotetext{
${ }^{11}$ In fact, these areas were no longer standard Dutch speaking, but already Afrikaans, but Afrikaans was not yet a recognized language. The fiction was held that the language was Dutch.

12 'Iedre lewende, kragtige taal word gebore op die bodem van die volkshart (...) Geen taalgeleerde kan ' $\mathrm{n}$ lewende taal maak nie, ewemin as wat 'n skeikundige lewe in sy laboratorium kan skep'.
} 
Due to wise diplomatic maneuvers of the former Orange Free State President Marthinus T. Steyn and his ally James B.M. Herzog, the Closer Union Convention of 1909-1909 accepted to include two equivalent official languages in the South African constitution, English and Dutch (Giliomee 2012: 275-280). Apparently, the status of Afrikaans was not high enough and therefore preference was given to Dutch. Nevertheless, English remained the language of prestige and the animosity between the two white groups remained the main political issue. The position of blacks and coloured ${ }^{13}$ people did not play any role in the political debates of the then formed Union of South Africa, a self-governing dominion of the British Empire.

At the outbreak of World War I, Herzog, who opposed South-African participation in this peoples war at the side of the UK, founded an anti-British opposition party, Nasionale Party, 'National Party'. One of the highest priorities of this party was the language issue (Giliomee 2012: 282). When the National Party won the elections of 1924, Hertzog became prime minister of a coalition government, which was able to introduce Afrikaans as an official language next to English and Dutch in 1925. In effect, this meant that Afrikaans took the place of Dutch. Formally, however, Dutch still remained a national language. The minister for the Interior, Education and Public Health responsible for the law that recognized Afrikaans was Daniël F. Malan. He left, however, Nasionale Party in 1934 since he opposed a merger of this party with an English-friendly party. He then founded a radical nationalistic party, Gesuiwerde Nasionale Party ‘Purified National Party' (Giliomee 2012: 292-300).

\subsection{Rise and fall of Apartheid}

In 1948 Malan won the elections and was able to form a government consisting of his party only, now called the Nasionale Party again. Among Afrikaners, this election result was seen as the ultimate and justified victory over their English compatriots. Malan could now give room to Hendrik Verwoerd, the ideologue of Apartheid, to develop and to implement its policies (Giliomee 2012: 307-309). In the 1970s, the hubris of the Afrikaner Nasionale Party government went so far as to require the introduction of Afrikaans as the language of instruction for a number of subjects, including mathematics, for black high schools as well. This lead to the Soweto Uprising of 1976 in which fell about 600 fatalities. This became the turning point in the political situation in South Africa. The 1980s were characterized by riots, resistance, and violence (Grobler 2012: 383-388). The Apartheid government

\footnotetext{
${ }^{13}$ The name coloured people does not have the negative connotations in South Africa that it has elsewhere. The accepted Afrikaans term is bruinmense 'brown people'. The spelling coloured is the accepted spelling in South Africa instead of colored. Therefore the British/South African orthographic form is used in this paper.
} 
still tried to reach a compromise by proposing a three-chamber parliament, ${ }^{14}$ a white chamber, one coloured, ${ }^{15}$ and one for Asians, but since no place was given to the black population, who were supposed to be citizens of quasi-independent homelands, Bantustans, this was in vain (Giliomee 2012: 399-401). The end of Apartheid came on 1 February 1990, when then president De Klerk released opposition leader and later first black president of the Republic of South Africa, Nelson Mandela (Giliomee 2012: 415).

Under his government a new constitution was accepted in which eleven languages are recognized as national languages, Afrikaans being one of these eleven (Giliomee 2009²: 644). In the new constitution of 8 May 1996 no longer the two white languages, English and Afrikaans, were privileged but multilingualism became the basis for the South African language policy. Article 6.1 of the 1996 Constitution says: "The official languages of the Republic are Sepedi, Sesotho, Setswana, siSwati, Tshivenda, Xitsonga, Afrikaans, English, isiNdebele, isiXhosa and isiZulu." "16 Article 5.a.ii and iii requires special care for the Khoi, Nama, and San languages, which are the languages of the original inhabitants of South Africa, and of sign languages. Art. 5.b.i and ii require promotion and respect for "(i) all languages commonly used by communities in South Africa, including German, Greek, Gujarati, Hindi, Portuguese, Tamil, Telugu and Urdu; and (ii) Arabic, Hebrew, Sanskrit and other languages used for religious purposes in South Africa." In addition, art. 6.5.a instructs a newly established institution, the Pan South African Language Board, to develop a policy to promote sign language and the minority languages, including those of the Khoekhoe (see Carstens and Raidt 2019: 660-666). It is remarkable that Dutch is not mentioned anywhere in the constitution. This language completely disappeared at the Cape and its place has been taken over by Afrikaans.

\section{The status of Afrikaans}

\subsection{Language mixing}

The crew with which Van Riebeeck set foot on land in 1652 was not regionally homogeneous and therefore also not with regard to language. After all, there was not yet a Dutch standard language at that time. The Low Countries were a patchwork of dialects, some of which were quite far removed from the dialects of the leading cities of the regions of Brabant and Holland. Moreover, quite a few of the members of

\footnotetext{
${ }^{14}$ The revision of the constitution of 1983 stripped Dutch of its last formal rights in South Africa. Afrikaans had finally completely replaced Dutch; Webb (2002: 74-75).

${ }^{15}$ Till 1951, coloured people ('bruinmense') were on the same electoral roll as whites. New laws introduced in 1951 laws denied non-whites the right to vote and urged black residents of South Africa to seek their future in their homelands, outside the areas reserved for white people (Scher 2012: 330-333).

${ }^{16} \mathrm{https} / / /$ www.justice.gov.za/legislation/constitution/chp01.html (retrieved 24.11.202).
} 
Van Riebeeck's group were German; several of them spoke Low German, whereas the others High German. Holland and especially Amsterdam were prosperous and economically attractive for immigrants and therefore were popular places to settle and to look for work. The Dutch republic was a trading nation with a large fleet of ships that required many hands. A considerable number of the VOC ship's crews and of the colonial VOC employees thus came from outside the Low Countries, so from outside what is now the Netherlands, Belgium, and Northern France. This influx of speakers without a 'Dutch' background led to a certain koinè in the $17^{\text {th }}$ century (Boyce Hendriks 1998); a similar development must have occurred on board and in and around the Cape Fort.

Kloeke (1950: 229-264) analyzed in detail the origins and background of the first Europeans at the Cape. In 1664, there were 321 whites at the Cape, of which he could figure out the origin of 264 adults. Of these 264 a majority of 64 people came from a Low German speaking region, the two provinces of Holland were only the cradle for a total of 58 people, 55 people originated from the rest of the Netherlands, 24 people were Flemish, 14 had a High German dialect as their mother tongue, 25 people were of Scandinavian origin, and 7 came from French speaking areas in Belgium and the North of France. The conclusion can only be that the language of the first settlers was rather heterogeneous and certainly not a standardized Dutch; however, they must have had a common means of communication, most probably an adapted Dutch.

Even though Van Riebeeck planned to teach the Khoekhoen Dutch hoping to turn them into useful workers (Carstens and Raidt 2019: 45), nothing came of it. The Khoekhoen and the slaves who where imported from 1658, however, picked up enough Dutch to be able to understand Dutch and to make themselves understood. VOC commissioner Van Rheede who visited and inspected the Cape in 1685 noticed that the broken Dutch of the Hottentots became so popular that there even was a chance that Dutch children would take over this pidgin, since white adults also started to use this gobbledygook.

It is customary among our people - when they teach the natives Dutch, that these natives speak very crooked and almost unintelligible - to follow the example of the natives. This goes so far that our Dutch children, following this example, are taught a broken language that is impossible to unlearn afterwards. It would therefore be better to introduce Dutch among the Hottentots, all the more because they do not lack the ability to pronounce all words precisely, without any mistake, provided it is shown to them correctly, which deserves more attention (Hulshof 1941: 36). ${ }^{17}$

17 'Hier is een gewoonten onder al ons volck, dat lerende dese inlanders de Nededuijtdsche spraek, en dat deselve die op haer manieren seer krom en bijnae onverstanelijk spreken, soo volgende onse haer daerin nae, jae soodanigh, de kinderen van onse Nederlanders haer dat mede aenwennende een gebroken spraek gefondeert werd, die onmogeijck sal wesen naederhand te verwinnen, veel min onder de Hottentots de Duijdsche taele in te voeren, daer het deselve niet en gebreekt aen bequaemheijt, sprekende alle 
Franken, a South African linguist and historian with a great penchant for archival research and a great interest in information about the civil relations and the effect these had on the languages spoken at the Cape in the last decades of the $17^{\text {th }}$ century, ${ }^{18}$ came across a copy of Van Rheede;s diary in Cape Town. On the basis of Van Rheede's information, Franken (1927) stressed the importance of the 'fornication' between sailors, VOC-employees, and free whites on one side and Khoekhoe and slave women on the other side for the development of a new language at the Cape. ${ }^{19}$ He also commented on the emergence of a new form of Dutch, a 'broken language' as Van Rheede called it, due to the contact between the different groups:

The physical Baster 'bastard' [coloured people $\mathrm{CH}$ ] as intermediary between the European and the slave created together with the wider spiritual contact, whether this contact is emphasized as crooked-Portuguese or crooked-Dutch, a new Dutch, a 'broken language' (Franken 1927: 38). ${ }^{20}$

Van Rheede visited the slave shed and was shocked by what he saw there. Nevertheless he noticed that the small children, whether they were white or black, walked around wildly, while they all spoke Dutch indiscriminately (Hulshof 1941: 184). It is not clear whether Van Rheede, when referring to the language of the children, meant proper Dutch or broken Dutch. Anyhow, it is evident that already in 1685 there was a group of people of mixed race at the Cape, 'coloured people', and that they spoke a mixed language, most likely 'broken Dutch', which also functioned as a mother tongue for a next generation.

\subsection{Language varieties}

However, this broken Dutch was not the only language at the Cape. The official language of the VOC remained Dutch. Foreign VOC-employees also had their own

woorden promt uijt, sonder eenigh gebreck, indien men haer die maer wel voorsegt, waeromtrent wel nodigh was, wat meer agt geslaegen wiert.'

${ }^{18}$ See for more details about Franken's studies Valkhoff (1971: 461 and 470-471).

${ }^{19}$ The Dutch historian Colenbrander (1902: 119), who studied the genealogy of the Afrikaner Boers and claimed that the Afrikaner Boer 'race' is of almost pure 'white' blood, must admit that in the early days of the settlement toen de blanke vrouwen schaarsch waren (...) en de eigenaardige moreele eigenschappen van het Boerenras zich nog niet had kunnen ontwikkelen, [er] een levendig geslachtsverkeer met slavinnen plaats [had] 'when white women were scarce (...) and the peculiar moral qualities of the Boer race had not yet developed, [there] was a lively intercourse with slave women.' Note that Colenbrander speaks without irony about 'special moral high qualities' of the Boers. Probably he attributed these qualities to the Boers on the basis of their heroic behavior in the recently ended Anglo-Boer War. The unequal struggle against the British had generated great sympathy for the Boers in the Netherlands and created an image of them as if they were a people of heroes of an exceptional moral level.

20 'Tussen die Europeër en Slaaf het die fisieke die Baster en die ruimer geestelike kontak, of nou nadruk gelê word op Krom-Portugees of Krom-Hollands 'n nuwe Nederduits, 'n 'gebroke spraek geskep'.' 
mother tongues, just as the Khoekhoen still had their own language. Krotoa, the Khoekhoe interpreter also knew Portuguese, which must have been Portuguese Creole, the lingua franca of the African and Indian colonial posts. Slaves brought in from these areas used different varieties of Portuguese Creole as their lingua franca, next to their native languages. The lingua franca of the slaves from the Indonesian archipelago was a form of Pasar Malay, 'Bazaar Malay'. Bouman (1924: 123) describes how a maidservant invited the traveler C. Frikius to the castle of the Cape in 1685 or 1686 with the words mari disini Senior! 'come to me, Sir'. Senior is of course Portuguese senhor, the two other words are Malay. Bouman adds that the Afrikaner author and language activist Gideon R. von Wielligh (1859-1932) told him that his grandfather still could speak what he called Malay-Portuguese. Von Wielligh himself described 'the last sobs of Malay-Portuguese' in an Afrikaans journal in 1917 and testified there that according to his grandmother, the third wife of his grandfather, his Oupa 'grandpa' Nikolaas von Wielligh who was born in the last decades of the $18^{\text {th }}$ century had learned this language from the slaves on their family farm. Gideon still remembered how Oupa used this language when talking with an old freed slave around 1865 (Hesseling (1919: 96).

What all this data makes clear and confirms is that the Cape was on the one hand a mishmash of languages, but on the other hand that there was one official language, Dutch. For instance commander Simon van der Stel wanted the French Huguenots to give up their language as soon as possible in order to prevent an even more prestigious language from getting the upper hand. Dutch remained the official language of the VOC till the British took over the Cape and next to this administrative and 'Biblical' language there were at least two, maybe three languages spoken at large at the Cape: a 'broken Dutch', Malay Portuguese or Portuguese Creole, and Bazaar Malay.

The Khoekhoen and people of mixed race who left the Cape during the smallpox epidemics and migrated to the North-West had given up their original language and adopted the 'broken Dutch' as their mother tongue. Part of this group is called Basters 'bastards', another group calls themselves Griquas. Another group is called Oorlams. A form of 'broken Dutch' also became the first language of the Muslim Malay people of slave descent who stayed at the Cape (cf. Kotzé 1989 and Davids 2011), the so called Slameiers or Slamaaiers ${ }^{21}$ (Grebe 2009: 30 and Carstens and Raidt 2019: 210). Their vernacular was called a kombuis-Hollands 'kitchen Dutch', a derogatory term (Hinskens 2009: 14). Incidentally, this term is also used for all sub-standard varieties of Afrikaans.

The Afrikaner Boers, who moved further east and north during the Great Trek in the English era, had already pushed the boundaries in the 18th century because they were in need of land for their farms and livestock. They settled in remote areas many hours or even days away from Cape Town, and thus did not stay in contact with

\footnotetext{
${ }^{21}$ The name Slameijer is a blend of the words Islam and Maleier, the Dutch word for Malay.
} 
formal Dutch except in church. Due to the vast expanse of their lands, many of them did not live close to their neighbors, but isolated with their families and their slaves on their own huge farms, leaving their children with very little or even without any school education. Consequently, these Boers developed their own language variety just as the Basters, Oorlams, and Griquas who lived in the North-West and the people, including the large group of Muslims just mentioned, who remained at the Cape but did not master and speak formal Dutch. Roughly sketched, these developments led to three main varieties of Afrikaans: Oranjerivierafrikaans 'Orange River Afrikaans, ${ }^{22}$ to which Baster-, Oorlam-, and Griequa-Afrikaans belong, Kaapse Afrikaans 'Cape-Afrikaans', which also contains the Afrikaans of the Muslim Malays, and Oostgrensafrikaans 'Eastern Frontier-Afrikaans, also called Grensafrikaans 'Frontier-Afrikaans', the language of the Boers. These three varieties of 'broken Dutch' differ significantly from each other (Van Rensburg 1989, 1990, and 2012a and Van Rensburg et al. 1997).

\subsection{First Afrikaans Language Movement}

With the definitive English takeover of power at the Cape in 1806, Afrikaners and their official language, Dutch, lost status. Serious efforts were made to anglicize the Cape Colony. In 1822 Dutch was replaced as language of politics, administration, and court, and from 1853 it was not longer allowed to speak Dutch in the colonial parliament (Hinskens 2009: 13-14). As can be expected, these attempts were not received with enthusiasm by all Afrikaners. Yet it took a while before real resistance arose. British annexations of Afrikaans-speaking independent regions north of the colony and the war for independence in the Transvaal in 1880-1881 'aroused sympathy among white Dutch-speaking South Africans in the Cape for their brethren in the north. Awareness of a common language, homeland, history, and origin fostered not only group solidarity against British hegemony but an inchoate sense of ethnic identity, whereby the term Afrikaner [formerly also Afrikaander $\mathrm{CH}$ ] came to acquire a political meaning' (Roberge 2003: 24-25). After all, one of the few tangible features the Dutch-speaking South Africans and their Afrikaner cousins in Transvaal and the Free State had in common, next to their Calvinist religion, was the common language. And thus, the language became a political issue.

In August 1875 a group of eight young activists under the leadership of the Dutch Reformed minister Stephanus J. du Toit met in Paarl, a town 60 kilometer North-East of Cape Town, where they founded the Genootskap van Regte Afrikaners 'Society of True Afrikaners', GRA, which in the first place aimed at promoting the use of Afrikaans as a written language and the use of Afrikaans in public domains

\footnotetext{
${ }^{22}$ Nowadays the Orange River is called the Gariep.
} 
next to advancing Afrikaner political interests (Roberge 2003: 25-26). The founding of the GRA, which soon also started its own newspaper with the significant name Die Afrikaner Patriot 'The Afrikaans Patriot' marks the beginning of the Eerste Taal Beweging, the 'First (Afrikaner) Language Movement'. Within a year Du Toit published the first Afrikaans grammar book Eerste Beginsels van die Afrikaanse Taal (1876), 'First Principles of the Afrikaner Language', which was soon followed by an enlarged English edition Vergelykende Taalkunde van Afrikaans en Engels (1897) 'Comparative Linguistics of Afrikaans and English'. (Carstens and Raidt 2017: 328). The GRA also published a 'propagandistic Geskiedenis van ons land in die taal van ons volk (1877) 'History of our Country in the Language of our People' and Geskiedenis van die Afrikaanse taalbeweging vir vrind en vyand (1880) 'History of the Afrikaans Language Movement for Friend and Foe' (Roberge 2003: 26).

One of the instigators of the Language Movement, the Dutch classics teacher at the local gymnasium in Paarl and teacher of Du Toit, Arnoldus Pannevis was so unfortunate as to miss the founding meeting of the GRA but he publicly called for a Bible translation into Afrikaans for the benefit of the coloured people. The founders, however, ignored his appeal and overlooked the coloured speakers of Dutch in their manifestos and other publications. It did not mean that the GRA also gave up its religious pretensions. By no means, it 'marked Afrikaans as a God-given emblem of the Afrikaner people that could be stipulated a priori (as opposed to a segment along a continuum of lects)' (Roberge 2003: 26; italics PR). Pannevis also explicitly claimed Afrikaans to be a gift from God to the Afrikaner people. In November 1874 he anonymously published an open letter in which he answered the question Is die Afferkaans wesentlyk een taal? 'Is Afrikaans essentially a language'. No doubt, for good reason, he used a biblical metaphor to describe Afrikaans in this letter.

Some people have told me: In our colony we do not speak anything other than English for some years; you do not have to worry about the Afrikaans language. You know what I said then: We are not going to drown little Moses in the English waters. We are going to make one broom box for him, just as Ashram did, and then let him be put in the reed and let us put Miriam as a guard on it. Soon the King's daughter will come and will raise little Moses in the King's palace. And then Moses will become another great and mighty man. Burghers enough (Carsten and Raidt 2019: 323). ${ }^{23}$

A few years later, Pannevis no longer needed a metaphor to describe the divine character of Afrikaans.

\footnotetext{
23 'Sommige mensen het my geseg: In ons kolonie spreek ons o'er eenige jare niks as Engels; jy hoef niet moeite te doen nie foor die Afferkaanse taal. Weet julle wat ik toe geseg het: Ons gaat die kleine Moses nie in die Engelse waters ferdrink nie. Ons gaat een biesekisje for hem maak, net as Asram gedaan het, en laat hem dan maar in die riet geset word en Mirjam as een wach daarby. Strak kom nog die Koning zyn dochter en voed die kleine Mozes op in die Koning syn palys. En dan word Mozes nog een groot en magtig man. Poorters genoeg.'
} 
(...) This language has been prepared for us by Providence in the course of time, that it might be our means of receiving and communicating knowledge: we must use it, when we will once become all that we can be for our selves and the world (Pannevis 1882, quoted from Noordegraaf 2004: 181). ${ }^{24}$

Pannevis stresses that, even though it descends from Dutch, Afrikaans is a different language and not only because of its different linguistic history but since it represents a different folk character, a term which reminds of Herder's Volksgeist 'national spirit, national character'. He claims that the Afrikaner identity can only develop fully if the Afrikaner language will prevail and can be used everywhere. The echo of Herder and Fichte is unmistakable. ${ }^{25}$ The Afrikaner people should realize that their 'nationality', which is their national identity, is contained in the language, he stated emphatically. Language should be goal and instrument of the upcoming battle at the same time.

Language must be the main target and weapon in the forthcoming or already begun root struggle. (Pannevis 1882, quoted from Noordegraaf 2004: 181). ${ }^{26}$

\subsection{Second Afrikaans Language Movement}

Even though the First Language Movement was a clear wake-up call and despite the publication of their numerous publications, which enabled them to initiate the standardization of Afrikaans, Du Toit and his friends were politically not very successful. This changed after the Second Anglo Boer War of 1899-1902. English jingoism became so vehement that it asked for a response, which led to the Second Language Movement, and which could be described as a continuation of an average emancipation movement, ${ }^{27}$ if it had not been so full of nationalistic sentiments that

24 ' $(\ldots)$ deze taal is ons door de Voorzienigheid in de loop des tijds bereid, opdat zij ons het middel zou zijn om kennis te ontvangen en mee te delen: deze moeten wij gebruiken, zullen wij eenmaal voor ons zelven en de wereld al datgene worden wat wij kunnen zijn.'

${ }^{25}$ See for the influence of the 'German Romanticism' of philosophers such as Herder and Fichte on the Afrikaner Language Movement and subsequently on Apartheid also Kriel (2013: 77), Kriel (2018: 149) and Webb and Kriel (2000: 31-39). 'Herderian linguistic nationalism' was not only a $19^{\text {th }}$ century romantic feeling, it remained prevalent in Afrikaner circles for a long time. Webb and Kriel quote a textbook by Andries G.S. Meiring (1949: 10) who writes "Where no language lives, no nation lives" (Webb and Kriel 2000: 31). The Herderian equation of language and nation also formed the basis for the Apartheid Homeland policy, according to Webb and Kriel (2000: 39).

26 'De taal moet het hoofddoel en het wapen in de aanstaanden of reeds begonnen wortelstrijd wezen.'

${ }^{27}$ According to the famous Afrikaans literary historian John C. Kannemeyer, who published a history of the Afrikaans Language Movement (1974: 16), the aim of the Second Movement was 'to express the greatest needs and innermost being of the Afrikaner people', whereas the First Movement focused on the introduction and acceptance of Afrikaans as a written medium. 
were often combined with language. After all, the most important and perhaps only means of connection between the Afrikaner people, the only common feature of their identity, was still their language. The Afrikaner poet, language activist of the Second Movement, and politician Cornelis J. Langenhoven eloquently claimed such a coincidence of language and identity using words that positioned the Afrikaner Language Movement even more firmly in the romantic-nationalist tradition of Herder and especially Fichte.

A nation is not merely a collection of individuals, but an organic body with a national soul, and national speech is its expression (Langenhoven 1914, quoted from Kannemeyer $\left.1996^{2}: 326\right)^{28}$

Afrikaans is made in South Africa to suit our Afrikaans conditions and way of life; it has grown with our national character; it is the only bond that binds us together as a separate nation; our only national feature (Langenhoven 1938: 12, 371). ${ }^{29}$

As outlined in section 2, the Second Language Movement eventually led to the recognition of Afrikaans in addition to Dutch (and English) as the official language and finally to the formal replacement of Dutch by Afrikaans.

The special position the Afrikaans language had in the emancipatory struggle of the Afrikaners is symbolized in the striking Language Monument erected on the hills near Paarl. The first call for an Afrikaans language monument dates from 1942. In 1964, in the heydays of Apartheid, a competition was held and finally the monument was built between 1972 and 1974, followed by an official unveiling attended by 40,000 invitees in 1975, one hundred years after the founding of the GRA but a few months before the Soweto uprising. Two texts are placed on the monument, one by Langenhoven in which he predicts that the future of Afrikaans will be 'sky high' in die bloue lug, the other from an essay written in 1959 by the poet Nicolaas P. van Wyk Louw:

Afrikaans is the language that connects Western Europe and Africa; it draws its power from these two sources; it forms a bridge between the great bright West and the magical Africa - the sometimes still so obscure Africa; they are both great forces, what great can emerge from their union - that is perhaps what lies ahead for Afrikaans to discover. But what we should never forget, is that this change of country and landscape sharpened, kneaded and knitted this emerging language (...) And so Afrikaans became able to speak out from this new land (...) Our task lies in the use that we make and will make of this gleaming tool (ATM 2016). ${ }^{30}$

28 ' $n$ Nasie is nie bloot ' $n$ versameling van indiwidue nie, maar ' $n$ organiese liggaam met ' $n$ nasionale siel, en die nasionale spraak is die uitdrukking daarvan.'

29 'Afrikaans is in Suid-Afrika gemaak om te pas by ons Afrikaanse toestande en levenswys; hy het saamgegroei met ons volkskarakter; hy is die enigste band wat ons als ' $n$ aparte nasie aanmekaar bindt; ons enigste volkskenmerk.'

30 'Afrikaans is die taal wat vir Wes-Europa en Afrika verbind; dit suig sy krag uit dié twee bronne; dit vorm ' $n$ brug tussen die groot helder Weste en die magiese Afrika - die soms nog so ón-helder Afri- 
The monument, of which the main and biggest column, following Langenhoven's call, points to the sky represents Afrikaans, also leaves room for other languages that worked together to enable the emergence of Afrikaans: three small columns for Western European languages such as Dutch, Portuguese, German, and English, three round bulges symbolizing the languages of the Khoekhoen, of the other original inhabitants of the area, the San, formerly called Bushmen, and of Bantu languages, and a wall representing Malay. The threat of Soweto, however, already echoed in the words with which Prime Minister John Vorster added luster to the opening. He emphasized the right that Afrikaners had to be and to stay in South Africa, because Afrikaans had originated in Africa and thus is a product of Africa (Huigen 2008: 889).

It were not only Afrikaners who thought highly of their language. The wellknown German linguist and specialist on minority languages Heinz Kloss (1977: 10) praised Afrikaans as 'the only non-European and non-Asiatic language to have attained full university status and to be used in all branches of life and learning (...) All other university languages have their main basis in either Europe or Asia.' Kloss could not know that within 40 years Afrikaans would loose its full university status due to changes in the socio-political system. Kloss, who may be considered a friend of the then South African Apartheid regime, ${ }^{31}$ was joined in his eulogy by the American geographer, Africa specialist, and anti-Apartheid activist Edwin Munger (1974: 4) who called Afrikaans 'the newest of the world's well-developed languages'. Giliomee (2004: 1) quoted a personal communication by the Canadian political scientist Jean Laponce who supposed that besides Afrikaans only the major languages Hindi and Indonesian and the special case Hebrew were standardized and came to be used in all branches of life and learning in the $20^{\text {th }}$ century.

\subsection{The place of non-white Afrikaans}

The high opinion the African Language Movement had of their own language made them overlook two aspects that subsequently proved to be essential. This con-

\footnotetext{
$\mathrm{ka}$; hulle is albei groot magte, wat daar groots aan hulle vereniging kan ontspruit - dit is miskien wat vir Afrikaans voorlê om te ontdek. Maar wat ons nooit moet vergeet nie, is dat hierdie verandering van land en landskap as't ware aan die nuwe wordende taal geslyp, geknee, gebrei het (...) En so het Afrikaans in staat geword om hierdie nuwe land uit te sê (...) Ons taak lê in die gebruik wat ons maak en sal maak van hierdie glansende werktuig.'

${ }^{31}$ See Hutton (1999: 144-187) for Kloss' opportunistic and certainly not flawless behavior during the Third Reich. Later, Kloss (1978) reacted strongly against Creole theories of origin for Afrikaans. He expressed aloud the suspicion that these theories were merely posited mit dem Wunsch, die stolzen Buren zu verletzen durch den Nachweis, daß sie ihre Sprache eigentlich den Nichtweißen verdanken 'with the wish to hurt the proud Boers by proving that they actually owe their language to the nonwhites' (Roberge 1990: 147 fn. 4).
} 
cerns the fiction of Afrikaans as a language without variation and the denial to offer a place in the emancipation and standardization process to the coloured speakers of Afrikaans. This neglect was not only characteristic of the early years of the language movement, it has long left its mark on the pursuit of the elevation of Afrikaans. For instance, in the discussion about the symbolism embodied in the Language Monument a group under the leadership of the original chairman of the committee reverend P.J. Loots heavily protested against references to non-white contributions to Afrikaans. Not only were they unnecessary, but they were even based on a historical lie, according to him (Huigen 2008: 882 and Van Zyl and Rossouw 2016). In Loots' opinion and that of the media that reported about the unveiling of the monument, Afrikaans was mainly a witmanstaal 'white man's language' (Huigen 2008: 889).

The denial of the fact that not only white people spoke Afrikaans, but also many coloured people (Van Rensburg 1999: 81), including the descendants of the Khoekhoen, is a result of a mix of ideological views, some of which later also led to the Apartheid policy. Analysis of this Gordian knot of opinions and arguments in fact calls for a monograph. Due to limitations of space, only a few aspects of this complex problem can be highlighted here.

Even though all educated middle-class Afrikaners must have known that there existed other varieties of Afrikaans besides the one they spoke themselves, they did not accept these varieties as part of their civilized means of communication. In this respect, there is no essential difference between the attitudes of Afrikaans pastors, lawyers, schoolteachers, journalists, and other Afrikaans middle class people towards the 'uncivilized' language of lower social classes in the cities and in the country side on the one hand and the opinion of their counterparts in London or Paris towards the language of social lower classes on the other. The language varieties spoken by poor laborers, craftsmen, shopkeepers, and peasants were seen as uncivilized and therefore not apt for standardization. Afrikaans-speaking bourgeois circles did not differ from their European or American peers in this respect. As Stell (2010a: 110-11) puts is, it was a Cape-Dutch intelligentsia that started the First Language Movement and they choose the 'unspoiled' language of the proud and brave Voortrekker Boers, Frontier-Afrikaans, however combined with a few typical Cape-Afrikaans features to stress the distance with Dutch, as a binding symbol for the white Afrikaans speakers at the Cape. After all, they saw the language of the coloureds as ugly, corrupted, and bastardized. The author and language activist Von Wielligh (1925: 94), who was a link between the First and the Second Language Movement, described the Afrikaans of the coloured speakers as 'the lowest form ever achieved by Afrikaans' in his survey of regional varieties of Afrikaans. Rademeyer, who was the first to study the language of the Basters and the Griquas called their language 'deformed' and 'degenerated' compared to the 'generalcivilized language of South-Afrika'. The speakers of these varieties are an agterlik klompie wesens, a 'backward bunch of creatures', even tough most of them were not 
illiterate; their language has 'always served only one purpose: to amuse' (Rademeyer 1938: 5 and 11-12).

No wonder, that the GRA people believed that there was no variation in Afrikaans. Their leader Du Toit persisted that Van Tafelsberg tot Soutpansberg praast dir Afrikaner een taal 'From Table Mountain to Soutpansberg the Afrikaners speak one language (Du Toit 1891, quoted by Du Plessis (1987: 152-153). By neglecting the varieties of Afrikaans, the GRA simply disqualified the non-white varieties as possible part of their language. That their own language, however, was not as stable and homogeneous as they believed, will be discussed later.

\subsection{Nationhood}

Another argument for the denial of the role of coloured speakers of Afrikaans goes back to romantic-nationalistic ideas, usually attributed to the German philosophers Herder and Fichte but most common in the $19^{\text {th }}$ and early $20^{\text {th }}$ century. This tradition claims a direct and natural relation between Volk 'nation, people' and Sprache 'language'. The First and Second Language Movements were emancipation or self-affirmation movements by means of a language struggle, just as the Flemish language movement in Belgium. Taal, the Afrikaner word for language, has a much broader connotation than the Dutch word taal or the English language.

Taal gives the Afrikaners their identity. It is a product of historical struggle. It is its speakers' culture, their Kultuur (Kultuur refers less to the creative arts in Afrikaner usage than to the traditional forms of Afrikaner life - forms that have to preserved from outside interference and pollution.) Taal cannot in its implications be separated from its speakers' religion ... their community - their gemeenskap. It attests to their unity, which they call gemeenlikheidsgevoel (Crapanzano 1985: 30-31, quoted from Roberge 1992: 34).

The Dutch linguist Brill, who taught in Bloemfontein, claimed in a public lecture about the landstaal 'national language', presented in 1875 shortly before the founding meeting of the GRA, that 'the people are all the language,' which means, he explains, that 'when a people is a nationality, there will be one language'. This implies, he goes on, that a national identity should be fostered by promoting the national language, the study of this language, and the cultivation of a national literature (Noordegraaf 2004: 175). Looking back, the Afrikaans poet and literary scholar Vernon February notices how important the claim of being a unique Volk was to South African emancipators for more than one hundred years: 'Afrikaner scholars went out of their way to prove that they were unique as a Volk, while non-Afrikaners were fascinated by this species as a peculiar human type with a peculiar language and a peculiar culture' (February 2009²: 3).

Due to the loss of their independence, the Afrikaans-speakers at the Cape were not only second-class to the British who played the first fiddle, but more important- 
ly, they no longer formed a unity, no longer a Volk 'nation'. Their socio-political emancipation process therefore aimed at becoming, once again, a Volk through emancipation of their language. This nation which had to take its rightful place again consisted of the formerly ruling whites whose language was Afrikaans. Had the nonwhite African speakers also been included in this struggle, the so hoped-for emancipation would not have resulted in the return to power of the white Afrikaans people only, but the power should have had to be shared with the coloured Afrikaansspeaking people. Sharing of power, of course, was not the aim of the emancipation process. Dutch had been the language of white Dutch people. This Dutch had developed into Afrikaans, but remained seen as white and as a vehicle to reestablish the (white) Afrikaans nation.

The concept of nationhood and the belief that even though they basically shared a same language, coloured and whites did not belong to one and the same nation, to the same Volk, remained so common-place among whites Afrikaners that as recently as 1983 the wife of the then minister, later president, Frederik W. de Klerk could claim that coloured people are no nation and in fact are nothing.

But traditionally the Coloureds have no history of nationhood. They're a different group, i.e. all different types of people. Between us and [our] small group when the press aren't present. You know, they're a separate group. The definition of a Coloured in the population register is of someone who is not a Black, and not an Indian, in other words a nonperson. He is not...not...not. They're leftovers. They're people who were left over after the nations were sorted out. They're the rest. (...) Their binding power lies in the fact that they speak Afrikaans, that they're members of the [Dutch Reformed] Church. That is their binding power.

After a few remarks about the Indians, who live in South Africa, Mrs Marike de Klerk, continued:

They need a bit of supervision. And the supervision [and] our authority [baaskap] of the white [man] are built in the whole system. (Willemse 2011: 23; insertions HW)

An unidentified minister who took part in the discussion about Marike de Klerk's statement provided a striking conclusion to the exchange of ideas: 'Coloured people have no eie volksiel 'own nation soul' despite their Western cultural heritage, of which the language can be seen as a part' (Willemse 2011: 27).

As Willemse (2011: 25-27) shows, Marike de Klerk and the unidentified minister were not unique in their views. These ideas, which can be traced back to 'German Romanticism' of Herder and especially his followers and its focus on the Volksseele(Afrikaans Volksiel 'soul of the nation'), were shared by many Afrikaners of her time and before.

How important the idea of white nationhood was for the Afrikaner group, is shown by the statement of Henning Klopper, the organizer of the centennial of the 
Battle of Blood River in 1938. The white Afrikaans community celebrated this mythical event with a reconstruction of the Ossewa Trek 'Ox Cart Trek'. In the memorial book the leader of this event, which can best be described as an outburst of Afrikaner nationalism (Templin 1999), Henning Klopper wrote:

God Almighty, is the Creator of the universe. He created people and then called nations into his presence. He also called the Afrikaner people into his presence and gave South Africa to us as a home and a fatherland. The sense of freedom is a gift from God. No one was born to be someone's slave, personally, politically, economically, spiritually, or otherwise. The Afrikaner wants and will not be anyone's slave [here Klopper opposes British rule]. The rock from which we were hewn, the well from which we were dug, will never allow the ideal of a separate nationhood with all that it entails to be lost in every respect and in the fullest sense of the word for the Afrikaner.... Afrikanerdom, you have a wonderful future. Victory is yours. God has given South Africa to you. The Voortrekker ideals are still burning. The Woman of South Africa is alive. A light is burning on the horizon. The light of nationhood. Follow it, and you will live and celebrate (quoted from Jordaan 2004: 138; original italics). ${ }^{32}$

\subsection{Social Darwinism}

The second half of the $19^{\text {th }}$ century saw the emergence of quasi-scientific theories of racial difference and the dangers of racial mixing, called 'amalgamation' by the then popular 'American school of Ethnology', or, using another $19^{\text {th }}$ century American English pejorative term, 'miscegenation'. Most of these now scientifically rejected ideas go back to the French novelist and poet Arthur de Gobineau, who published his Essai sur l'Inégalité des races humaines 'An Essay on the Inequality of the Human Races' in two thick volumes in 1853. The starting point of Gobineau was that there is a hierarchy in races and their intelligence and thus in cultures and in languages. Therefore, mélange de sang 'mixing of blood' was dangerous and so it had to be warned about.

With the mixtures of blood come modifications in national ideas; with these modifications, a malaise that demands corresponding changes in the building (1853: I, 147). ${ }^{33}$

32 'God die Almagtige, is die Skepper van die heelal. Hy het mense geskape en daarna volke in syn aansyn geroep. Die Afrikanervolk het Hy ook in aansyn geroep en Suid-Afrika vir ons gegee as ' $n$ tuise en ' $n$ vaderland. Die vryheidsin is ' $n$ gawe Gods. Niemand is gebore om iemand se slaaf te wees nie, persoonlik, staatkundig, ekonomies, geestelik of andersins. Die Afrikaner wil en gaan niemand se slaaf wees nie [here Klopper opposes British rule]. Die rots waaruit ons gekap is, die put waaruit ons gegrawe is, sal nooit toelaat dat die ideaal van ' $n$ afsonderlike nasieskap met alles wat dit meebring in elke opsig en in die volste betekenis van die woord vir die Afrikaner verlore gaan nie... . Afrikanerdom, jy het ' $n$ heerlike toekoms. Oorwinning is joune. God het Suid-Afrika aan jou gegee. Die Voortrekkerideale leef nog steeds brandende voort. Die Vrou van Suid-Afrika leef. Voor in die wapad brand daar ' $n$ lig. Die lig van nasieskap. Volg dit, en jy sal leef en seëevier'.

33 'Avec les mélanges de sang, viennent les modifications dans les idées nationales; avec des modifications, un malaise qui exige des changements corrélatifs dans l'édifice.' 
Racial mixing usually has a negative effect, according to Gobineau. Only when two, strong races merge there is a change of reinforcement and improvement. In all other cases the effect will be negative.

Unfortunately, the great have been lowered by the same process [racial mixing $\mathrm{CH}$ ]; and this is an evil that nothing can balance and repair (Ifekwunigwe 2004: 39-40).

The same applies to cultures and languages.

Languages, inequal to each other, are in a perfect relationship with the relative merit of races. (Gobineau 1853: I, 307). ${ }^{34}$

Miscegenation between whites and blacks led to inferior people, coloureds, ${ }^{35}$ and also to an inferior, degenerate language. Rademeyer (1938: 10), who studied the language of the Basters and the Griquas, remarks that deficient coloured people have no choice but to speak a corrupted deviant language. The ideas of Gobineau were not exceptional in his days. The American School of Ethnology followed similar theories with names such as Joshua Nott, who published an article The Mulatto a Hybrid - Probable Extinction of the Two races if the Whites and Blacks are Allowed to Intermarry in 1843, Samuel Morton, a staunch craniologist, George Giddon, who together with Nott published a monumental work Types of Mankind (1854) which is now classified as a monument of racism, and the journalist Henry Hotze, who translated Gobineau's Essay in English (1856) and provided it with an introduction of more than one hundred pages of own invention. Racial mixing was a hot topic in the Unites Stated during the 1860s, since it was the time of the Civil War and the abolition of slavery. In this way the topic also became an issue elsewhere. In 1868, The New York Observer and Chronicle for instance published an article by a Swiss scientist Louis Agassiz about racial mixing in Brazil.

He stated that amalgamation was practiced more than anywhere else in the world, causing the deterioration of the country and produced a mongrel non-descript type, that was physically and mentally deficient (Brito 2016).

The discussion went world-wide. In London, Robert Knox, who criticized the Boer for being a cruel oppressor, claimed that 'nature produced no mules, no hybrids, neither in man nor animals'.

When they accidentally appear they soon cease to be, for they are either non-productive, or one of the other of the pure breeds speedily predominates, and the weaker disappears. This weakness may either be numerical or innate. That this law applies strictly to man himself, all history proves (...) (Ifekwunigwe 2004: 38).

\footnotetext{
${ }^{34}$ Les langues, inégales entre elles, sont dans un rapport parfait avec la mérite relatif des races.'

${ }^{35}$ Willemse (2011: 27) quotes the sociologist Geoffrey Cronjé (1945) who stated that "the "race quality of the Coloured was deficient."
} 
These ideas must also have reached Cape Town and together with the Herderian romantic-nationalistic theories they must have produced a poisonous ideological mixture that led to popular social Darwinism according to which people really believed that coloured people were a sort of bastardized race with inferior features and a deteriorate culture and language which was bound to disappear or to be put aside by stronger, superior races. The foreshadowing of The Third Reich and Apartheid is palpable.

Willemse (2011: 29) quotes a 1933 Stellenbosch M.A. thesis from 1933 by a certain McDonald in which the author bluntly states that the coloured 'was born in shame and in shame he continued his life and this to his own detriment and destruction'. A few years earlier Sarah Millin (1926) claimed that 'the coloured man is the fruit of the vice, of the folly, the thoughtlessness of the white man' (Willemse 2011: 31). Which emancipation movement wants to be associated with shame, vice, or thoughtlessness?

In the revised edition of his Groningen dissertation (1916) the linguist and later South-African ambassador to the Netherlands Daniel Bosman answered the remarks of his colleague Stephanus Boshoff, who criticized the way Bosman objected to the theory of the Leiden scholar Dirk Hesseling. Both Boshoff's and Bosman's comments undeniably demonstrate the influence of this racial thinking. Hesseling claimed that Afrikaner children at the remote farms who grew up together with the children of the slaves and of the Khoekhoe cattle drivers must have shared the 'broken Dutch' of these groups and in this way introduced the changes that caused Afrikaans to differ from Dutch. This is impossible, Boshoff said, since the young Afrikaners would give up the vernacular immediately, when they grew up and psychologically realized their racial superiority over the slaves. He wanted Bosman, who in fact agreed with him, to bring this argument to the front more emphatically. Bosman admitted that he should have stressed this argument more, citing a statement by yet another colleague that ruled out influences of indigenous languages on Afrikaans because of the white people's sense of superiority (Bosman 19282: 40-41).

The same Bosman, who later edited and published the diaries of Jan van Riebeeck, commented upon the tragic fate of Krotoa/Eva, the Khoekhoe interpreter of Van Riebeeck, who grew up in Van Riebeeck's family. After her European husband passed away, Krotoa was left without means of support with her young children. Probably because of this, she ended up in prostitution and got into drinking. Bosman then concludes:

Just as baptism is no guarantee of Christianity, so civilization is no guarantee of morality. With Eva [Krotoa], both chastity and morality were very superficial, just a layer of varnish. Each time she falls back into her original state of barbarism (Jansen 2003a: 74). ${ }^{36}$

In other words, you may take the human out of the animal, but not the animal out of the human.

36 'Soos die doop geen waarborg is van christelikheid nie, so is die beskawing geen waarborg van sedelikheid nie. By Eva was sowel chistelijkheid as sedelikheid baie oppervlakkig, bloot 'n laagje vernis. Telkens verval sy weer in haar oorspronklike staat van barbarism.' 


\subsection{Calvinist arguments}

The inferiority of non-whites, blacks, Indians, and coloured people, was also demonstrated by arguments derived from Christian faith. A classical and very popular argument for slavery in Christian exegesis was taken from Genesis, the Curse of Ham, actually placed upon his son Canaan (Gen. 9: 20-27). Ham, who was not ashamed to see his father Noah naked was therefore cursed by him: 'A servant of servants shall he be unto his brethren'. Ham would thus be the ancestor of all black peoples, as popular prejudice said. That is why they and their mixed offspring were condemned to slavery or subordination; being an underclass, they could not be or become part of the white Afrikaans nation (cf. Van Diemel 2016: 96-97).

In addition, the Afrikaners were convinced that a divine mission brought them to South Africa. Jan van Riebeeck was not only sent to establish a refreshment station and to make money for the VOC but also to bring the true belief and the light of God to Africa. Van Riebeeck thanked God in a prayer to be chosen to run business at the Cape

and to take such decisions where with all the greatest intent of the [East Indies] Company will be advanced and justice maintained. And it will be possible to implant and spread Thy Reformed Christian Teaching as time goes by, among those wild and savage people in praise and honour of Thy Holy Name (February 2009²: 7).

Of course, the missionary, the white man, is superior to the wild and savage, especially since it often appeared that the belief and the civilization of the converts was no more than a thin layer of varnish, as the fate of Krotoa/Eva showed. That could not be said of the Afrikaners; they were steadfast in their Calvinist faith. Therefore they were especially blessed by God. The Victory at the Blood River, 1838, had provided proof thereof.

Afrikaners themselves had no small hand in fostering this image of themselves - a 'chosen group' (...) with a continuing Western tradition and divine sanction (February 2009²: 3).

During Apartheid (1948-1994), Jan van Riebeeck was celebrated as a white saviour who had brought Christian civilization and thus light to dark Afrika (Posthumus 2020). But it was not only the white man and his white culture that were seen as couriers of Christianity, also the language of the white Afrikaners was sacred. To Paul Kruger, president of the independent Transvaal during the Second Anglo Boer War, is attributed the statement that he heard the voice of God in the voice of his people (February 2009²: 5).

Van Jaarsveld (1961: 11) points in this connection to the old opposition between Europeans and non-Europeans, as it was seen in the Calvinist tradition. Europeans are Christians, whereas non-Europeans were considered heathen, even though many 
coloured South Africans were Christianized. In the depths of their being, however, they were still pagans. Christianity was, of course, superior to paganism. It was via the Afrikaans language as bearer of the spiritual values of Afrikanerdom that Christianity and civilization had reached Africa (Jordaan 2004: 111). Roberge (1992: 38) points to the fact that the leader of the GRA. Du Toit, was a minister of the Dutch Reformed Church and that it was he who 'cultivated a mythology that fused Afrikaner history, the Cape Dutch Vernacular, and Calvinist theology'.

The central concept was that God Himself placed the Afrikaners in Africa and gave them the Afrikaans language. He entrusted them with a mission to spread Christian civilization to Africa.

In addition, the Afrikaner Dutch Reformed Church had good relations with the Reformed Churches in the Netherlands, an orthodox neo-Calvinist church movement that left the Dutch Reformed Church in 1886. Their leader, Abraham Kuyper, also established a political party, a newspaper, a university, the Free University in Amsterdam, and his own social pillar in the already highly pillarized Dutch society. Kuyper argued that Calvinism was more than a religion or theology. It was a worldview and should become a factor in society. Part of his worldview was the doctrine of sphere sovereignty, which says that each sphere of life has its own responsibility, competence, and authority.

Kuyper, who was also active as a politician, sided with the Boers during the Second Anglo Boer War. He was prime minister of the Netherlands during the last period of the war. As a member of parliament, he already campaigned against the "Perfidious Albion", as prime minister he did his utmost best to bring about peace in South Africa. When peace was reached, he published an article in which he sighed 'One thing has been preserved. Thank goodness, the language [Dutch]. And that is a lot. A lot for the future' (Crijnen 1999). No wonder that the Afrikaner Calvinists showed interest in Kuyper's political ideas. Kuyperianism became a major factor in the Afrikaner struggle for self-affirmation. The center became the Potchefstroom University in the north-western Transvaal (Kriel 2013: 76). One of the most outspoken representatives was the philosopher Herman G. Stoker, who became professor at this university in 1925. In his opinion, Divine Providence had a special purpose for the Afrikaner People, which should be seen as a 'divine ordinance' (Roberge 1990: 137).

God willed the diversity of Peoples. Thus far he has preserved the identity of our People. Such preservation was not for naught, for God allows nothing to happen for naught. He might have allowed our People to be bastardized with the native tribes as happened with other Europeans. He did not allow it. He might have allowed us to be anglicized, like for example, the Dutch in America. He did not allow that either. He maintained the identity of our People. He has a future task for us, a calling laid away. (Kriel 2013: 77). ${ }^{37}$

${ }^{37}$ Thisidea that the Christian God had a special plan for the Afrikaner people and Afrikaans held out for decades to come. Then President P.W. Botha thanked 'the Creator of all languages and nations 
The sphere sovereignty as defended by the Afrikaner Calvinists provided an extra argument to keep distance from the British oppressors but also to exclude nonwhites from their group (Willemse 2011: 26). In this way a mixture of Calvinist faith, $19^{\text {th }}$ century nationalism, quasi-scientific racism, and civil disregard of social lower classes led to the exclusion of non-white Afrikaans speakers from the language emancipation process and later to Apartheid in which all non-white people were socially segregated.

Carstens and Raidt (2019: 333), ${ }^{38}$ quote with approval the Afrikaans poet Daniel Hugo (2009) who concluded that the main fault of the GRA was that it never came to their mind to involve the coloured speakers of Afrikaans in the language struggle. ${ }^{39}$ Even worse, the Afrikaner Language Movement not only excluded non-whites from their ranks, in fact their striving can even be seen as a form of appropriation:

An ironic aspect of the Afrikaans language movement(s) was that the language was so totally appropriated by its white speakers: what was initially a language of the nonelite, the working class, black people, brown people, and uneducated white people, came to be regarded as the "exclusive" property of the white "elite" (despite, of course, the fact that more than half of its speakers were not white) (Webb and Kriel 2000: 22).

\subsection{Homogeneity}

So far a glimpse has been shown of the complex arguments regarding the refusal by the Afrikaners to allow their coloured fellow speakers of Afrikaans in the Language Movement. ${ }^{40}$ Therefore their language varieties were excluded to play a role in the process of standardization and this is also why the language activists could falsely suggest that Afrikaans was homogeneous, and thus originated from a homogeneous, Dutch, source. But even the white language which was to promote to the standard was not homogeneous, as Ana Deumert (2004) demonstrated.

[volkere]' for his 'miraculous gift to our soul' at the parliamentary celebration of the 60th anniversary of the recognition of Afrikaans in 1985. A few weeks later at a ceremony at the Language Monument in Paarl he claimed that 'the creation of another [Afrikaner] civilization, with a new language of Africa [Afrikaans],' was God's plan. 'Afrikaans is the God-given instrument used by millions of people in Africa when performing their daily task (...) when playing, but also when praying (...) when they serve their Creator' (Webb and Kriel 2000: 42).

${ }^{38}$ The second volume of this new handbook on the history of Afrikaans can be considered a continuous plea for an inclusive approach to Afrikaans, i.e. for a correction of the previously made mistakes of excluding non-white speakers of Afrikaans.

39 "Dat dit skynbaar nooit by hul opgekom het om die Afirkaanssprekende bruinman in die taalstryd te betrek." (Carstens and Raidt 2019: 333).

${ }^{40}$ In his Ghent dissertation (1905: 105), the Afrikaans linguist Pieter du Tout claimed that the language of the white Afrikaner speakers did not show any dialectal variation; the Afrikaans, however, of the coloured speakers showed enormous differences, he confirmed. 
The claim that Afrikaans was a homogeneous language without much variation, however, was not a product of the 'true Afrikaner' language activists of the GRA or of the Second Language Movement. Already the first grammarians who published about Afrikaans had and kept the delusion that Afrikaans is a language without variation.

It is still striking how the first linguists, in fact without exception, saw Afrikaans as a language without variation. Changuion (1844) himself, Mansvelt (1884), Viljoen (1896), and also S.J. du Toit [the founder of the GRA CH] are of the opinion that Afrikaans "from the Cape to the Limpopo" is one language, without significant variety. According to my opinion, the main reason for this lies in that by the end of the last century Afrikaans had begun to be a standard language, and for many of them it had centered on Afrikaans as a national language. It was important for them to free Afrikaans from its patois-label, because then dialect still meant more or less unacceptable deviation (Du Plessis (1995: 145). ${ }^{41}$

In 1882 Hugo Schuchardt, who was interested in Afrikaans since he expected to come across Creole phenomena in Afrikaans, wrote a letter to Johannes Brill in Bloemfontein in which he asked for information about Afrikaans and the possible influence of other languages on Afrikaans. Brill's answer did not differ from what he stated in his 1875 Bloemfontein lecture.

In the whole of South Africa - with the exception of the larger cities and the eastern part of the Cape Colony and Natal - only one language is spoken: the so-called Cape Dutch (Noordegraaf 2004: 173). ${ }^{42}$

Brill admits that there may be some kleine dialektische Eigenthümlichkeiten 'small dialect peculiarities'.

For example, Dutch as it is spoken in the vicinity of Cape Town may be different from the language of the Transvaal farmers in some respects (...) these differences are generally quite insignificant and where you come you will be able to understand others without any effort and even be understood by them (Noordegraaf 2004: 173). ${ }^{43}$

Even though Thomas le Roux in his phonetic description of Afrikaans (1910) pointed to differences and variation and although the language activist and author Gideon

41 'Dit is nog opvallend hoe die eerste taalkundiges Afrikaans feitliks sonder uitsondering as variasieloos sien. Changuion ${ }^{41}$ (1844) self, Mansvelt $(1884)^{41}$, Viljoen $(1896)^{41}$, en ook S.J. du Toit [the founder of the GRA CH] is gesteld daarop dat Afrikaans "van die Kaap tot by die Limpopo" een taal is, sonder noemenswaardige verskeidenheid. Die hoofrede hiervoor lê m.i. daarin dat teen die einde van die vorige eeu om Afrikaans as kultuurtaal begin gaan het, en dat dit vir baie van hulle om Afrikaans as nasionale taal gesentreer het. Dit was belangrik vir hulle om Afrikaans van sy patois-etiket te bevry, want toe het dialek nog min of meer onaanvaarbare afwyking beteken.'

42 'Im ganzen Süd-Afrika wird - mit Ausnahme der grösseren Städte und des östlichen Theils der Kapkolonie und Natal - nur eine Sprache gesprochen: das sogen. Kap-Holländisch.'

43 'z.B. das Holländische wie es in der Umgegend der Kapstad gesprochen wird, mag von der Sprache der Transvaalschen Bauern in einigen Hinsichten verschieden sein (...) diese Verschiedenheiten sind in allgemeinen genommen ganz unbedeutend und wohin man kommt wird man ohne Mühe andere verstehen können und selbst von ihnen verstanden werden.' 
von Wielligh published a first survey of regional varieties of Afrikaans in 1925, it took till the 1980s and the work of Christo van Rensburg before the obsession of Afrikaans as a homogeneous language was given up. ${ }^{44}$

The Standard Afrikaans that we know today developed roughly in the first quarter of the $20^{\text {th }}$ century (Roberge 2003: 31 ); the norm, however, was artificially set in the $19^{\text {th }}$ century.

[T] he standardization efforts of the first language society [GRA CH] drew on the wellknown imitations of Cape Dutch Vernacular speech which had been popularized in the Cape dialect literature from the 1830s. The Cape dialect writing tradition is best understood as a type of 'variety imitation' (...), that is out-group members (i.e. well-educated journalists and other middle class writers) imitate the marked linguistic behaviour of another social group (i.e. the language use of rural Cape farmers and artisans). Dialect imitations typically involve the overgeneralization of otherwise rare and variable linguistic features. (...) Gradually Cape Dutch writers created a relatively uniform representation of the 'vernacular' as an amalgamation of different non-standard features which did not necessarily coexist (...) in the speech of any individual, but which endowed the texts with the stereotypical characteristics of local speech and helped to establish a typological model of what constituted 'Afrikaans'. The process of creating a unified representation of the local vernacular was continued by the first language society when formulating the linguistic rules of the new standard - rules which defined Afrikaans as a uniform linguistic diasystem in its own right, independent of Dutch (Deumert 2002: 6).

A standard language originating from one dialectal source is highly exceptional; Afrikaans is not such an exception. Deumert (2004) shows that standard Afrikaans is composed by 'language engineers' (Grebe 2009: 21) on the basis of phenomena from different sources. ${ }^{45}$ In addition, Deumert concluded through an accurate analysis of private Cape Dutch documents from the last decades of the $19^{\text {th }}$ and the first of the $20^{\text {th }}$ century that the upcoming 'standard' language used at the turn of the $19^{\text {th }}$ and $20^{\text {th }}$ century varied widely. There existed a dynamic continuum of sociolects till at least 1900 , her sources demonstrate. The idea that there was one Afrikaans variety which could be traced back straight to Dutch varieties of the past thus becomes very implausible. Yet this is a thought that has been defended with fire for nearly a hundred years.

\section{Theories about the origin of Afrikaans}

\subsection{Earliest views}

Even though the first linguist who described the nature of Afrikaans, Theophilus Hahn (see section 1), described the language as a mixed language, as a product of

\footnotetext{
${ }^{44}$ The work of the pioneer dialect geographer Stephanus A. Louw, who published an atlas of Afrikaans, Afrikaanse Taalatlas, in 1959 focuses on the dialectal differences between Dutch and Afrikaans.

${ }^{45}$ The way Afrikaans is constructed reminds of the the way Ivar Aason designed Ny Norsk.
} 
Teutonic phonetics and Hottentot idiom, and as 'psychologically' Hottentot, his classification was not widely shared. Since he only (dis)qualified the language and did not give any arguments in his 1882 address, it was clear that one had to look for data and arguments. That is what Hugo Schuchardt, the father of Creole studies, did. He wrote a letter to Matthias de Vries, professor of linguistics at Leiden University and, as founder of the Woordenboek der Nederlandsche Taal 'Dictionary of the Dutch Language' (1864-2001, 43 vols), a central figure in the study of Dutch. Schuchardt asked for information about Afrikaans. De Vries advised him to contact Johannes Brill (see sections 3.6 and 3.9). Brill answered him that the language is pure Dutch

(...) only in a degenerate grammatical form. (...) Neither the Hottentot [Khoekhoe $\mathrm{CH}$ ] nor the Kaffir language [Bantu language] had the slightest direct influence on them, and this is as true of the inner parts of the country as it is of the immediate vicinity of Cape Town. There could be an indirect influence of the Malay and the African coloured people, insofar as they may have contributed more or less to the grammatical degeneration of the Dutch language, but such influence, although it has to be generally recognized, is difficult to demonstrate in detail (Noordegraaf 2004: 172-173). ${ }^{46}$

In fact, Brill claimed that the differences between Afrikaans and Dutch were the result of a spontaneous development, albeit that there may have been some influence from Malay speaking slaves and of the language(s) of the coloured people. It is not surprising that Brill did not agree with Schuchardt's Creole assumptions. After all, in his 1875 speech he had already explained that the wearing down of the Afrikaans word endings and the simplification of the forms in Afrikaans are a consequence of normal language changes based on the sound laws, as they also apply to the other Germanic languages (Van Niekerk 1916: 32).

Brill's answer did not convince Schuchardt, as his review of the first Afrikaans dictionary (1884) by Mansvelt (see fn. 41) shows. Schuchardt, who turned out to be very well acquainted with all the research into Afrikaans, partly due to references received from Matthias de Vries, as he indicated, concluded that

Cape Dutch [Afrikaans] is the result of a very strong and strange mixture of languages. (Schuchardt 1885: 466). ${ }^{47}$

46 ' (...) nur in entarteter grammatischen Form. (...) Weder die Hottentottische [Khoekhoe CH] noch die Kaffersprache [Bantu language] hat den geringsten directen Einfluss auf sie gehabt, und dies gilt eben so sehr von den innern Theilen des Landes wie von der unmittelbaren Umgegend der Kapstadt. Von einem indirecten Einflusse der Malaier und der Afrikanischen Naturellen könnte allerdings die Rede sein, in so weit als sie mehr oder weniger zur grammatischen Entartung der Holländischen Sprache mögen mitgewirkt haben, aber solcher Einfluss, obgleich er im allgemeinen anerkannt werden musz, liesze sich schwierig in Besonderheiten nachweisen.'

47 'Das Kapholländische ist das Resultat einer sehr starken und merkwürdigen Sprachmischung'. 
Schuchardt appreciated Mansvelts approach, especially since Mansvelt appeared to be able to find sources and roots for Afrikaans lexemes in older Dutch texts and Dutch dialects.

The Dutch foundation already shows, quite apart from the preservation of many old forms [and] very different dialect elements, in the determination of which the author has made an honest effort. (Schuchardt 1885: 466; spacing orginal). ${ }^{48}$

He criticised, however, the fact that Mansvelt underestimated the possible German influence on Afrikaans. Quite a number of the VOC employees, soldiers, and early colonists were German and that is why Schuchardt pointed to German roots.

And in this way, a lot of German came into Cape Dutch [U]nd so ist denn viel D e u t s c h e s ins Kapholländische gekommen (Schuchardt 1885: 467; spacing orginal). ${ }^{49}$

Later research, however, showed that Schuchard is mistaken in this respect.

Following Matthias de Vries, who described Afrikaans as Dutch in French, Huguenots' mouth, Schuchardt (1885: 468) also considered a possible French influence, which he rightly did not want to overestimate, even though he noticed a possible parallel between the brace negation ne ...pas in French and nie...nie in Afrikaans, which does not exist in Dutch, and and the coincidence of the subject and object forms of the personal pronoun 1st person plural, ons in Afrikaans and nous in French, whereas Dutch has two different forms e.g. wij (subject) and ons (object). The total number, however, of French words in Afrikaans appeared to be rather small. More interesting, he thought, are the Malay words in Afrikaans, just as the Portuguese, which show that there must have been a certain influence. The role of the indigenous languages, however, is much more intriguing.

The most important point of contention finally remains the question of the influence of the Hottentot language (the Bantu languages can be put aside) on the formation of Cape Dutch. (...) The question arises whether the Creole coloring, which the Cape Dutch wears, is to be put on account of the Hottentot language (Schuchardt 1885: 469). ${ }^{50}$

The idea of creole influences on the language of the white Afrikaner was not appreciated in South Africa. Johannes Brill (1910, quoted by Noordegraaf 2014: 527) attributed the rejection of Creole influence primarily on sentiment. For the white

\footnotetext{
48 'Schon der h o 11 ä n di s c he Grundstock zeigt, ganz abgesehen von der Erhaltung vieler Alterthümlichkeiten, sehr verschiedenartige dialektische Elemente, im deren Feststellung sich der Verf[asser] redlich bemüht hat.'

49 '[U]nd so ist denn viel D e u t s c h e s ins Kapholländische gekommen.'

50 'Als allerwichtigster Streitpunkt bleibt endlich die Frage nach der Einwirkung des Hottentottischen (von den Bantusprachen ist abzusehen) auf die Bildung des Kapholländischen übrig. (...) Es fragt sich, ob die kreolische Färbung, welche das Kapholländische trägt, auf Rechnung des Hottentottischen zu setzen ist.'
} 
speakers of Afrikaans, it felt as if the status of language has been degraded when formed under the influence of a slave language. No wonder that the Dutchman C.J. van Rijn, who taught in Cape Town, where he published a series of Dutch and Afrikaans school books from the turn of the century, including a reading method that claimed to be the first in South African based on the 'home language, the spoken language', ${ }^{51}$ heavily protested against the suggestion that Afrikaans was a product of language mixing, in a pamphlet-like booklet intended for teachers, ministers, and interested parties, in which he studied the close relationship between Dutch and Afrikaans.

Afrikaans is not a bastard, babble or mixed language. (...) Your language has been preserved as a miracle, despite the browns that shattered it, despite lack of education, despite "a century of injustice". (...) Afrikaans is Dutch through and through (1914: 75). ${ }^{52}$

This aversion to a possible coloured influence was so common in South Africa that it should come as no surprise that the first study on the history of Afrikaans, Viljoen's 1896 Strasbourg dissertation, comes to the conclusion that the phonetic system of the language is based on spoken North-Holland, thus Dutch, dialects, which he calls Volksprache Nordhollands, even though he accepts a certain influence of the white European languages French and German (Viljoen: 1896: 58).

It was not only Afrikaners who could not accept a coloured or slave influence, the Dutch linguist Cornelis Stoffel (1882) and the Amsterdam professor of Dutch literature and Linguistics Jan te Winkel (1896) shared the opinion of Matthias de Vries and argued that it was the Huguenots who influenced the formation of Afrikaans (Noordegraaf 2014: 527).

\subsection{The denial of language mixing}

The question raised by Hahn whether Afrikaans was a 'Teutonic', thus European, or a Hottentot language, continued to dominate the debate about the origin of Afrikaans. Two schools faced each other in this often heated discussion. The first group of scholars defended the European, West-Germanic, character of Afrikaans, whereas the other stressed the Creole features of the language. Within the first group, a distinction can be made between those who see the history of Afrikaans as nothing more than a spontaneous development from Dutch and Dutch dialects of the

\footnotetext{
${ }^{51}$ https://www.worldcat.org/search?q=au\%3ARijn\%2C + C. + J. + van\%2C\&dblist=638\&fq=yr\%3A1 900\&qt=facet_yr\%3A (retrieved 15.03.2021)

52 'Het Afrikaans is geen bastaard-, brabbel- of mengtaal. (...) Uw taal is als een mirakel bewaard gebleven, ondanks de bruinen die haar radbraakten, ondanks gebrek aan onderwijs, ondanks "een eeuw van onrecht". (...) Het Afrikaans is door en door Hollands.'
} 
$17^{\text {th }}$ century into Afrikaans ${ }^{53}$ and scholars who attribute changes to the problems that second language learners at the Cape encountered while mastering Dutch. These second language learners included Khoekhoe and Malay or Creole-Portuguese speaking slaves in addition to French and Germans. However, the emphasis was on the European immigrants as they mixed with the Dutch-speaking whites. Eurocentric theories were favored, since mixed languages or better, Creole languages, were not highly regarded around $1900 .^{54}$

[T] he Zeitgeist generally favored a purist attitude towards both linguistic and racial matters, and creolization was equated with miscegenation, both being regarded as deviations from the norm by linguists and laymen alike. The Newgrammarian approach to linguistic description, based on the Stammbaumtheorie (or Family Tree Theory), relegated what were regarded as mixed languages to the position of "black sheep of the family", or illegitimate children, because the accepted line of descent was one parent per child (...). Racialist attitudes characterized the investigation of the origin and history of languages $(\ldots)$ (Kotzé 2005).

The Dutch linguist Dirk C. Hesseling had to experience this hostility when he proposed a theory that attributed an important place to a slave language in the development of Afrikaans. Hesseling was a specialist in Modern Greek and had been concerned with the question of how Modern Greek had developed: straight from Attic or from a mixture of different languages and dialects (Noordegraaf 2014: 527). After he had become acquainted with the ideas of Schuchardt and with Schuchardt himself, he dared to ask similar questions with regard to the origin of Afrikaans ${ }^{55}$ and

${ }^{53}$ According to Markey (1982: 169), the Dutch dialectologist Kloeke, who published a monograph about the origin and growth of Afrikaans (1950), is the representative par excellence of a most strict spontaneous evolution theory. This school 'lauds "the miracle of Afrikaans", denies linguistic miscegenation, and is exclusively Eurocentric: it represents the politically-tinged party line of white supremacy.' Kloeke argued he could designate a South Holland founder's dialect for Afrikaans on the basis of dialect agreements. His work was not well received in South Africa and especially the doyen of the 'philological school' Scholtz (see 4.5) heavily criticized Kloeke's work, especially his analyses of diminutive formation in Afrikaans and in the dialects of the province of South-Holland (Scholtz 1950, reprinted in Scholtz 1963: 232-256; see also Den Besten 2005). Although Markey presents Kloeke as a symbol of scholars who worked from a belief of white supremacy, Kloeke (1950: 213-214) made an open plea for the equal rights, also linguistically, for coloured Afrikaans. He also questioned whether the characteristics and developments of coloured Afrikaans are indeed secondary to white Afrikaans.

${ }^{54}$ The discussion on the origin of Afrikaans has been described by many authors, among others by Smith (1927), Barnouw (1934), Nienaber (1949 and 1953), Smith (1952), Boshoff and Nienaber (1967), Zimmer (1992), Ponelis (1993), Roberge (1990, 1994 and 2002), Holm (2000: 27-29), Kotzé (2005), Hinskens (2009), Bergerson (2011), Grebe (2012), Conradie and Groenewald (2017), Carstens and Raidt (2017), Kriel (2018) and Groenewald (2019). Kotzé and Kirsten (2016) discuss the views on the origin of Afrikaans from three different schools of linguistic thought and their relation to nationalistic purism.

${ }^{55}$ Roberge (2006: 2401) calls him the first linguist 'to bring out an extensive study of the origins of Afrikaans.' 
afterwards also the Negro-Dutch of the Virgin Islands. After a first publication in 1897 Hesseling published a detailed monograph about the 'history of the Dutch language in South-Africa, in which he stressed the 'hyper-analytical' character of Afrikaans. $^{56}$

If only in our century we could point out examples of a language that so much distinguishes itself from Dutch by its hyperanalytic character, we would already have difficulty in believing that the spontaneous development of any Dutch dialect could be envisaged here. It is not easy to point out an example that the language of a colony deviates to such an extent from the linguistic forms of the mother tongue in the course of two centuries apart from the influence of a foreign idiom (Hesseling 1899: 11). ${ }^{57}$

Hesseling discussed all possible foreign idioms that may have influenced Afrikaans. Since he thought that the contact between the colonist and the Hottentots was much more restricted than with their slaves, it must have been the languages of the slaves which caused the language 'simplifications'. Afrikaans, however, did not completely creolize due to inhibiting and neutralizing factors such as the constant arrival of fresh Dutch speakers from the Netherlands, the influence of the Dutch bureaucracy and administration, of the Dutch speaking pastors who often came directly from the Netherlands, and of the Bible, translated in a sort of standardized Dutch (Grebe 2012: 16). Afrikaans stopped half way on its development to become a Creole language (Hesseling 19232: 128). Since Hesseling followed Schuchardt who reported about a Malay-Portuguese Creole found in Batavia (Java, Indonesia) (1890), he incorrectly believed in a combined lingua franca of Bazaar Malay and Portuguese Creole (Van der Wouden 2012: 291-300). But it was not because of this mistake, that would only be criticized much later, that Hesseling's theory encountered much opposition. Barnouw (1934: 21) summarized the reception of Hesseling's theory.

Dr. Hesseling's theory is not popular in South Africa. It is felt to put a stigma on the race of the Voortrekkers and on their language, and Afrikaans scholars, foremost among whom are Professor D.B. Bosman, Professor Smith, and Dr. S.P.E. Boshoff, have done their best to refute it by tracing the peculiarities of the Taal [Language] back to certain peasant dialects of Holland.

\footnotetext{
${ }^{56}$ Unlike Dutch, Afrikaans has no grammatical gender and thus only one definite article. Afrikaans shows deflexion, the same form is used for infinitives of verbs and present tense. Afrikaans dropped the simple past tense, except for a few exceptions. Afrikaans has only one auxiliary to form the present perfect, whereas Dutch distinguishes between verbs with zijn 'be' and hebben 'have'; there is a coincidence of demonstratives and interrogative pronouns in Afrikaans etc.

57 'Indien we eerst in onze eeuw staaltjes konden aanwijzen van een taal, die zóo zeer door haar hyperanalytisch karakter zich onderscheidt van het Nederlandsch, zouden we reeds moeite hebben te gelooven dat hier aan de spontane ontwikkeling van eenig Nederlandsch dialect kan worden gedacht. Niet licht zal men een voorbeeld kunnen aanwijzen dat, buiten den invloed van een vreemd idioom, de taal eener kolonie in den tijd van twee eeuwen in die mate afwijkt van de taalvormen der moedertaal.'
} 
Reinecke (1975: 322-323) rightly concludes that it is not the Creole-like simplification of Afrikaans, which is felt offensive by the white Afrikaans speaking community of linguists, 'but the word Creole with its smack of color, ${ }^{58}$ C.J. van Rijn, the Dutch schoolmaster living in Cape Town introduced in section 4.1., joined in the discussion with catchphrases on the back cover of his booklet for teachers and ministers (1914):

What is Afrikaans? Is it a Mixed language? A Bastard language? Oh no. NOTHING of it! Is it Dutch? In heart and soul. Does Malay-Portuguese have anything to do with it? Nothing at all. ${ }^{59,60}$

On the same back cover Van Rijn calls on its readers to discuss these questions in their debating clubs and to use the arguments he has put forward against the MalayPortuguese hypothesis. The opposition against Hesseling was not limited to South Africa. The German linguist, early anti-Nazi, and specialist in mystical movements Heinrich Meyer-Benfey (1901: 10-18) was the first one to oppose Hesseling's theory in his grammar of Afrikaans. According to Meyer-Benfey the influence of the slaves on the Dutch language was limited, since 'the bearers of the language' were and remained the original Dutch speakers, who cultivated and cared for their language, even though he pointed to the broken-Dutch of the Hottentots who picked up Dutch as a foreign language and transmitted that language to the next generations. Also Etsko Kruisinga, a Dutch specialist in English and prolific writer on linguistic matters, criticized Hesseling.

Dr. Hesseling thought of the influence of Malay-Portuguese, which was spoken in the coastal towns by the slaves imported from various parts of Africa, as well as by the whites. But according to H. himself, the slaves learned Dutch soon after their arrival, and this was promoted by the government. That makes a significant influence of the slave language unlikely (Kruisinga 1906: 418). ${ }^{61}$

Kruisinga claims to have shown that all the data and examples Hesseling adduces to support his theory could be the result of an independent internal development of Dutch (1906: 426).

Hesseling only found support in a Ghent dissertation by the Afrikaner linguist Pieter du Toit (1905) and in a series of articles by the Dutch specialist in

\footnotetext{
${ }^{58}$ Markey (1982: 169) must establish that this view 'has met with general hostility.'

59 'Wat is Afrikaans? Is het een Mengeltaal? Een Bastaardtaal? O, Neen. NIETS daarvan!

Is het Hollands? In hart en nieren. Heeft het Maleis-Portugees er iets mee te doen? Glad niks.'

${ }^{60}$ Note that Van Rijn claimed to write Dutch. His exclamation 'glad niks', however is Afrikaans and is not known in Dutch, where it should have been helemaal niets.

${ }^{61}$ 'Dr. Hesseling heeft gedacht aan invloed van het Maleis-Portugees, dat op de kustplaatsen gesproken werd door de slaven die uit verschillende delen van Afrika werden ingevoerd, en ook door de blanken. Maar volgens H. zelf leerden de slaven, al spoedig na hun aankomst, Hollands, en werd dit door de regering bevorderd. Dat maakt grote invloed van de slaventaal niet waarschijnlijker.'
} 
old-Germanic, Arie Bouman, who taught in South-Africa for many years. In an article about the Afrikaans double or brace negation (1923) Bouman pointed to a possible influence of Bantu languages next to a phonological explanation. Bouman (1924) he supported his argument with a few examples of the early slave lingua franca (see section 3.2.). Some years later he wrote

In the field of Afrikaner linguistic history, one will also have to revise the term "spontaneous development" more and more with reserve, which borders on mistrust. (Bouman 1928: 41). ${ }^{62}$

The rest of the Dutch and Afrikaner academic world still stuck with the old idea of white supremacy, also in linguistics. The history and fate of the thesis of the young Afrikaner Theo Schonken provides a strange but striking example of the negative attitude towards Hesseling's Creole theory. F. Theo(philus) Schonken (1879-1909) was a young Afrikaner scholar who was interested in folk traditions. After his studies in the Netherlands he went to Leipzig, where he prepared a doctoral dissertation under the supervision of Eugen Mogk, professor of Scandinavian philology. Before he could defend his thesis, he passed away. His study, however, was published in 1910 as a supplement to the Internationales Archiv für Ethnographie under the title Die Wurzeln der Kapholländischen Volksüberlieferungen. His Dutch friends, being interested in Afrikaner culture, wanted the book to be translated into Dutch. When doing so and when comparing the printed text with the manuscript, they noticed that a whole paragraph about the Afrikaner language was omitted, due to an intervention of Eduard Sievers himself (Schonken 1914: X). According to the neogrammarian Sievers this part was not to be included since it enthält viel Anfechtbares 'it contains much which is contestable'.

In the Dutch edition (1914) this paragraph is included and starts:

Dr. Hesseling has informed us in detail about the close relations of the indigenous African people with the slaves of the Indies and about their influence on the language. Because they, together with the exiled Malays [people from now Indonesia who were sent in exile to South Africa by the Dutch colonial government $\mathrm{CH}$ ], soon formed a sizable element of the Cape, which was in constant communication with the Dutch, the language of the European colonists adapted to their Creole language forms, thus determining the present form of Afrikaans, while many bastard words from their common language, Malay-Portuguese, invaded (Schonken 1914: 158). ${ }^{63}$

62 '[M]en [zal] ook op het terrein van de Afrikaanse taalgeschiedenis de term 'spontane ontwikkeling' meer en meer met reserve, die grenst aan wantrouwen, moeten herzien.'

${ }^{63}$ 'Dr. Hesseling heeft ons uitvoerig op de nauwe betrekkingen der Afrikaners tot de uit Indië stammende slaven en over hun invloed op de taal ingelicht. Doordat zij te zamen met de verbannen Maleiers weldra een talrijk element aan de Kaap vormden, dat in gestadig verkeer met de Hollanders stond, heeft de taal der Europeesche kolonisten zich aan hun kreoolsche taalvormen aangepast, waardoor de tegenwoordige gedaante van het Afrikaansch bepaald werd, terwijl vele bastaardwoorden uit de hun gemeenzame taal, het Maleisch-Portugees binnendrongen.' 
Subsequently, Schonken presents ample examples of words from everyday life that originate in Malay. When he comes to the phonology of Afrikaans, Schonken refers to Hesseling and Schuchardt (1914: 167$)^{64}$ and regularly points to phonological parallels between Malay and Afrikaans and to possible Malay influence on the Afrikaans pronunciation.

The aversion to or better, dislike, of Hesseling's theory thus arose both from scientific animosity between linguistic schools and from national, racist pride. The ruling neogrammarian views and overlying social feelings went hand in hand to defend a Eurocentric position. The urge from the rest of the world to the Afrikaners to also provide space for a non-white influence on the origin of their language, and society, was therefore very limited.

How the Afrikaner cultural and intellectual world actually thought about their language is best expressed in the often quoted words of the poet-politician and language activist Cornelis J. Langenhoven in an address to the South African Academy for Language, Letters and Arts in 1914 in Bloemfontein Afrikaans as voertaal 'Afrikaans as language of communication':

[Th]is our most precious fame, our highest possession: the only white man's language made in South Africa and not brought over the sea in completed condition (Kannemeyer $\left.1996^{2}: 331\right)^{65}$

\subsection{Against a Malay-Portuguese influence}

Although a scholar like Kruisinga (1906) used linguistic arguments to challenge Hesseling's theory, most of his opponents simply stated that his view was wrong and that a single ancestor theory had to be correct for Afrikaans. Jacobus J. Le Roux (1921: 3), for instance, started his introduction to Afrikaans for Dutchmen with a statement

First and foremost, it has been stated that Afrikaans is essentially the same language as Dutch, from which it originated since the seventeenth century. ${ }^{66}$

The first scholar who seriously disputed Hesseling's Creole views, Daniël B. Bosman, accepted a certain but small influence of the slaves' lingua franca but in fact defended the theory that Afrikaans was an extraterritorial variety of Dutch.

${ }^{64}$ The tension between Schuchardt and the Neogrammarians is a well-known fact in the world of linguistics. Think only of Schuchardt's Über die Lautgesetze. Gegen die Junggrammatiker (1885) 'About the sound laws. Against the neogrammarians.'

65 '[D]is ons kostelikste roem, ons hoogste besitting: die één enigste witmanstaal wat in Suid-Afrika gemaak is en nie oor die seewater klaar gekom.'

${ }^{66}$ 'Voorop is gesteld, dat het Afrikaans in de kern dezelfde taal is als ' $t$ Nederlands, waaruit ' $t$ sedert de zeventiende eeuw gesproten is.' 
Bosman (1916 and 1923) checked the muster-roll of the VOC ships and found that most of the sailors were Dutch. He found that 1,500 vessels moored in the first forty years of the refreshment station. More than 1,300 of this number were Dutch and only four ships a year arrived in Table Bay with a crew that spoke broken Portuguese. Therefore the influence of a sailors' lingua franca should be excluded. In addition, most of the slaves who were brought to the Cape till 1677 came from Africa, which implies that they did not speak Malay. Moreover the number of slaves from Malay speaking regions remained very little till 1715 . After all, the number of colonists exceeded the number of slaves till the beginning of the $18^{\text {th }}$ century. Therefore, it is very unlikely that there was a an influence from the slaves on the colonists in the first decades of the colony, a period essential for the emergence of the new language variety, he supposes.

Bosman (19282: 53) criticizes the selective way Hesseling used sources and, as he puts it in his preface, that is why he cannot escape being polemic (1923: 3). Hesseling's 'theory has many followers, at least in the Netherlands, and so he had to fight it and defend his own vision'. Bosman's own hypothesis is that Afrikaans is a direct daughter of Dutch.

Insofar as Afrikaans is not the spontaneous development of Dutch, it is a development of Dutch mainly under the influence of the Dutch of foreigners (Bosman 1923: 100-101). ${ }^{67}$

This means that scholars who come across phenomena in Afrikaans which differ from Dutch first of all have to look into historical and dialectal data from Dutch to find out whether this phenomenon could not have developed spontaneously from Dutch. If not, one may turn to interlingual transfer (Grebe 2012: 17) from the language of foreign speakers whose mother tongue could be a European language, a slave lingua franca, or the language of the Khoekhoen. Attempts by non-Dutch speakers to speak Dutch lead to simplifications (Carstens and Raidt 2017: 430). More than 60 years later Ponelis (1991 and 1993) again defended the important role the Dutch of foreigners played in the changes from Dutch to Afrikaans. Ponelis (1991: 192), however, accepts the term creolization for this influence.

Bosman (see section 3.7) has been criticized by Boshoff for not being racist enough when he accepted the possibility of a common language of slave children and their white playmates and peers. Bosman (1916: 39-40) however, denied that this should automatically lead to a mixed adult language.

A fact that has so far received too little mention in the writings on Afrikaans is that a white man who is aware of his superiority does not so readily take over a word from a slave or young man standing below him, except when he is in conversation with the slave or young himself. (...) Most whites, fathers, mothers, and children (in the East of

67 'In sover as Afrikaans nie die spontane ontwikkeling van Hollands is nie, is dit ' $n$ ontwikkeling van Hollands hoofsakelik onder invloed van die Nederlands van vreemdelinge.' 
the Orange Free State) know Sesotho and speak it to their [servant $\mathrm{CH}$ ] people on a daily basis. It often happens that children up to their fifth or sixth year, can speak Sesotho better than Afrikaans, sometimes exclusively Sesotho, and yet in the fifty years (which this situation exists), no mixed language, or anything similar, arises. ${ }^{68}$

Hesseling's remark that social distinctions hardly play a role in the emergence of Creole languages, as can be shown in the case of Negro-Dutch (Hesseling 1905: 54), did not convince Bosman. The social stratification in South Africa is different (Bosman 19282: 118). In addition, Creole influences are only found in coloured Afrikaans, which is not suiwer Afrikaans 'proper Afrikaans' (Bosman 19282: 80).

Boshoff (1921) followed Bosman in his dislike of Hesseling's theory and in his claim that most of the phenomena of Afrikaans which seem to differ from Dutch can be explained as a result of spontaneous developments originating in Dutch. Boshoff did not share, however, the second part of Bosman's claim. According to him, there is no need to enlist the help of Dutch-learning foreigners to explain apparent particulars. The background of the Dutch and other European settlers was rather diverse. Therefore they had to equalize their language. Boshoff uses the German term Ausgleich 'equalization' for this process (Boshoff 1921: 34). Nevertheless, many different forms remained active. Unlike Dutch, where a relatively homogeneous starting point formed the basis for the development of the national language, this was not the case for Afrikaans. Boshoff followed the theory of the dilettante linguist and language activist reverend Willem Postma (1912: 594) and stressed the role of the language-learning Afrikaner child (Boshoff 1921: 77).

(1) Afrikaans is the language of the Afrikaans child, born of Dutch parents and surrounded by different kinds of people, who spoke a different language than him.

(2) The material, which the Afrikaans child used for language formation, is Dutch of the $17^{\text {th }}$ century as it lived in the vernacular.

(3) Dutch became Afrikaans in the mouth of the Afrikaans child, because he had to adapt his language to the circumstances, in which he was born and grew up. ${ }^{69}$

68 „n Feit wat tot nog toe in die geskrifte oor Afrikaans te weinig vermelding gevind het, is dat die sig van superioriteit bewuste blanke, nie so geredlik " $n$ woord van " $n$ slaaf of jong wat beneden hom staan oorneem nie, behalve wanneer hy in gesprek is met die slaaf of jong self. (...) Die meeste blanke, vaders, moeders en kinders (in die Ooste van die Oranje-Vrijstaat), ken Sesoetoe en praat die daagliks met hulle volk. Dit kom dikwels voor dat kindertjies tot hulle vyfde of sesde jaar, beter Sesoetoe as Afrikaans kan praat, soms uitsluitend Sesoetoe, en tog is daar in die vyftig jaar (wat dié toestand bestaan), geen mengeltaal, of iets wat daarop lyk, ontstaan nie.'.

69 '(1) Afrikaans is die taal van die Afrikaanse kind, gebore uit Hollandse ouers en omgewe van verskillende soorte mense, wat ' $n$ ander taal gepraat het als hy.

(2) Die materiaal, wat die Afrikaanse kind gebruik het vir taalvorming, is Hollands van die I7e eeu soals dit geleef het in die volksmond.

(3) Hollands het in die mond van die Afrikaanse kind Afrikaans geworde, omdat hy sy taal moes aanpas aan die omstandigbede, waarin by gebore was en groot geworde het.' 
To show how Afrikaans lexical items could be traced back to Dutch, Boshoff took a sample of 2,000 words from three spheres of use, heritage, own property, and borrowed culture, and demonstrated how they could be etymologized in different languages, but especially different Dutch dialects. This research became the starting point of Boshoff's successful career as the most esteemed etymologist of Afrikaans.

Boshoff remained skeptical about Creole explanations of Afrikaans developments, especially about the Malay-Portuguese theory, till his last publication. Referring to the revival of Creole explanations by Valkhoff, he polemically wrote in the introduction to the etymological dictionary by Bosman and Nienaber (1967: 25) that 'the old wandering spirit of Malay Portuguese has not yet been conjured up' and 'and is taken from the grave from time to time, with or without the help of a magic potion or a clown'.

A third opponent against Hesseling's Malay-Portuguese hypothesis was Johannes Smith, who voiced his objections for the first time in 1913 (Slomanson 1993: 421), again in 1927 but made them widely heard with his 1948 lecture, published posthumously in 1952. At first glance, his argument looks terminological; an ideological racist undertone, however, cannot be denied.

(...) I wish to point that when people speak of the process of creolizing in connection with Afrikaans, something totally different is intended from what we mean when we use the term in connection with the usual Creole languages. A Creole idiom like PidginEnglish is a European language creolised in the speech of a native of Africa, Asia or America; but in the case of Afrikaans nobody can seriously maintain that it is a language that originated among slaves or Hottentots, and that the white colonists then exchanged their own speech for this idiom. All history flatly contradicts such a view (...) (Smith 1952: 11).

In this context, Smith explicitly targeted Pieter du Toit, whose 1905 dissertation was the only Afrikaans linguistic publication to support Hesseling's Malay-Portuguese theory. According to Smith, Afrikaans is a peasant dialect which rapidly developed into a language deviating from Dutch through a change of environment followed by isolation, but whose basis could be found in the Dutch dialects. Like Boshoff, Smith defends a monocausal theory of spontaneous origin.

In any case, there cannot be the slightest doubt that the Afrikaans population of South Africa and consequently the Afrikaans language originated in the country districts (Smith 1952: 15).

The Netherlandish colonists of South Africa came to a totally different sort of country, where the kind of farming practiced was unknown in the Netherlands. At an early date the agricultural and pastoral populations moved into the interior and got isolated not only from the European mother country but also from the South African mother city [Cape Town $\mathrm{CH}$.

(...) Is it then surprising to find that the language of the colonists changed very rapidly? 
Besides it should be remembered that the dropping of the flexion can be regularly explained, as in English, by the unchecked working of analogy and a few sound laws which were already to some extent found in the dialects of the Netherlands and Low Germany (...). It should not be forgotten that Afrikaans did not start from the modern standard Netherlandish, but from the popular dialects of the provinces of Holland, Zealand and Utrecht (Smith 1952: 16-17).

\subsection{Revival of Creole-Portuguese influence}

When Smith gave his lecture, Marius Valkhoff had already published his first study about the origin of Afrikaans seven years earlier. In this book he explicitly linked up with Hesseling (Valkhoff 1941: 90), even though he concentrated more on the influence of the Creole-Portuguese varieties of the slaves on the emergent Afrikaans. Valkhoff, a Dutch Romanist, was no stranger to South Africa, because he held chairs in the Netherlands and South Africa alternately. And his publication could hardly have escaped attention, because after a first edition in the Netherlands (1941), a second revised edition followed in 1943 in Belgium. Despite this, Smith does not mention him. Later African scholars also prefer to overlook his work. Johannes du Plessis Scholtz for instance wrote in the introduction to his 1980 book on the origin of Afrikaans:

I long doubted the desirability and necessity of including the two books of Marius F. Valkhoff [1966 and 1972] in the bibliography, its unscientific and offensive tone and also because there is nothing new of importance in it, at least not in support of an origin theory he wanted to breathe new life into. (Scholtz 1980: V). ${ }^{70}$

Valkhoff who polemically introduced the terms 'albocentrism' and 'diachronistic purism' for the ideological and linguistic stances of adversaries who supported a spontaneous development from Dutch to Afrikaans and accused them of racial prejudices realized that Afrikaners disliked the idea of a mixed origin of their language and of their group.

The Afrikaners themselves feel something demeaning in the Malay-Portuguese theory and from that I also explain its almost general rejection in South Africa, next to acceptance with us. However, I cannot justify that of them; that our common ancestors did not always live as saints, we have known for a long time! Different times, different customs, and both were somewhat rougher in the $17^{\text {th }}$ century than they are today. Nor is there anything despicable in an influence by Creole-

70 '[E]k het lank getwyfel oor die wenselikheid en noodsaak van die insluit in die bibliografie van die twee boeke van Marius F. Valkhoff [1966 and 1972], om die onwetenskaplike en aanstootgevende toon daarvan en ook omdat daar niks nuuts van belang in voorkom nie, althans nie ter ondersteuning van 'n onstaansteorie wat hy graag nuwe lewe wou inblaas nie.'. 
Portuguese; after all, it only means that a simplified form of a Romance cultural language, with some Malay and other Eastern words through it, has become spoken alongside Dutch and has acted on its structure. Besides, it is not about what is pleasant for the researcher or not, but what can be scientifically justified. (Valkhoff 1941: 96). ${ }^{71}$

Valkhoff, who also published in English, which made his views widely known, called Afrikaans 'a Netherlandic language that has undergone a beginning of creolization' (1941: 90). Also in this respect he followed Hesseling. Notwithstanding his international fame, his research has not survived time. Even scholars who themselves work within Creole theories indicate that the data on which he based his research was extremely weak.

The research in Valkhof 1972 is undeniable slapdash. (...) If nothing else in his work turns out to be of lasting value his insistence that the genesis of Afrikaans was subject to the continuum principle (that is, that we should speak of more or less 'advanced' forms of Afrikaans) ought to be a serious issue for anybody holding the view that language contact at the old Cape was more than random and unsystematic (Roberge 1990: 145-146).

Roberge (1986: 196) is somewhat more positive about Valkhoff's work:

[T] he value of Valkhoff's research lies not in its theory on the origins of Afrikaans but rather in its explicit recognition of a common heritage for the Afrikaans spoken by Whites and 'Coloureds'.

\subsection{The Philological School}

As shown, the polemics between adherents of 'spontaneous evolution' theories that dominated the discussion about the origin of Afrikaans much of the $20^{\text {th }}$ century (Willemse 2015-2016: 9) and proponents of Creole hypotheses kept the Afrikaans historical linguistic world busy for decades. It became more and more clear that all the views were untenable as long as they were not supported by hard linguistic data. That is why Johan Franken (see section 3.1) went into the archives in order to find older Cape Dutch data, surviving texts and testimonies about language use. Johannes du Plessis Scholtz (or du P. Scholtz) followed another path. He blamed the earlier

71 'De Afrikaners zelf voelen iets vernederend in de Maleis-Portugese theorie en daaruit verklaar ik ook haar vrijwel algemene verwerping in Zuid-Afrika, naast aanvaarding bij ons. Ik kan dat echter niet van hen wettigen; dat onze gemeenschappelijke voorouders niet altijd als heiligen geleefd hebben, wisten we toch al lang! Andere tijden, andere zeden, en beide waren in de $17^{\mathrm{e}}$ eeuw wat ruwer dan thans. In een beïnvloeding door Creools-Portugees ligt evenmin iets verachtelijks; immers het betekent slechts dat een vereenvoudigde vorm van een Romaanse cultuurtaal, met enige Maleise en andere Oosterse woorden erdoorheen, naast het Hollands gesproken is geworden en op de structuur daarvan ingewerkt heeft. Trouwens het gaat er niet om wat aangenaam voor den onderzoeker is of niet, maat wat wetenschappelijk te verantwoorden is.' 
theory builders for relying too much on sociohistorical data (Carstens and Raidt 2017: 427). The research program he advocated consisted of collecting and analyzing hard core linguistic data in older Dutch texts and Dutch dialects.

Scholtz introduced to Afrikaans historical linguistics a very rigorous inductive approach that explicitly precludes aprioristic theories of language genesis founded on external evidence: 'The emphasis now falls were it belongs: on the collection and evaluation of purely linguistic data, without conclusions being pressed into service in support of some preconceived theory that will in any event never "explain" the "origin" of the entire linguistic system (Scholtz 1980: 34; transl. Roberge 1992: 41). ${ }^{72}$

By following his own program and by attracting followers such as Roy Pheiffer, the young Gabriël Nienaber, and especially Edith H. Raidt, Scholtz founded what the Dutch generative linguist Hans den Besten (1985) called 'the philological school' in his review of a study by Raidt. Elsewhere (Den Besten 2000: 9) he calls this school theodiscocentric. $^{73}$ They claimed to be averse to any theory formation. As long as the facts were not clear, it was too early for hypotheses. It is not for nothing that he called the collection of 'his ground-breaking articles' (Groenewald 2019: 11) 'prestudies to the history of Afrikaans' (Scholtz 1963). Nevertheless 'Scholtz found it expedient to adduce from his empirical findings a synoptic explanation of the genesis' of Afrikaans in an otherwise unpublished lecture (Roberge 1992: 41). At the end of the $17^{\text {th }}$ century the language situation at the Cape was a mixture of different tongues such as Dutch, German, French, Khoekhoe, Bazaar Malay, Creole Portuguese.

Out of this melting-pot of languages an amalgam of them all could have arisen in which it would have been difficult to recognize any of the original components. But such a mixed language or bredie of languages did not, in fact arise; and if it had, it would not have resembled the Afrikaans we know to-day. Afrikaans is in its vocabulary and syntactical structure $99 \%$ pure Dutch (...). The differences are mainly grammatical - the still strongly flectional Dutch of the $17^{\text {th }}$ century having been driven towards deflexion - that is: along the same path as English was driven from Anglo-Saxon (Scholtz 1959: 4, quoted from Roberge 1992: 41).

'The preservation of the essentially Netherlandic character of Afrikaans was due to the fact that Dutch was the official language of the colony and had behind it the prestige of the VOC' (Roberge 1992: 42).

\footnotetext{
${ }^{72}$ Die nadruk val nou, soos dit hoort, op die versameling en bestudering van suiwer taalgegewens, sonder om die gevolgtrekking daaruit in diens te stel van " $n$ voorbarige teorie wat tog nooit die "ontstaan" van die hele taalsisteem kan "verklaar" nie.

${ }^{73}$ Den Besten (2000: 9 fn. 2) does not want to use Valkhoff's term albocentric or even the less offensive word Eurocentric, since these terms refer to the ideological background and not to the linguistic method. The alternative hollandocentric is not broad enough, since they also accepted Low German roots to explain Afrikaans phenomena. Theodiscus is the early Middle-Latin word for Continental WestGermanic. The 'Dutch' alternative is Diets.
} 
The method followed by 'the philological school' was to collect as many written Cape sources as possible and to compare the data from these texts with comparable data from the current and $17^{\text {th }}$ century Dutch vernacular and dialects. If it was possible to derive the Afrikaans data from any Dutch source no matter how far fetched, this was seen as a proof of the Dutch origin. Or as Den Besten (Van der Wouden 2012: 226) put it:

The South African Philological School certainly does not deny the existence of interference from other languages (nor does it deny the influence of 'broken Dutch'). Yet, its methodology could be rendered by the saying: "If it can be Dutch, it's got to be Dutch"where Dutch refers to any type of Dutch (early, modern, standard, nonstandard, dialectal). Thus, for the pertinent scholars superficial correspondences between structures in Dutch and structures in Afrikaans suffice as an argument for deriving these Afrikaans structures from Dutch.

How the analyses and monocausal explanations of the philological school worked will be shown in section 5 .

Since Scholtz and his school had a great aversion to theories, they never went into the ideological background of their method. Even though one must admit that much of their philological research is sound and is a fine example of value-free scholarship, one cannot escape the impression that their emphasis on Dutch descent was influenced by the Apartheid ideology of their time. After all, Roy Pheiffer (1979: 9) made it clear that the suggestion of a Creole influence should be avoided and that even the term Creole was anathema.

Theories of creolization or incipient creolization e.g. between Dutch and Malay or Malayo-Portuguese, propounded earlier, have proved to be unhelpful in giving a name to the change process which has come to light through meticulous and painstaking analyses of a large number of written sources. The features which modern creolists have identified as typical of the creolization process in general have brought some clarity on the point of a definition of the term itself, but there is still no general agreement.

To cut a long story short: some change processes appearing in the development of Afrikaans do resemble those encountered in true creolization, but then again, so many of the essential characteristics are lacking, such as drastic reduction in word forms and a brusque restructuring in the syntax, that other terminology becomes necessary.

Even though Edith Raidt was Scholtz's 'most important student' (Groenewald 2019: 15), she did not follow him in ignoring Valkhoff's work. She explicitly discussed Valkhoff's ideas in two publications (Raidt 1975 and 1977) and notices that his ideas are met with sympathy mainly by overseas non-specialists, due to political factors (Raidt 1983: 45). Although, she still followed the program of Scholtz, see for instance the title of her 1975 study 'Afrikaans and its European Past', the 'encounter with Valkhoff's ideas greatly influenced her own conception of the history of Afrikaans (...)' (Groenwewald 2019: 15). She remained opposed to the idea of a Creole 
influence on Afrikaans but accepted language interference as a possible factor causing changes. 'She started studying Afrikaans within the context of language contact something that Scholz never considered' (Groenewald 2019: 16). For example the way she explained the occurrence of the Afrikaans preposition vir plus direct object differs essentially from the way Scholtz did, as will be shown in section 5.2. In Raidt (1983: 184) she writes:

In contrast to many other Afrikaans peculiarities, there are no direct points of contact in the Dutch dialects of the $17^{\text {th }}$ and $18^{\text {th }}$ century. The connection comes from the CreolePortuguese trade language, which was commonly used in the $17^{\text {th }}, 18^{\text {th }}$ century among merchants and natives in the east of India. Dutch merchants of the East India Company were necessarily familiar with this commercial language, which explains why Jan van Riebeeck had already allowed such connections to slip through in his official 'Daghregister' 'daybook'. ${ }^{74}$

Raidt's more 'liberal' attitude towards possible influence of language contact on the development of Afrikaans does not imply a more positive evaluation of Creole hypotheses with regards to Afrikaans. The postscript of her 1983 monograph, in which she opposes a Creole explanation of Wh-movement in Afrikaans by Hans den Besten (1981), is that the most characteristic features for the development of a Creole language are missing in the history of Afrikaans. The emergence of Afrikaans took around 200 years (see also Raidt 1983: 118, 126, 159), whereas a pidgin normally pops up in 30 years. One does not find the abrupt and simultaneous structural changes typical for pidgins and Creoles.

Even though the final results of the Afrikaans language change often coincide with Creole characteristics, they were not caused by pidgin factors but by interference, as the study of the sources clearly shows (Raidt 1983: 191). ${ }^{75}$

\subsection{Afrikaans as a sister language of Dutch}

Even tough Scholtz and his pupils focused on data collecting instead of wild theorizing and although there gradually arose some appreciation for language con-

74 'Im Gegensatz zu vielen anderen afrikaansen Eigenheiten bestehen hier keine direkten Anknüpfungspunkte im dialektalen NDL. des 17. und 18. Jh. Die Verbindung stammt aus der kreol.port.Handelssprache, die im 17., 18. und 19. Jh. im ostindischen Raum bei Kaufleuten und Eingeborenen gebräuchlich war. Holl. Kaufleute der Ostindischen Kompanie waren mit dieser Handelssprache notwendigerweise vertraut, daher erklärt es sich auch, daß bereits Jan van Riebeeck in seinem offiziellen 'Daghregister' vereinzelt derartige Verbindungen durchschlüpfen ließ.'

${ }^{75}$ Obwohl die Endergebnisse des afr. Sprachwandels oft mit kreol. Kennzeichen übereinstimmen, wurden sie, wie aus dem Quellenstudium einwandfrei hervorgeht, nicht durch Pidgin-, sondern durch Interferenzfaktoren verursacht. 
tact as a possible cause for change, this did not end the mutual denunciation by representatives of creole theories and from the corner of the spontaneists. In particular Valkhoff and Hendrik J.J.M. van der Merwe stood opposite each other. Van der Merwe, who was head of the department of Afrikaans and Dutch at the University of South Africa, an institution for distance education, was a much sought-after radio speaker, editor of a widely read scientific journal, and editor/author of the most important university handbooks (Van der Merwe 1963, 1964 and 1968). His mud fight with Valkhoff, and over his head, also with Hesseling, therefore received more interest than it deserved in terms of content. From an ideological point of view, however, his remarks and 'extreme spontaneist' views (Roberge 1990: 145) are more interesting, the more since the focus of his activities was in the 1960s and 70s, the heydays of Apartheid.

Already in 1951, however, he summarized his view on the origin of Afrikaans in an Afrikaans language book for English speakers.

The linguistic point of view generally adopted today is that Van Riebeeck and his subordinates were not only speakers of the Dutch colloquial dialects, but that they also became, although unconsciously, exponents of the trends of these dialects, especially the tendencies towards deflection, substitution of the weak verb for the strong, levelling of all unnecessary linguistic ballast and discarding of linguistic encumbrances. No foreign language as such was responsible for this tremendous change of the old colloquial dialects and for their ultimate fusion into a new language; what was in progress in the old mother-country was simply carried out to the full in the new country with its new environment, requirements and topographical conditions. The same might have happened in the Netherlands if this process of "deterioration" had not been arrested by the deliberate establishment of a Standard language, which was furthered by the schools. (...) In South Africa the natural progress along the trends indicated above could not be halted as there were no schools at the beginning. By the time these were established the new language was already an accomplished fact. (...) If the commanders at the Fort and the early colonists did not bring about this change, i.e. at an early stage, how otherwise must one account for the remarkable uniformity of Afrikaans as it is encountered over so vast an area? (...) From the above it is clear that Afrikaans did not originate from present-day Dutch, but from the colloquial Dutch of the $17^{\text {th }}$ century, so that Afrikaans and Dutch must be regarded as sister-languages [italics $\mathrm{CH}$ ]. Afrikaans has retained its Germanic character to a far greater extent than English, which was changed tremendously under French influence, but even so retained so much of its Germanic heritage that anyone can easily detect the remarkable affinity between Afrikaans and English (Van der Merwe 1951: 21-22).

In an article which appeared after his death, Van der Merwe (1974: 33) again claimed that 'a general language was already far advanced in the Netherlands in 1652', a claim that has little support in Dutch historical linguistics. Van der Merwe claimed that both Dutch and Afrikaans developed in a normal way (1974: 33). 
Dutch, however, branched off to the left, to use an appropriate anti-communist metaphor of these Apartheid days. This happened, according to Van der Merwe, under the influence of a schooling system - compulsory education, however, did not start in the Netherlands before the end of the $19^{\text {th }}$ century. Afrikaans branched in a different direction, to the right, to continue the metaphor, where it could develop freely and follow a natural path. Van der Merwe's idea that Afrikaans and Dutch are sister languages is generally seen as bizarre.

The idea of accelerated drift in an extraterritorial setting reaches back to a long obsolete conception of language genesis (spontaneous development). As a scientific statement, it flies in the face of everything we know about the sociolinguistic context in which Afrikaans developed and about ordinary rates of linguistic change generally (...). Not surprisingly, van der Merwe's views were passed over in silence in Afrikaans historical linguistics (...) (Roberge 1992: 44).

Linguists may not have taken him seriously, but Van der Merwe was highly appreciated socio-politically. In 1966 he was invited on the basis of the cultural treaty between Belgium and South Africa for a three-month lecture tour through the Low Countries, during which he visited important universities and language centers (Neerlandia 1966, 70: 31). His denunciation of Hesseling - 'one time professor of New Greek, who never had been to South Africa' (Van der Merwe 1964: 70) - and the way he tried to ridicule Valkhoff's Creole Portuguese theory and Franken's data about sexual intercourse between whites and slaves ${ }^{76}$ may not have impressed his linguistic colleagues, but were very much in line with the predominant voice in the Afrikaner politico-linguistic debate of the time.

Moreover, Van der Merwe himself was convinced of the inescapability of the conclusions of his linguistic research, and perhaps given his popularity, so were the general public.

Whatever can be ascribed to our racial prejudice, one thing is very clear: our logical rejection of non-white influence in regard to Afrikaans rests on scientific facts and not on racial prejudice (1968: 29).

In 1951, however, Van der Merwe explicitly stated that 'unity of languages also suppose unity of race' (Van der Merwe 1951: 17).

76 'Apparently the drift of this is that fornication usually was accompanied by a dialogue in the language of the woman, for which everybody who indulged in these lusts therefore had to know Portuguese Creole, which have strongly promoted the Portuguese lingua franca at the Cape' (Van der Merwe 1969=1968: 33, quoted from Kotzé 2005, translation EFK). An additional argument against the possible influence of Malay-Portuguese-speaking slaves on the development of Afrikaans was that, according to Van der Merwe, the homogeneous group of Afrikaners who lived at the Cape Fort already left for the interior before the first slaves arrived (1961: 75). So they never met. 


\subsection{Afrikaans and Creole studies}

With the international rise of sociolinguistics and Creole studies, new accents emerged in the study of Afrikaans. Kotzé (1983) described variation in MalayAfrikaans. Nienaber (1994a) ${ }^{77}$ for example, accepted that there existed several varieties of Afrikaans next to each other. One of these varieties was KhoekhoeAfrikaans, which variety showed certain features of creolization and exhibited a range of similarities with later Afrikaans and therefore should be considered as part of the genesis of Afrikaans (1994: 139). In addition, Nienaber (1963) was one of the first to describe the Nama language in detail. And so he noticed, for example, a parallel between the Afrikaans brace negation and a more or less similar Nama construction, which became the starting point for Den Besten's analysis of the Afrikaans 'double negation and its relation with the genesis of Afrikaans' (Van der Wouden 2012: 221-256).

The variationist Van Rensburg (see 3.2) distinguished three varieties of Afrikaans, Orange River Afrikaans which was highly influenced by Khoekhoe, Frontier Afrikaans, which was the language of the Voortrekkers, the heroes of the Boerculture, and Cape Afrikaans, a variety that was highly influenced by the Malay and Creole Portuguese of the slaves (Van Rensburg 1997: 7). The Orange River Afrikaans and Cape Afrikaans may be described as aanleerdersvarieteite 'learner varieties' of Dutch, which is an interlanguage, a form of Dutch acquired, spoken, and transmitted to following generations by speakers of another mother tongue. Even Frontier Afrikaans did not remain pure Dutch, according to Van Rensburg. Due tot the cohabitation with Khoekhoe personnel, who used their own Khoekhoe-Frontier Afrikaans, this variety also got mixed (Van Rensburg 2012a: 147). Van Rensburg (2016: 457-459) agrees with Nienaber (1994a) and wants to call the Khoekhoepidgin that grew from the contacts of the Khoekhoen with Western European seafarers at the end of the $16^{\text {th }}$ century a learner variety with which the emergence of Afrikaans started.

\footnotetext{
${ }^{77}$ Nienaber's ideas about the character and origins of Afrikaans have changed greatly over time. He started out as a party member of Scholtz. In his 1949 book, he still called Afrikaans a white man's language, developed by the Afrikaner volk, and recreated in the mouths of whites, and not borrowed back from skew speakers (Kriel 2018: 144). Through his studies of Khoekhoe, however, and later also through the encounter with den Besten's work, Nienaber (1994a) realized his earlier work to be 'albocentric' and recognized the important place that should be attributed to the contribution of the Khoekhoen to the development of Afrikaans. Incidentally, the Werdegang [not a term in current English use; replace by development?] of Nienaber's view can be read well from the titles of his publications. While he still used the name Hottentot in the 1950s and 60s, from 1989 on he used the term Khoekhoe. Nienaber (1989b and 1994b) explains why Hottentot should be replaced by Khoekhoe. In Nienaber (1994a) he described the origin of Khoekhoe-Afrikaans. He then distinguished three varieties of Afrikaans, Burger-Afrikaans 'bourgeois Afrikaans', Khoekhoe-Afrikaans, and Malay-Afrikaans. For an overview of Nienaber's work see Grebe (2012: 20-28).
} 
The first non-impressionistic study of Afrikaans from a Creole background is by an American scholar, Thomas Markey (1982). Markey, specialist in Germanic languages, checked whether all eleven diagnostic features which classify a language as a Creole could be detected in Afrikaans. This turned out not to be the case. Afrikaans tested positively for only two features, with two other features being weakly present. The Negro Dutch from the Virgin Islands, however, tested positively for all eleven. 'Makhudu (1984: 3-4, 54-590 is rightly critical of Markey for having culled his information chiefly from a normative grammar of standard Afrikaans (...). His determination that 'coloured' Afrikaans and Flytaal [or Flaaitaal, an urban argot made up of Afrikaans and Bantu language(s) $\mathrm{CH}$ ] show significantly higher indices of creolicity provides a necessary corrective to the woefully incomplete picture that the unwary reader will adduce from Markey's article (...)' (Roberge 1994: 48).

At one level, Makhudu's general conclusion is entirely in line with current thinking among those who adopt the creolist perspective: 'It now seems likely that pidginization and creolization did indeed occur in the non-native Dutch communities of the early Cape'. Racial separation preserved creolisms in the 'coloured' community, while the Afrikaans of Europeans developed under the 'conserving influences of Dutch immigration and the promotion of the High or standard variety of Dutch until the early $20^{\text {th }}$ Century' (Makhudu 1984: 96-97, quoted from Roberge 1994: 48-49).

These and other observations brought Roberge (1994: 50) to the conclusion that Afrikaans 'will inevitably fall somewhere within the mid range of any reasonable scale of creolicity', a conclusion which is shared by the prominent members of the "Amsterdam School" of creolists ${ }^{78}$ (Holm 2012: 399), Muysken and Smith (1994: 5), who call Afrikaans a semi-Creole, or Den Besten, Muysken, and Smith (1994: 93) who prefer the term creoloid. ${ }^{79}$

Even though Den Besten explicitly defends Creole views on the origin of Afrikaans, just as Roberge and Deumert, one better calls his approach a convergence theory. Den Besten, who not only proposed a theory but also studied the sources of early Afrikaans and Khoekhoe, is convinced of a Khoekhoe influence on the devel-

\footnotetext{
${ }^{78}$ Holm (2012: 399) introduced this name in an article in which he appreciably discussed Den Besten's contribution to the research into the origins of Afrikaans after his early death. He even awarded Den Besten the honor of having this group of Afrikaans scholars 'evolved around him'. For the sake of completeness: it is perhaps no coincidence that this group of Creolists found fertile soil in the freethinker environment of Amsterdam in the 1970s. In any case, Amsterdam was a center of Dutch and European Anti-Apartheid activism in those years.

${ }^{79}$ Note that Reinecke (1937: 559) already called Afrikaans semi-creolized. Roberge (1994: 15) cannot hide his surprise when he sees how many different terms Afrikaans is classified with: rudimentary Creole, fusion Creole, acrolectal Creole, (non radical) fort Creole, in addition to creoloid and semiCreole. See Holm (2004) for a typology of partially restructured languages. About the classification of Afrikaans, see also Kotzé (2018).
} 
opment of Afrikaans in the early formative period. ${ }^{80}$ In a series of publications collected in Van der Wouden (2012) he gradually developed a model in which different varieties of pidginized and creolized Dutch merged.

As soon as European sailors met with the Khoekhoen at the Cape in the last decades of the $16^{\text {th }}$ century, the Khoekhoen created a trade jargon, a primitive pidgin, which was elaborated to a Dutch pidgin when the Dutch established their refreshment station at the Cape some 60 years later. The slaves who arrived at the Cape also had to develop a common means of communication, which also led to an, albeit different, Pidgin Dutch. These two pidgins merged due to mutual social contact and produced a first Creole Dutch around 1700, which he calls Proto Afrikaans I. VOC officials, settlers and sailors continued to speak Dutch. However, since they all came from different regions and backgrounds, their language showed a certain form of koineization and might be called Cape Dutch or Proto-Afrikaans II. ${ }^{81}$

In the second half of the $19^{\text {th }}$ century Creole Dutch and Cape Dutch converged, which led to an Afrikaans koine, in which there still existed dialectal differentiation. Due to the influence of the language engineers of the late $19^{\text {th }}$ and early $20^{\text {th }}$ century a Standard Afrikaans emerged alongside non-standard dialects. On the one hand the language activists chose a few phenomena from lower African dialects to accentuate the difference with Dutch, and on the other hand they sought a connection with Dutch, especially where the lexicon was concerned and when words or phenomena appeared to be missing in Afrikaans. Standardization of Afrikaans in fact was construction of Standard Afrikaans. This job lasted for almost fifty years and was done around $1930 .^{82}$

Even though the reception of Den Besten's theory in South Africa was initially highly critical - for instance Ponelis (1993: 33-34) blamed him 'that his position is based entirely on shaky linguistic evidence' and that he ignores 'socio-historical evidence' - now the belief dominates that he 'deserves high praise for having salvaged the Khoikhoi from where they were hidden under the umbrella term of "foreigners" and rightly argued for their significant contribution to the genesis of Afrikaans' (Groenewald 2019: 23).

\subsection{Afrikaans as a black language}

As has already been said in 2.5 the release from prison of the later president Nelson Mandela on 11 February 1990, was the starting point for major changes in

\footnotetext{
${ }^{80}$ The Afrikaans linguist Ponelis (1997: 608) who endorses language contact as one of the main as causes for the origin of Afrikaans doubts whether the Khoekhoen were tightly enough integrated to play such an important role.

${ }^{81}$ Ponelis (1993: 30) essentially subscribes to Den Besten's view: 'That there was a spectrum of creolization at the Cape follows from the logic within the multilingual Cape community. On the one hand, there was (spoken) matrilectal Dutch and on the other a whole range of interlectal varieties depending on closeness of contact. Afrikaans (...) is a continuation of an acrolectal variety.

${ }^{82}$ For an illuminating diagram of Den Besten's model see Van der Wouden (2012: 272).
} 
South Africa, also in terms of language policy and the status of the various languages. Apartheid came to an end and the new government aimed at equal rights for all people of South Africa regardless of colour, origin, and mother tongue and strove for reconciliation between the groups. Instead of being privileged, the white speakers of Afrikaans and their political and linguistic leaders turned out to speak one of eleven nationally recognized languages. In addition, they saw themselves confronted with two major language problems: Afrikaans was seen as the language of the oppressor, especially by black South Africans and the majority of Afrikaans speakers appeared to be non-white. These bruinmense ${ }^{83}$ lit. 'brown people', 'coloured' people, now had the same rights as the white speakers and started to claim their rights. The most heard solution, in addition to healing and reconciliation, is to accentuate the Creole character of Afrikaans and to even call it a black language, as will be shown.

Afrikaans is the third largest language of South Africa. It is the mother tongue of more than $13 \%$ of the population, which amounts to just under 7 million people. Of this total number of Afrikaans mother tongue speakers only 2,700,000 are whites. More than 3,500,000 are coloured, which is more than $50 \%$ of total number of the Afrikaans speakers. What is even more important: eighty percent of all coloureds in South Africa speak Afrikaans. ${ }^{84}$ Nevertheless, they still form a cultural minority among the speakers of Afrikaans. For example, ownership of the big Afrikaans media is still mainly white (Rawlings 2020).

In the process of standardization of Afrikaans the coloured varieties did not play a role. The language engineers of the GRA simply neglected or overlooked the existence of coloured Afrikaans speakers and their language (see section 3.3 and 3.5). Consequently Afrikaans did not meet the needs of half of the Afrikaans speaking population (Van Rensburg 1992: 187). Without the input of the indigenous Khoekhoe and imported African and Asian slave labor, however, there would have been no Afrikaans, as Den Besten (1987: 24-25) rightly states and Van Rensburg (2012) agrees with. The fact that the contribution of the Khoekhoen and the slaves was so important brings Webb and Kriel (2000: 22) to the conviction that linguists and language activists in fact appropriated Afrikaans from its rightful owners.

An ironic aspect of the Afrikaans language movement(s) was that the language was so totally appropriated by its white speakers: what was initially a language of the nonelite, the working class, black people, brown people, and uneducated white people, came to be regarded as the "exclusive" property of the white "elite" (despite, of course, of the fact that more than half of its speakers were not white).

\footnotetext{
${ }^{83}$ Michael le Cordeur (2015, a leader of the current coloured Afrikaans language movement argues that the term kleurling 'coloured' has so many negative political connotations that a new term had to be introduced. He suggested Afrikaans bruinmense.

${ }^{84}$ For more figures see Beukes (2004), Den Besten and Biberauer (2013), Van Sluijs (2013), and Carstens and Raidt (2019: 700-714),
} 
Kriel (2018: 132) calls Afrikaans a Creole, albeit an atypical one (2018: 142), that was hijacked by nationalists. ${ }^{85}$ It was a language invented by Khoekhoen and slaves out of their necessity for communication, but later on

the language has become the talisman of a narrow racist nationalism dedicated to the oppression of its real creators (Kriel 2018: 132 and 146).

Even though well-intentioned educators and linguists like Randall van den Heever (1987) attempted 'to establish an 'Alternative Afrikaans' movement, which was designed to serve the interests of the nonwhite speakers of Afrikaans' (Webb and Kriel 2000: 23), there remained a language-internal tension. Coloured Afrikaans speakers still feel squatters in their own language (Le Cordeur (2010b: 5). Therefore, linguists such as Van Rensburg (1992 and 1999) and Steyn (2014) advocate a repositioning of the Afrikaans standard. Maybe the only way out is a deformalization, de-standardization, or re-standardization as suggested by Stell (2010a, b), Van Keymeulen (2010), and Odendaal (2012 and 2014). The Cape-variety, Afrikaaps, has been frequently suggested as the Afrikaans of the future (Le Cordeur 2010a, Pearl 2021, Williams 2021).

The exclusion of colored speakers of Afrikaans is not the only problem that threatens the language. A perhaps even bigger problem is the aversion to Afrikaans among blacks, which is a consequence of the arrogance of the Apartheid regime that led to the riots in Soweto. Since the Soweto uprising was a result of the language demands of the Apartheid government (see section 2.5), the 'struggle' turned against the language. As Van Rensburg (1992: 185) explains it, it was a process of metaphorical transfer from the oppressors to the language of the oppressors. Language became the target of the aggression rather than those who speak the language. Consequently, the focus of that struggle for freedom turned against Afrikaans (Carstens and Raidt 2019: 640-652) and this was not only among the black pupils of the schools in Soweto but it became also the moment of truth for coloureds whose mother tongue was Afrikaans.

For many of us who speak Afrikaans, Afrikaans has been around us like water or like air for years - always present. Then June 1976 dawned. This was when pupils in the streets of Soweto held up posters and protested against Afrikaans as a language of instruction, and many were injured and killed in the days and weeks that followed. Posters such as "We do not want Afrikaans", "To hell with impurities: Afrikaans stinks!" "It was a day of recognition for us as Afrikaans speakers, a moment of revelation. In Derridaian terms, we would probably typify the moment as la rupture, "the break", the event. (...) The moment in which not only the nature of language as such is revealed, but also the associations of Afrikaans, our own connection, and even our sense of connectedness (Willemse 2019). ${ }^{86}$

\footnotetext{
${ }^{85}$ The only contribution of the white speakers of Afrikaans is the standardization and expansion of the language into a complete cultural and scientific language (Van Keymeulen 2018, 2019a: 84)

86 'Vir talle van ons wat Afrikaanssprekend is, was Afrikaans vir jare om ons soos water of soos lug, - altyd aanwesig. Toe breek Junie 1976 aan. Dit is toe leerlinge in die strate van Soweto plakkate
} 
Afrikaans became the symbol of Apartheid, the language of the oppressor (Webb 1997: 227) or as the white poet-artist and anti-Apartheid activist Breyten Breytenbach (2015: 16) called it Apartaans, a well-chosen blend of the words Apartheid and Afrikaans.

This language, Afrikaans, received equal rights in 1996. No wonder that it was approached negatively. In practice, Afrikaans did not lose so much of its speakers as of its status (Renders 2005: 13, Ideh and Onu 2017: 76, Van Keymeulen 2018) and ((semi-)public) domain (Roberge (2003: 33).

This resistance intensified and aggravated by black student actions in the years 2015-2017. The riots started as a protest against an increase in tuition fees, \#FeesMustFall, then spread to an attack on colonial symbols \#RhodesMustFall and finally resulted in an attack on Afrikaans as university language of instruction \#AfrikaansMustFall. The campaign along the campuses had the effect that even the most Afrikaans university, that of Stellenbosch, withdrew the primary rights for Afrikaans as a medium of education in 2016. An appeal to the Constitutional Court failed. The Court ruled that the previous language policy of the university advocating Afrikaans created an 'exclusionary hurdle specifically for black students'. Most white and coloured students were able to follow classes in Afrikaans, a minority of black students, however, were not, whereas all groups had sufficient command of English. ${ }^{87}$ Afrikaans-speaking coloured students started to object to the subordination of Afrikaans in April 2021. On 9 April, 2021, they went on strike in what they see as the start of the third Afrikaans Language Movement (T'Sjoen 2021). It was the first time of an organized coloured protest in South Africa. DAK ${ }^{88}$ Netwerk, the organization of coloured people in South Africa, joined the protest. Their president Danie van Wyk, a lawyer by training, posted a petition on the door of the academy building with the grievances of the colored people. The first is: 'recognize Afrikaans as an indigenous language.' Or in the words of Jean Oosthuizen (2021): Afrikaans is so unique to South Africa as fynbos and the quiver tree. ${ }^{89}$

The 2015-2017 campaign against Afrikaans not only caused much concern among white Afrikaans speakers, but also coloured speakers of Afrikaans felt left

omhoog gehou en betoog het teen Afrikaans as ' $n$ onderrigtaal, en talle in die dae en weke daarna beseer en gedood is. Plakkate soos "We don't want Afrikaans", "To hell with impurities: Afrikaans stinks!" Dit was ' $n$ dag van herkenning vir ons as Afrikaanssprekendes, 'n oomblik van openbaring. In Derridiaanse terme sou ons waarskynlik die moment typeer as la rupture, "die breuk", die gebeurtenis. (...) Die oomblik waarin nie net die aard van taal as sodanig ontbloot is nie, maar ook die assosiasies van Afrikaans, ons eie verbintenis en selfs ons sin van verbondenheid.'

${ }^{87} \mathrm{https}$ :/www.concourt.org.za/index.php/judgement/338-gelyke-kanse-and-others-v-chairperson-

of-the-senate-of-the-university-of-stellenbosch-and-others-cet311-17 (retrieved 10.10.2019)

${ }^{88}$ DAK is an acronym, consisting of the initials of the 16the century Khoekhoe leaders/interpreters Doman-Nomoa, Autshumao (Harry the Sandpiper), and Krotoa (Eva), see https://daknetwerk.com/ (retrieved 24.11.2020).

89 'Afrikaans is so eie aan Suid-Afrika soon fynbos en die kokerboom.' 
out in the cold. During Apartheid they were not white enough and now they were not black enough (Adhikari 2005 and Vlasblom 2017). Titus (2016: 189-190) accused the ANC government of a deliberate attempt to write brown South Africans out of history. Consequently, the coloured community and their white friends wanted to stress how active they have been in the struggle against Apartheid (Carstens and Raidt 2019: 595, 654) and that Afrikaans was not only 'the language of racists, oppressors and unreconstructed nationalists'(Willemse 2017) but also of resistance, that it was a 'battle language' (Plaatjies 2016: 87) a language 'of anti-imperialism, anti-colonialism, of an all embracing humanism and of anti-apartheid activism' (Willemse 2017).

In this context it will come as no surprise that Afrikaans was given the designation of a full creole language. Breyten Breytenbach called everyone in South Africa mixed, including the blacks, in terms of language, culture, and blood, and that is why Afrikaans is a Creole; his colleague poet Danie Marais (De Vries 2012: 137) did not need such a reservation. It is clear to him: Afrikaans is Creole. Hein Willemse (2015) not only followed him in this, in addition he identifies coloured South Africans with the blacks. Consequently, 'Afrikaans also has a black history', 'Afrikaans has a multifaceted nature, numerically dominated by its black speakers' and finally 'Afrikaans is more black than white'. Willemse is not alone, already in 1989 The New York Times published an article Blacks Shaped Language Of Apartheid, Linguists Say (Wren 1989). This form of appropriation of blackness and Creole looks as the opposite of the appropriation of Europeanness by Apartheid supporters and by defenders of spontaneous evolution theories. It looks like an answer to the title of the collection of poems by the anti-Apartheid poet Antje Krog Begging to be black (2010). Groenewald (2019: 24) contradicts the suggestion that the acceptance and popularization of Creole explanations is now due to 'a politically correct response to current realities'. ${ }^{90}$ It cannot be denied that Afrikaans has a Creole background.

[Afrikaans] originated at the Cape because the Dutch - not the English, not the Portuguese - settled at the Cape in the $17^{\text {th }}$ century, but today Afrikaans is spoken because of the influence of slaves and Khoikhoi who needed to learn this new language.

\section{Some examples of linguistic strife}

The discussion between the philological school that used good linguistic and philological craftmanship to implicitly prove a Eurocentric point of view and the

\footnotetext{
${ }^{90}$ Groenewald's view is not shared by everyone. The well-known journalist Leopold Scholtz complained in 2009 in the newspaper Die Burger that the now politically correct point of view is to say that Afrikaans comes largely from the languages of Khoi and slaves (Grebe 2012: 7).
} 
creolists who stressed the contribution of indigenous and slave languages to the origin of the new language, Afrikaans, revolved around several linguistic facts. One party tried to find Dutch or European data which could explain the phenomenon, the opposite party looked for Malay, (Creole) Portuguese, or Khoekhoe data to explain its origin. Three of these phenomena and the discussion about their origin will be summarized here briefly. These phenomena are:

- Substitution of the subject form of the personal pronoun of the first person plural by its object counterpart: ons

- vir followed by direct objects

- brace negation (double negation): nie...nie

\subsection{The convergence of ons}

In the first international publication on Afrikaans, Schuchardt (1885: 468) already noticed that there is something special about the personal pronoun first plural in Afrikaans compared to Dutch. In Dutch there exist two forms, wij as subject and ons as object. Afrikaans only has ons.

$\begin{array}{lll}\text { Dutch } & \text { Afrikaans } & \text { Gloss } \\ \text { Subject: wij lopen } & \text { ons stap } & \text { we walk } \\ \text { Object: zij zien ons } & \text { hulle sien ons } & \text { they see us }\end{array}$

Schuchardt was told, he reports, that this convergence was a result of French influence. After all, French only has one form: nous. Du Toit (1897: 30), the leader of the GRA, wrote in his comparative grammar of Afrikaans and English:

To the same source [the French of the Huguenots $\mathrm{CH}$ ] is to be traced the use of ons in Cape Dutch, where in Dutch wij and ons are used, being a regular version of the French nous-nous.

According to Hesseling (1899: 138) this explanation is highly unlikely, because the corresponding possessive pronoun in Afrikaans is also ons, whereas French makes a difference between the personal and possessive pronoun: nous versus notre and nos. He found, however, a parallel in Malay, where there is also no difference between the subject and the object form of this personal pronoun. The corresponding Malay form is kami, when the speaker excludes himself from the group, and kita when he includes himself.

Scholtz (1980: 68), one of the leaders of the then South African linguistic world, was not very happy with this suggestion. He claimed that the substitution of the subject form of a personal pronoun by the corresponding object form is a very common phenomenon in the history of languages and dialects. It is generally accepted, he stated, that the cause is a need to emphasize; and object forms are more suitable for emphasis. In the dialects of the two western provinces of Holland one does not 
find ons as subject, in the dialects of the South-Western province of Zealand, however, is has been attested. The probability of this explanation is limited, he admitted, since the influence of Zealand dialects on Afrikaans is rather small. ${ }^{91}$

Valkhoff (1966: 222) also discussed the ons case. He raised a number of questions related to the Zealand hypothesis.

Were there Zealand settlers at the old Cape who could have transmitted this feature? If so, were they numerous enough and did they have the opportunity of doing so? Well, then, among the first (104) free-burghers about whom we have records, there were five from Zealand and according to Bosman, who studied these and later figures, "it is clear that the Zealand influence should not be stressed too much" [Bosman 1922: 120]. Like the Flemings, they did not arrive all at once, but one by one, and do we know whether they all had slaves or Hottentot servants to whom they could have communicated their form ons? And, in case they did adopt it, would these servants have had such prestige among their countrymen or their comrades as to impose this trait? These are realities we have to face, instead of all the wishful Dutch etymologies proposed, as beautiful as they are unreal.

Valkhoff went on quoting Hesseling's Malay slaves proposal but he also added that there is another option: the Hottentots did not distinguish "between "we" and "us" and "our" in their languages either.

Am I deluding myself, or is what happened not more or less this? In the $17^{\text {th }}$ century the Hollanders had more success with their language at the Cape than in Ceylon [Sri Lanka] and in Batavia [Jakarta]. So both slaves and Hottentots learnt Dutch pretty soon, but they were not taught it in schools. Therefore they adapted the new language to their own linguistic habits as best they could, and the result was what any linguist outside South Africa would call "creolized speech" (Valkhoff 1966: 222-223).

Scholtz was convinced that the great changes in Afrikaans have taken place in the first decades after the landing at the Cape, therefore Hesseling's theory, that speakers of Malay had an influence on the convergence of ons, had to be dismissed as unlikely because there were hardly Malay people at the Cape before 1720. A Hottentot influence could be more plausible. After all, in Hottentots, as in Malay, French, and Portuguese, forms for object and subject are not distinguished in these cases. However, Scholtz did not want to give up a development from Dutch or at least from Germanic. In a language such as Afrikaans, which is so characterized by emphasis, this explanation remains very defensible, he stated.

Whoever is aware of the abundant examples of function changes among pronominal forms in Dutch vernacular, can hardly believe [italics $\mathrm{CH}$ ] that foreign influences in a similar phenomenon in the history of Dutch at the Cape are a decisive factor. ${ }^{92}$

${ }^{91}$ Scholtz (1963: 116) was still convinced that the change in the use of ons comes 'from the fatherland (sic!), maybe from Zealand where the use of ons is more emphatic than wij.' 
An extra argument for the Germanic background of the convergence of Dutch wij and ons in Afrikaans ons can be found in a Low German dialect, the Danish vernacular, and several English dialects, Scholtz adds in a footnote. Thus, he wants to believe in a spontaneous evolution from a Dutch or Germanic base.

Belief appears more often an argument in this discussion. Achmat Davids (2011: $60-61=1991)$, the father of Cape Malay studies,

find[s] it difficult to accept that these grammatical changes were copied from the colonist speaking a Dutch dialect. Firstly, I do not have any evidence of Cape Dutch sources indicating that wij was substituted by ons in the spoken language of the colonists at the time; secondly, if I were to agree with her [Raidt] I would have to ignore the fact that the Malayo-Polynesian grammar is remarkably simple and could have influenced this change. The use of ons for the Dutch subjective wij could be a reflection of the MalayoPolynesian grammar, which does not modify or change words by inflection to express case, number or gender. Hence the Eastern slaves were more likely to have applied a rule of grammar known to them and used one word, ons, for the pronoun "we", rather than two different words - wij and $o n z(\mathrm{e})$ - for a single concept.

Raidt (1983: 155-156), the grande dame of the philological school, hardly dealt with ons. She indicates that texts from 1672 on have been handed down in which ons appears as subject in the broken Dutch of slaves and Khoekhoe. Around 1735, ons as frequent but incorrect subject form already appeared to be a characteristic feature of the Boers. This data, however, did not bring her to conclude that ons originates in the language of the Khoekhoe or of the slaves.

The origin of ons instead of wij was often attributed to the broken linguistic usage of the Khoin and slaves and regarded as a pidgin mark or creolism. However, the use of ons as subject form instead of wij is an old dialect form that is still in use today, especially in Zealand. W.W. Schumacher [1973] pointed out that this nominative-accusative replacement is a case of "Germanic vulgarism", since exactly the same thing occurs today in Vulgar Danish and other Germanic languages; and something similar could be said of Vulgar English. It is therefore more than likely that ons in the subject function comes from the dialectal Dutch vernacular but was strengthened and spread at Cape through the influence of foreigners. ${ }^{93}$

${ }^{92}$ 'Wie bewus is van die oorvloedige voorbeelde van funksiewisseling onder pronominale vorme in Hollandse volkstaal, kan moeilik glo [italics $\mathrm{CH}$ ] dat vreemde invloede bij soortgelyke verskynsel in die geskiedenis van Hollands aan die Kaap 'n deurslaggewende faktor was.'

93 'Die Herkunft von ons statt wij wurde oft dem gebrochenen Sprachgebrauch der Khoin und Sklaven zugeschrieben und als Pidginkennzeichen oder Kreolismus betrachtet. Der subjektivistische Gebrauch von ons anstelle von wij is jedoch eine alte Dialektform, die heute vor allem in Zeeland noch gebräuchlich ist. W.W. Schumacher [1973] wies darauf hin, daß es sich bei diesem NominativAkkusativ-Ersatz um einen Fall von „Germanic vulgarism” handle, da genau dasselbe heute im Vulgärdänischen und anderen germ[anischen]. Sprachen vorkomme; und ein ähnliches könne vom Vulgärenglischen gesagt werden. Es ist daher mehr als warscheinlich, daß ons in Subjektfunktion aus der 
In Raidt (1976a: 111-113), she first presented several $17^{\text {th }}$ and early $18^{\text {th }}$ texts in which examples with ons can be found from the Hottentot language and from slaveDutch and then asked the question how ons as subject could be explained. Does it come form the Dutch of the colonists or is it due to the influence of Hotentots or slaves from the East? Her answer (1976a: 184) simply follows Scholtz (1963) and sticks to influence from Zealand. However, she suggests carefully that emphatic ons also was in use in the neigbouring dialects of Holland, albeit in 'uncivilized' varieties.

Even though Raidt is not the last one who wants to defend an origin from Zealand - the Dutch linguist Piet Paardekooper (1996) hints to parallel constructions in the dialects of Zealand and the Flemish speaking part of North France, so called French Flanders - the now most accepted explanation is that ons as subject form arose because new language learners abolished the subject-object distinction (Ponelis 1993: 27-30). It is, however, remarkable that ons as subject cannot be traced back to one of the Khoi languages. ${ }^{94}$ The explanation is that it is typical for a learner's variety to avoid morpheme differences (Van Rensburg 1996: 138 and 2015: 90). Subsequently, ons became an inherent part of Khoi-Dutch and Khoi-Afrikaans but it was seen as highly stigmatized (Ponelis 1993: 218). Later on ons as subject became destigmatized and established (Van Rensburg 2016). Or as Van de Glind (2016: 25) puts it: 'the emergence of ons as subject pronoun is largely due to innovations in the interlect of the Khoi speakers.'

\subsection{Vir + direct object}

One of the 'significant innovations' (Roberge 1994: 21) of Afrikaans is the use of vir, 'lit. for', before personal objects (hulle het vir my geslaan 'they beat me')' (Roberge 1994; 21). Also Hinskens (2009: 23-24) calls the ACP construction (accusativus cum praepositione) one of the more striking differences between Dutch and Afrikaans. 'In Afrikaans one can mark a direct object as an indirect object, while in Dutch it is excluded'.

Afrikaans: Ek het nie vir hom gesien nie

Dutch: $\quad *$ Ik heb aan hem niet gezien

Ik heb hem niet gezien

'I did not see him'

Schuchardt (1890: 226-227) already noticed in his study about a Creole spoken on Java that this type of construction is quite common in Malay, in Creole Portuguese and in Afrikaans.

\footnotetext{
dialektal-ndl [niederländischen] Umgangssprache stammt, anm Kap aber durch den Einfluß der Fremdlinge verstärkt und verbreitet wurde.'

${ }^{94}$ Analyzing an 1880 text, Luijks (2009: 157-158), however, suggests that accusative ons can be found realized in the Dutch canonical subject position on a calque of the syntax of Nama.
} 
What we see as a direct object in Malay is connected to the verb by a preposition in numerous cases, and this is also the case in our Creole. But not only in this, but in AsianPortuguese in general, yes, we encounter something corresponding far beyond it, and so the proportion that comes here to Malay cannot be determined with complete certainty for the time being. (...) Now there are also Creole dialects in which the accusative is equated with the dative, and both are expressed by the preposition 'for' (the dative use of which is very common; so in Thuringian: er sagte vor mich 'he said me'. So in the lingua franca (as it seems only in personal pronouns), for example respondir per mi, 'answer me', mi mirar perellu, 'I see him', mi gustar per ellu, 'I taste him' (namely the tea). So in Cape Dutch, e.g. ek geef ver jou wat mois, 'I shall give you something nice', sê jij ver die pêrd? 'Do you see the horse?'.

Hesseling (1899: 115-116) followed Schuchardt's suggestion and even puts forward an extra argument taken from the language of Dutch Jews. According to Hesseling and to his source, the dilettante linguist Taco de Beer, Dutch Jews may say je hebt aan mij vergeten and je hebt aan mij geslagen instead of standard Dutch je hebt mij vergeten 'you forgot me' and je hebt me geslagen 'you hit me'. De Beer and Hesseling associated this construction with the Spanish/Portuguese background of Dutch Sephardic Jews, since amo a Deus 'I love God' is perfect Portuguese. Hesseling also referred to Du Toit (1897: 13). Du Toit, who being a minister knew some Hebrew, found traces of Hebrew in Afrikaans.

Cape Dutch is similar to Hebrew in another respect, as both express the relation between a transitive verb and the objective noun by a particular preposition, for which we find no equivalent in either English or Dutch.

He gives as an example Gen. 4:1

$\begin{array}{lll}\text { Hebrew: } & \text { Ve ha adam jada } & \text { eth Hawa va teled eth Kajin } \\ \text { Afrikaans: } & \text { En die mens beken } & \text { fer Eva en sy baar fer Kaïn } \\ \text { English: } & \text { And the man knew } & \text { Eve and she bare Cain } \\ \text { Dutch: } & \text { En de mens(ch) bekende } & \text { Eva en zij baarde Kaïn }\end{array}$

Hesseling is not sure whether $\mathrm{Du}$ Toit wanted to claim a direct relation between Afrikaans and Hebrew - although this is not unlikely given the idea of the Afrikaner

95 'Im Malaiischen wird in zahlreichen Fällen das was wir als direktes Objekt ansehen, durch eine Präposition mit dem Verbum verbunden, und so auch in unserem Kreolisch. Aber nicht bloss in diesem, sondern im Asioportugiesischen überhaupt, ja Entsprechendes begegnet uns weit darüber hinaus, und so ist der Antheil der hier auf das Malaiische kommt, vorderhand nicht mit völliger Sicherheit zu bestimmen. (...) Nun gibt es auch kreolische Mundarten in denen der Akkusativ dem Dativ gleichgesetzt wird, und zwar Beide durch die Präposition 'für' ausgedrückt werden (deren dativische Verwendung ja sehr verbreitet ist; so thüring. er sagte vor mich. So in der Lingua franca (wie es scheint nur bei Personalpronominen), z. B. respondir per mi, 'antworte mir', mi mirar perellu, 'ich sehe ihn', mi gustar per ellu, 'ich koste ihn' (näml. den Thee). So im Kapholländischen, z. B. ek geef ver jou wat mois, 'ich gebe Ihnen was Schönes', sê jij ver die pêrd? 'sehen Sie das Pferd?'.' 
nationalists that they were as much a chosen people as the Jews - but he considered it a support for the influence of a substrate language (Spanish/Portuguese) on the language of the Dutch Jews. Valkhoff (1966) remained rather silent on this construction. He only notices that vir cannot originate in High Portuguese since Portuguese uses $a$, not per/por (1966: 237).

The philological school ran into difficulties in explaining this phenomenon. The possibility of a Dutch origin, however, was not simply given up. Even though he quotes several examples from the $17^{\text {th }}$ and $18^{\text {th }}$ century, Scholtz (1980: 91-93) claims that vir in Afrikaans is a feature from the early $19^{\text {th }}$ century. He dismisses the early examples as utterances of foreigners or slaves, which means they cannot be considered Dutch or Afrikaans. Nevertheless, Scholtz does not have a real explanation for the innovation, the use of vir with a direct object.

The extensive use of for in Afrikaans has been explained in different ways. It has been pointed out that a measure of instability in the use of prepositions before the indirect object and also in the distinction between verbs that take a direct and an indirect personal object with them, existed in Dutch dialects from an early time, and that the instability would increase at the Cape where people from different places gathered and the Dutch language had to be learned by many foreigners (1980: 93). ${ }^{96}$

It is noteworthy that Scholtz who always produced an abundance of data from Dutch dialects to make his point now does not come up with any example of Dutch dialects which are instable in this respect. The other explanation Scholtz mentions is an influence of broken Portuguese or Malayo Portuguese. His final conclusion is that most likely all factors worked together and that a broken Portuguese construction may have enhanced and expanded an unstable Dutch dialectal use. Ponelis (1993: 271) appears to agree with Scholtz more or less and calls the use of vir an African innovation, however 'not entirely without a Germanic antecedent.'

Raidt (1976a: 194-195) starts with the remark that the construction does not occur in Dutch or in Dutch dialects. Possibly, the innovation comes from the influence of another language. There are several early examples from the broken Portuguese of slaves; however, since Van Riebeeck already used similar constructions one may think of a substitution effect. Maybe vir has taken the place of other prepositions. It is not unthinkable that one can find examples of such substitution in Dutch dialects. Her conclusion is that more research is needed. This she did herself and her results are published in a volume that was supposed to add luster to the unveiling of the

96 'Die uitgebreide gebruik van vir in Afrikaans is op verskillende maniere verklaar. Daar is op gewys dat " $n$ mate van onvastheid in die gebruik van voorzetsels voor die indirekte voorwerp en ook in die skeiding tussen werkwoorde wat 'n direkte en ' $n$ indirekte persoonlike voorwerp by hulle neem, van vroeg af aan in Nederlandse dialekte bestaan het, en dat die onvastheid groter sou word aan die Kaap waar mense uit verskillende oorde bijmekaar gekom het en die Nederlandse taal buitendien deur baie vreemdelinge moes aangeleer word.' 
language monument at Paarl (Raidt 1976b: 73-101). The conclusion of Raidt's research is that, based on new archival research, no leads can be found in Dutch dialects. The construction originates from Creole Portuguese. Raidt (1983: 184-187) emphasizes that Creole Portuguese was a trade language that was also used by traders who worked both in the East Indies and in South Africa. That is why Van Riebeeck's language already showed some instances of vir-constructions.

Carstens and Raidt (2017: 482-483) discusses the vir-innovation in relation to what they call taalversteuring 'language distortion' but what is called interference elsewhere. People whose mother tongue was a Creole Portuguese transferred the construction to the Dutch they wanted to acquire. In fact they explain the emergence of this construction as an innovation via an aanleerdersvarieteit 'learners variety'. How the whites subsequently took over this construction is not explained. Note that this explanation emphatically does not use creolization as cause for the innovation but assumes that it is the result of imperfect second language (L2) learning.

Den Besten studied this construction and its introduction into Afrikaans several times. In Den Besten (1977) he called it a hardly controversial issue. He compared the Afrikaans case marker vir, which may occur with animate direct and indirect objects, with Portuguese, Spanish and Italian $a$, and Malayo- and Asio-Portuguese Creole per and concluded that the basis must be found in a Malayo/Asio Portuguese system but this does not answer, he concludes, the question of how one grafts such a system onto Dutch or what one expects from the new system after it has been laid down over Dutch. Den Besten (2000 = Van der Wouden 2012: 313-331) discussed extensively the question as to which of the slaves' languages in the Dutch Cape could be the basis for vir. After having begun to point out once more that vir formally originates from the Dutch preposition voor 'for', he repeated that usually the syntactic explanation of the Afrikaans use of vir is sought in Asian Creole Portugese, especially in Indo-Portugese. Den Besten, however, wanted to defend that also Eastern Malay spoken by slaves from eastern Indonesia and their variety of Creole Portuguese may have been instrumental in shaping the use of Afrikaans vir. After all, in quite a number of the Eastern Malay languages object marking is in accordance with object marking in Indo-Portugese and Afrikaans. After a detailed study of the Cape Colonial slave population, their region of origin and the local Eastern Malay varieties they spoke, he came to the conclusion that

(...) it is probable that the syntax of Afrikaans vir ( $<$ Du voor 'for') has come about through various linguistic influences upon Dutch as spoken in the Cape Colony: on the one hand there was Indo-Portuguese (in cooperation with some of the native languages of the slaves from India-Sri-Lanka), on the other hand there were the Eastern Malay dialects as spoken by the majority of the slaves from Indonesia.

This explanation is not based on language learning problems as Carsten's and Raidt's (2017) proposal but is clearly based on language mixture, thus on creoliza- 
tion. Den Besten (2009 = Van der Wouden 2012: 355-373) summarized Den Besten (2000) and pointed to Amboina-Malay as one of the sources especially (2012: 370 371). He added that also the Indo-Aryan mother tongues of the slaves from India-Sri Lanka may have played a role in the emergence of the Afrikaans object marker vir. After all, these languages exhibit a so-called dative accusative, i.e. marking animate direct objects as indirect objects (2012: 373). As a result, the number of languages that may have contributed to the function expansion of Dutch voor is only increasing, which reinforces the probability of a creolization process.

\subsection{Brace negation}

Probably the most discussed phenomenon of Afrikaans is the double negation or as Roberge (2000) calls it brace negation. This negation does not occur in current Dutch and that is why the question of its origin has often been debated. Du Toit (1897: 30) starts the section 'Peculiarities of Cape Dutch' with it.

Just as in French Cape Dutch use (sic!) a double negation, probably this is to be traced back to the influence of the Huguenots.
Moet $n i$ gaan $n i$
'Do not go'
Gen een $n i$
'No one'

He already pointed to the assumed parallel in an earlier publication, the first Afrikaans grammar (1876): 'Just like in French, we have a double negation with our double use of nie' (Biberauer 2015: 42 fn. 14). Du Toit, however, was not the only one, who thought that the Afrikaans double negation originated in the similar French negation. Hesseling (1899: 117-118) also mentioned Mansvelt and Te Winkel. He then immediately showed that this hypothesis is implausible. The second nie in Afrikaans is sentence-final, whereas the second part of the French double negation, or in older Dutch double negations, immediately follows the verb:

$\begin{array}{lll}\text { French: } & \text { je } n \text { 'ai pas } & \text { 'I do not have' } \\ \text { Dutch: } & \text { ik en weet niet wat } & \text { 'I do not know what' }\end{array}$

Hesseling implicitly settled this with Taco de Beer (1882: 237) who claimed that the African brace negation came from an older (Middle) Dutch double negation. He was convinced that Afrikaans nie... nie was the same as the en... nie negation he still encountered in the work of the $17^{\text {th }}$ century Dutch poet Cats. The Dutch sentence above comes from De Beer who took the example from Jacob Cats.

Hesseling also pointed to the parallel that Du Toit saw here again with Hebrew. In Hebrew, a word may be repeated to emphasize. The same phenomenon also occurs in Afrikaans, where one can find: 
Dood is hy dood Dutch: Hij is zeker dood. 'He is most certainly dead'

Kom sal hy kom Dutch: Hij zal zeker komen 'He will certainly come'

Such a repetition has more often been put forward as the starting point for the double negation. Hesseling, however, could not find any parallel for the Afrikaans brace negation. Hesseling also referred to Schuchardt who found a similar case in a Creole Portuguese from Angola but his data are not very clear. The last option he suggested is an emphatic way of speaking, which can sometimes even lead to a threefold nie: Dis ni die kinderharp self ni wat ' $n$ mens kan sing $n i$ 'It is not the children's harp itself that one can sing'. Finally, Hesseling must conclude that he cannot answer the question whether the double negation has been taken over from another language or arises from a spontaneous Dutch/Afrikaans development. It is remarkable that the options Hesseling discussed keep returning in the remainder of the debate.

Before proposing his own hypothesis, Scholtz (1965: 22-24, 41-43, 90-91; 1980: 90-91), first emphatically rejected explanations based on Portuguese Creole (Valkhoff) and Hottentot (Nienaber) without, incidentally, providing any arguments for this. His own suggestion is in line with the possibility of repetition already mentioned by Hesseling. He presents brace examples such as al lank al 'for a long time' and uit die huis uit 'out of the house'. These could have served as basis for the brace repetition of the negation particle, thus for the double negation.

Apparently, his own suggestion did not convince Scholtz. Therefore, he also looked for similar constructions in older Dutch texts and Dutch dialects. Indeed, there have been a few dialects in the center part of the Netherlands in which niet....niet 'not....not' occasionally occurred but he could not find any attestations of this construction in the more relevant dialects of the provinces North- and SouthHolland. In the dialects of Flanders, however, the construction appeared to be more frequent. Question solved, for Scholtz. The construction is Dutch, be it that the use in Afrikaans is more emphatic which he explains from the great need to make yourself understood to foreigners.

Raidt (1976a) called 'repeated negation' a normal phenomenon that occurs in many languages. For instance, 'I didn't say nothing' is a normal construction in English vernacular. Similar constructions one may find in some German and Dutch dialects. In addition, she pointed to the Middle Dutch brace negation en ....niet, already mentioned by De Beer, which was still in use to deep in the $18^{\text {th }}$ century, according to her. ${ }^{97}$ There are, however, essential formal differences between the Afrikaans brace negation and the repeated negation found in other languages: the Afrikaans second nie may be optional and, what is even more important, the second

\footnotetext{
${ }^{97}$ There is no support for this claim in the Dutch linguistic literature. This is different for Afrikaans; Van Oordt (quoted in Van Rensburg 2015a: 91) confirms that the so called Veldwagtertekste 'Ranger texts' from the beginning of the $19^{\text {th }}$ century do not yet contain the Afrikaans brace negation but the old with en....niet.
} 
nie is sentence-final. All explanations of the origin so far failed, according to Raidt, till the Flemish dialectologist Pauwels (1958: 435-477) found exactly the Afrikaans brace negation in the dialect of the small Brabant town of Aarschot not far from Louvain. His and Raidt's conclusion is that emigrants from this region must have brought this construction with them. She solves the problem that the brace negation does not occur in texts before 1830 by pointing to the need of correctness. Literate people in South Africa wanted to write as correctly as possible, thus avoiding this construction. Finally, the present double nie-construction began to be so accepted from the beginning of the 19th century that it then appeared in written texts. Raidt (1983: 189-190) does not differ materially from her previous survey and explanation. She adds, however, one important fact: according to her, brace negation with a second nie does not occur in the Afrikaans language of the slaves and the Khoekhoe, as far as the data show that have been handed down.

Carstens and Raidt (2017: 463-465) looks in fact little more than a revised version of Raidt which is remarkable, because in the years after Raidt (1976a and 1983) much criticism has appeared on Pauwels' study and many alternative hypotheses have been put forward. Carstens and Raidt mention Ponelis (1993) and Den Besten (2012), ${ }^{98}$ and even Nienaber (1965) and Valkhoff (1966), but do not pay any attention to their arguments and proposals. They accept, however, Van Rensburg's (2015b: 334) argument against Pauwels' theory that consists in the strong fact that nowhere in the history of South Africa has there been any evidence of contact between speakers of the Aarschot dialect and Afrikaans. Even though Carstens and Raidt have to give up the strongest Eurocentric explanation, i.e. Pauwels' theory, they stick to another spontaneous-evolution hypothesis which says that the Afrikaans brace negation is a continuation and an expansion of the Middle Dutch double negation, as it still exists in some Dutch dialects. That this Middle Dutch negation is en ... nie instead of nie... nie, and the fact that the place in the sentence differs is apparently taken for granted. This could be expected, because one of the few extensions of the treatment of Carstens and Raidt compared to earlier work by Raidt is the addition of a motto from the work of the Dutch linguist Paardekooper, the only Dutch linguist from the second half of the $20^{\text {th }}$ century who advocated a Groot Diets thinking. ${ }^{99}$ Paardekooper who claimed elsewhere (2003) that Afrikaans is a continuation of the dialect of Amsterdam praises Pauwels' research 'as a result of which we know that this African construction corresponds almost completely to a FlemishBrabant system.' Incidentally, there are clear differences between Flemish and Brabant dialects themselves and the Amsterdam variety. The other extension of Car-

\footnotetext{
${ }^{98}$ Den Besten (2012) is Den Besten (1986) but is reprinted in Van der Wouden (2012: 221-256)

${ }^{99}$ This view, which was popular in some Flemish circles before the Second World War, included a quest for a renewed unity of the Netherlands and the Dutch/Flemish-speaking regions and a strong bond with the Afrikaner brothers in South Africa.
} 
stens and Raidt in comparison with Raidt (1976a and 1983) is a reference to Waher (1978), who discussed the scope of the two negation particles. ${ }^{100}$

Conradie $\left(2017^{2}\right)$ described the double negation in a chapter on changes in Afrikaans in the other handbook on Afrikaans, Carstens and Bosman (20172: 77-78). In fact, he takes much the same position as Raidt and Carstens and Raidt, although he does not accept the idea that Middle Dutch en ...nie is simply continued in the Afrikaans brace negation. He mentions the two best-known theories: the one proposed by Pauwels in combination and enhanced with comparable $17^{\text {th }}$ century Dutch double negations and the other one, proposed by Nienaber (1965) and refined by Den Besten $(1987=1986)$. Their explanation claims that Khoekhoe speakers who wanted to learn Dutch put a second negation particle at the end of the sentence since that is where they are used to put the negation marker in their own, also SOV, language. After all, Khoekhoe had sentence-final negation. Van Keymeulen (2019b: 108) reacts rather angrily to presenting both theories as equal. The Aarschot-explanation and the related Dutch dialect origin of the embracing Afrikaans negation is a language myth, according to him. Nienaber's and Den Besten's solution is much more plausible.

Before turning to this more plausible hypothesis a few words should be said about Valkhoff's (1966: 13-18) proposal that the Afrikaans brace negation originated in the African variety of Portuguese Creole and his criticism on other theories. Valkhoff disputed Pauwel's solution that Aarschots and other dialects from the Louvain region set in motion the Afrikaans brace negation. There were hardly any people from this region among the early immigrants ${ }^{101}$ and as far as there were, they did not arrive as a group nor at the same time. In addition, 'was their prestige so great that they were able to impose such an un-Dutch construction?', Valkhoff asks (1966: 16). In addition to his own explanation, Valkhoff also appreciates Nienaber's analysis (1955, reprinted as 1965) which shows that more than half of the surviving Afrikaans negative sentences of the Khoekhoe from the early 19th century contain a brace negation, whereas 'in the Afrikaans of the Whites [from the same period] there occurred 45 negative sentences, 7 with and 38 without final nie, or in percentages 16 per cent and 84 percent' (1966: 17).

Now the Nama language, for instance - the only one that is well recorded - does not have a double negation, but it has negative particles which precede or, more usually, fol-

${ }^{100}$ Waher's dissertation hardly played a role in the discussion about the brace negation in Afrikaans due to the theoretical framework she choose. She used the brace negation as an argument for a generative semantic approach. As is well-known (cf. Hamans and Seuren 2010) the generative semanticists lost the linguistic war against the so called 'interpretative semanticists'. Waher (1983) is a reformulation of Waher (1978) in terms of an interpretative semanticist framework.

${ }^{101}$ Altogether there were 13 Flemish people among the early settlers between 1657 and 1662 , which is some 8 percent of the total number. Whether they came from Flanders, from Limburg or from Brabant - Aarschot is in Brabant - cannot be determined. The number of Germans, for instance, was 40 in the same period. The number of Dutchmen was 104 (Valkhoff 1966: 15). 
low the verb. Most of them are placed after the verb (tama, tite, te); (...) When the Hottentots learnt to speak Cape Dutch they adopted the preverbal [Dutch] nie $(t)$, but at the same time they looked for a means to maintain their usual construction with a postverbal negation. To fill this hiatus they introduced another nie(t) behind the verb, and this usage was taken over by the White community itself, especially in the interior of the country where the Hottentots were farmhands, maid-servants, or playmates in the White family. (...)

So, both the creolized Dutch of the African slaves, who most likely knew a double negation in their own lingua franca, and that of the Hottentots, may have popularized a construction which sporadically occurred in the Netherlands (Valkhoff 1966: 17).

Even though Valkhoff turned out to be willing to make a small opening for older Dutch constructions, this did not mean that he also accepted, even for a small part, spontaneous evolution theories, as some of his private letters show. In one of his much-heard radio talks, the most extreme spontaneist Van der Merwe highly praised Pauwels' find and called it definitive proof of a Dutch ancestry of Afrikaans. Valkhoff reacted in a letter to Gawie Nienaber.

I can imagine that rather naive minds, such as the author [Pauwels] himself, and Afrikaans linguists who strive for diachronic language purity (by analogy with our "racial purity"!), have been greatly affected by this and now assume that the problem of origin of nie... nie in Afrikaans has been solved. (...) It seems to me very funny that e.g. the $8 \%$ Flemings who were free burghers there between 1657 and 1662 would have been liable for the double negation: 1 st it is not at all certain that they all used it, 2nd it seems strange that the other colonists simply took over this un-Dutch language turn from a few country fellows. (Schutte 2016) ${ }^{102}$.

Valkhoff also wrote a letter to Pauwels, in which he warned him that Afrikaners had to fight a language battle and that his argument could be used within it. Apparently Valkhoff did not realize that the Flemish-speaking Pauwels had also struggled through a largely French-speaking education in Louvain. He added that in Afrikaans linguistic politics is rarely far away.

Moreover, most of them tend to transfer the (unattainable and, for that matter, unattained) ideal of racial purity to language. (...) a tendency to underestimate or even deny foreign influences on language development. I must certainly reject the latter as an unscientific attitude. (Schutte 2016). ${ }^{103}$

102 'Ek kan my voorstel dat taamlik naïewe geeste, soos die skrywer [Pauwels] self en Afrikaanse taalgeleerdes wat na diachroniese taalsuiwerheid strewe (na analogie van ons "rassensuiwerheid"!), hierdeur baie getref is en nou aanneem dat die oorsprongsprobleem van nie...nie in Afrikaans opgelos is. (...) Dit lyk vir my baie snaaks dat bv. die 8\% Vlaminge wat daar tussen 1657 en 1662 vryburger was, vir die dubbele ontkenning anspraaklik sou gewees het: $1^{\mathrm{e}}$ is dit glad nie seker dat hulle almal gebruik het nie, $2^{\mathrm{e}}$ lyk dit vreemd dat die andere koloniste hierdie on-Hollandse taalwending sommer van ' $\mathrm{n}$ paar stamgenote oorgeneem het.'

103 'Bovendien hebben de meesten van hen de neiging het (onbereikbare en trouwens niet bereikte) ideaal der rassenzuiverheid op de taal over te brengen. (...) een neiging om vreemde invloeden op de 
Den Besten discussed the Afrikaans double negation several times. His most comprehensive study is den Besten (1986, reprinted in Van der Wouden 2012: 221-256). After having sketched the problem, Den Besten (Van der Wouden 2012: 240-241) first criticized Scholtz and Raidt who pointed to a few more or less coincidental examples of a double negation in some Dutch dialects. Unfortunately, no such examples have been attested for the settler's dialects. Subsequently, he discussed Pauwel's Aarschot hypothesis. The dialect of Aarschot even exhibits a negation consisting of three particles. The first at the place of the Dutch negation particle, the second in the middle field of the sentence and the third one sentence final. Unfortunately, the last one appears to be optional, which leaves the dialect with a double negation in which the second element is not sentence final, which is crucial for the Afrikaans brace negation. Den Besten (243) is also very skeptical about Valkhoff's Creole Portuguese explanation. The varieties of Creole Portuguese in which one comes across a double negation are from the Gulf of Guinea. Unfortunately, the Creole Portuguese slaves are from Asia. The Asian varieties of Creole Portuguese do not exhibit double or sentence final negation.

So, the only remaining option is the Hottentot/Khoekhoe hypothesis, proposed by Nienaber (1955/1965). Den Besten noticed that both Dutch and Nama, as an example of a Khoekhoe language, are SOV, which makes it not 'impossible that interference from Hottentot has created nie-2 in Afrikaans.' (Van der Wouden 2012: 244). The question that arises is what kind of language was the Hottentot-Dutch in which this nie-2 must have popped up. On the basis of archival data Den Besten is able to show that it is an SOV-pidgin that best can be described as a relexified Khoekhoe foreigner talk (2012: 248-249). Subsequently, he assumed that this pidgin was taken over by the slaves and therefore used more widely. Of course, the Portuguese Creole lingua franca influenced the Hottentot pidgin and vice versa. Thus, it is not unlikely that the slaves borrowed a sentence final nie-2 from the Khoekhoe pidgin. Via these groups nie-2 became part of the different varieties of Afrikaans (2012: 250). The problem Raidt (1983: 190) identified that there are no attested double negations in the speech of slaves and Khoekhoen before 1800 remains a difficult issue for Den Besten. Therefore, he analyzed more or less similar examples and even ingeniously re-analyzed a well-known early example, which then may become a first example of nie-2.This example would then have to be about 70 years older than all accepted attestations (Van der Wouden 2012: 254-256).

Although Van Keymeulen (2019b:108) called Den Besten's revision of Nienaber's hypothesis the most plausible theory about the origin of the brace negation in Afrikaans and even though Bell (2001) further developed this hypothesis and Van Rensburg (2015a): 91-92) put forward arguments in support, the proposal did not go

taalontwikkeling te onderschatten of zelfs te ontkennen. Dit laatste moet ik beslist als een onwetenschappelijke houding verwerpen.' 
unchallenged. Ponelis (1993: 33-35) accused him of having taken too little account of social factors and is not convinced of the existence of a 'partially stabilized KhoiDutch pidgin,' since the 'data are very scant and mingled with regular Dutch' (1993: 33). Groenewald (2002) has examined Den Besten's proposal for a pidgin that is shared by Khoekhoen and slaves in a broader context. Based on socio-historical data, he doubts the existence of such a stable pidgin, which does not mean that he denies the influence of the Khoekhoen and the slaves on the development of Afrikaans. Luijks (2012: 165) who, incidentally, is sympathetic to Den Besten's approach points to an essential problem for the Nienaber-Den Besten hypothesis: the lack of early attestations.

It has been argued that the origin of Afrikaans double negation has its roots in African substrates, specifically Nama and Koranna which realize a negative element clause finally (...). Notably, in the corpora of nineteenth-century Oorlam-Hollands [a specific kind of coloured Dutch $\mathrm{CH}$ ], despite the fact that this vernacular has to be characterized as having undergone major influence from Khoekhoe, this feature does not surface.

Her other data do not support the Nienaber/Den Besten proposal either. Deumert's (2004) research shows that around the turn of the $20^{\text {th }}$ century the brace negation was still very infrequent in the Cape-Dutch correspondence she investigated. It was a stigmatized, popular lower class phenomenon that was introduced into Standard Afrikaans by the language engineers for reasons of distinction from Dutch and only found its way into Standard Afrikaans after a long process. In effect, this means that the question of the origin of the brace negation in Afrikaans should be shifted to the question of the origin of the brace negation in one or in all the coloured non-standard varieties.

Roberge (2000), who also takes a creolization point of view towards Afrikaans, is not convinced by Den Besten. All the other theories appeared to be untenable, therefore he returned to an explanation that has already been advanced by Hesseling, the brace negation as a result of emphasis. Roberge argued that the brace negation in Afrikaans is an innovation that resulted from a process of convergent hybridization in which various segments of the colonial society took part. The starting point of his hypothesis is the sentence-final Dutch emphatic tag negation, nee or niet 'no'.

Dutch: Het kan niet waar zijn, nee!

Gloss: it can not true be no

'It cannot be true, no!

Dutch: Jij komt niet mee, nee?

Gloss: you come not with hey

'You aren't coming, hey/right? (Roberge 2000: 147)

This construction was relexified in the language(s) of the Khoekhoen and the slaves.Due to the intensive contact and language contact between them and lower 
class whites, this feature was also adopted by these whites and used in their language, albeit with variations (Roberge 2002: 98).

Biberauer (2007, 2008, 2009 and 2015), who investigated contemporary Afrikaans negation in depth, agreed with Roberge: nie-2 is a discourse oriented particle (2015: 129), an emphatic tag negator (2007: 112), a final polarity marker (2008: 111-112). Moreover, it is a late development in Afrikaans which explains why it has not been attested in earlier texts. Furthermore a discourse-related origin seems to bring this Afrikaans phenomenon in line with similar phenomena found in other languages (2015: 142). What is most special about the brace negation is that it does not follow Jespersen's Cycle (2009 and 2015), which also makes the quest for its origin a special enterprise. The idea that it should be related to a more common Dutch or Western European should be given up, she demonstrated.

The conclusion that seems to emerge is that the Afrikaans negation system is only superficially similar to more familiar Western European models. More specifically, it would seem to be the case that the mix of "exotic" contact considerations and ideologically motivated prescriptive intervention at the standardization stage has produced a system that children cannot straightforwardly acquire (Biberauer 2015: 164-165).

As is clear, the question of the exact status of the brace negation and its origin is far from answered. Biberauer therefore calls for further investigation. What is more or less clear is that there are no simple answers. A Dutch dialect background or an origin in earlier stages of Dutch appears virtually impossible, however much they may have been or still may be ideologically desirable at the time, but parallels with contact or indigenous languages also leave many questions unanswered. It is much too easy to use the brace negation as a proof for a white or black Afrikaans.

Biberauer (2015: 130) has the firm suspicion that, had his early death not prevented this from happening, Den Besten would also have gone in the direction that Roberge and Biberauer are following. An abstract which he produced shortly before he passed away announced new insights that led him to embrace Roberge's idea. Unfortunately we never will learn what these insights may have been.

\section{Conclusion}

This survey of the discussions about the origin of Afrikaans and the Cape Colony shows that the predominant feeling among the Afrikaners was that they were a special group. In the $17^{\text {th }}$ century they were the only 'civilized Westerners' at the tip of Africa, with all the colonial prejudices and feelings of superiority which go with it. After the British took over power at the Cape, the Afrikaners felt downgraded. Of course, from their point of view, not as far as to the level of the coloureds and the blacks, since they remained white. Nevertheless they were tempted to fight their way 
back up again. Their white language, Afrikaans, became instrumental in that fight. No wonder that Afrikaans scholars - and also some Dutch and German colleagues who felt solidarity with them - who studied this language, and especially its origin, wore ideological blinders. The moment they would find out that their dear language was not completely white, it would feel like betrayal of their struggle for emancipation. Therefore they not only could not see data which contradict their ideological stance, they even could not think of such an approach. It simply did not come to their mind. They never realized that they, due to this one-sided look, mainly saw data which were supportive to their own theories and that they had a blind eye for the weakness in their argumentation. Therefore, they reacted so furiously when some other scholars showed them that Afrikaans is as much creolized as it comes from WestGermanic sources. This does not imply that scholars who defended a Eurocentric or albocentric approach were crooks, betrayers, or cheaters. Not at all, they were serious and honest scholars, often fine philologists who suffered from a lack of being able to separate themselves from their environment. This, however, is not the prerogative of only this group of scholars. The creolists of the 1970s were as much influenced by the Zeitgeist, as the followers of the philological school, although modern times value an ideology founded in democratic equal rights much higher.

The dire problem arose under Apartheid, when all aspects of life and scholarship became highly politicized in South Africa. Apartheid, however, did not come like a bolt from the blue. It had been foreshadowed for some decades and that is why modern readership feels the thorns sticking out of linguistics texts since the 1920s. Unfortunately, the end of Apartheid did not bring an end to ideologization and politicization of life in South Africa and thus not of scholarship either. Therefore one may now want to call a language black that used to be seen as white but is actually coloured or brown.

\section{References}

Adhikari, M. 2005. Not white enough, not black enough. Racial identity in the South African coloured community. Athens: Ohio University Press.

ATM. 2016. Die Afrikaanse Taalmonument. Van Konsep tot Gestalten. Paarl: Taalmuseum.

Barnouw, A. 1934. Language and race problems in South Africa. Den Haag: Martinus Nijhoff.

Beer, T. de 1882. "Het Nederlands in Zuid-Afrika." Noord en Zuid 5. 229-239.

Bell, A.J. 2001. "Origins of negative concord in Afrikaans." In: Bell, A. and P. Washburn. (eds.). Cornell working papers in linguistics 18. Ithaca: Cornell University: 154-183.

Bergerson, J. 2011. Apperception and linguistic contact between German and Afrikaans. Unpublished $\mathrm{PhD}$ dissertation. Berkeley: University of California.

Besselaar, G. 1903. "Dr. Nicolaas Mantsvelt Wassenaar 30/7 1852 - Haarlem 6/2 1933." Jaarboek van de Maatschappij der Nederlandse Letterkunde 1934.93-102.

Besten, H. den. 1977. Afrikaans - mogelijke interferentieverschijnselen van andere talen op het Nederlands in zuidelijk Afrika. Unpublished paper for the meeting of the Creole Group 03.11.1977. Amsterdam: University of Amsterdam. 
Besten, H. den 1978. "Cases of possible syntactic interferences in the development of Afrikaans." In: Muysken, P. (ed.). Amsterdam Creole Studies II. Amsterdam: University of Amsterdam, Publikatie van het Instituut voor Algemene taalwetenschap 20: 5-56.

Besten, H. den 1981. "Marking WH-Movement in Afrikaans." In: Muysken, Pieter (ed.). Generative Studies in Creole Languages. Dordrecht: Foris: 141-179.

Besten, H. den 1985. "Die doppelte Negation im Afrikaans und ihre Herkunft." In: Boretzky, N. Enninger, W. and T. Stolz. (eds.). Akten des 1. Essener Kolloquiums über "Kreolensprachen und Sprachkontakte" vom 26.1.1985 an der Universität Essen. Bochum: Brockmeyer. 9-42.

Besten, H. den 1986. "Double negation and the genesis of Afrikaans." In: Muysken, P. and N. Smith. (eds.). Substrata versus Universals in Creole Genesis. Papers from the Amsterdam Workshop April 1985. Amsterdam/Philadelphia: 185-230. Also in Van der Wouden (2012). 221-256.

Besten, H. den 1987. "Het Afrikaans: Mag het ietsje meer Zuid-Afrika zijn?". Onze Taal 56. 24-25.

Besten, H. den 1989. "Review of Edith Raidt 1983. Einführung in Geschichte und Struktur des Afrikaans. Darmstadt: Wissenschaftliche Buchgesellschaft." Journal of Pidgin and Creole Languages 2. 67-92.

Besten, H. den 2000. "De diminutief in het Afrikaans: Kloeke, Scholtz en Ponelis opnieuw beschouwd." In: Berns, J.B. and J. Van Marle (eds.). Overzees Nederlands. Amsterdam: Meertens Instituut. 7-39.

Besten, H. den 2005. "Kloeke en het Afrikaans." Tijdschrift voor Nederlandse Taal- en Letterkunde 212. 211-224.

Besten, H. den and T. Biberauer. 2013. "Afrikaans structure dataset." In: Michaelis, S.M., Maurer, P., Haspelmath, M. and M. Huber. (eds.). Atlas of Pidgin and Creole structures Online. Leipzig: Max Planck Institute for Evolutionary Anthropology, https://apics-online.info/contributions/29 (retrieved 15.02.2021).

Besten, H. den, Hinskens, F. and J. Koch. (eds.). 2009. Afrikaans. Een drieluik. Amsterdam and Münster: Stichting Neerlandistiek VU and Nodus Publikationen.

Besten, H. den, Muysken, P. and N. Smith. 1994. "Theories focussing on the European input." In: Arends, J., Muysken, P. and N. Smith. (eds.). 1994. Pidgins and Creoles: an introduction. Amsterdam/Philadelphia: John Benjamins: 87-98.

Beukes, A.-M. 2004. The first ten years of democracy: language policy in South Africa. Paper read at the $X^{\text {th }}$ Linguapax Congress on Linguistic Diversity, Sustainability and Peace, 20-23 May 2004, Barcelona, https://citeseerx.ist.psu.edu/viewdoc/download?doi=10.1.1.120.4586\&rep=rep1\&type=pdf (retrieved 18.08. 2016).

Biberauer, T. 2007. "A closer look at negative concord in Afrikaans. Stellenbosch Papers in Linguistics Plus 35. 1-51.

Biberauer, T. 2008. "Doubling and omission: insights from Afrikaans negation." In: Barbiers, S., Koeneman, O., Lekakou, M. and M. van der Ham. (eds.). Microvariations in Syntactic Doubling. Bingley: Emerald. 103-140.

Biberauer, T. 2009. "Jespersen off course? The case of contemporary Afrikaans negation." In: Gelderen, E. Van. (ed.). 2009. Cyclic change. Amsterdam: John Benjamins: 91-130.

Biberauer, T. 2015. "Nie sommer nie. sociohistorical and formal comparative considerations in the rise and the maintenance of the modern Afrikaans negation system". Stellenbosch Papers in Linguistics Plus 47. 129-174.

Boshoff, S.P.E. 1921. Volk en Taal van Suid-Afrika. Kaapstad and Pretoria: Dusseau and De Bussy.

Bosman, D.B. 1916. Afrikaans en Maleis-Portugees. Groningen: Noordhoff. PhD dissertation Groningen University.

Bosman, D.B. 1922. “Afrikaanse taaltoestande tijdens Jan van Riebeeck.” De Nieuwe Taalgids 16. $113-125$.

Bosman, D.B. 1923. Oor die ontstaan van Afrikaans. Amsterdam: Swetz and Zeitlinger 
Bosman, D.B. $1928^{2}$. Oor die ontstaan van Afrikaans. Amsterdam: Swetz and Zeitlinger

Boshoff, S.P.E. and G.S. Nienaber. 1967. Afrikaanse Etimologieë. Pretoria: Die Suid-Afrikaanse Akademie vir Wetenskap en Kuns.

Bouman, A.C. 1923. "De Dubbele ontkenning in Afrikaans." De Nieuwe Taalgids 17. 17-23.

Bouman, A.C. 1924. "Het Afrikaans". De Nieuwe Taalgids 18. 122-131.

Bouman, A.C. 1928. "Ontlening en relikten in Afrikaans". De Nieuwe Taalgids 22. 37-41.

Boyce Hendriks, J. 1998. Immigration and linguistic change: a socio-historical linguistic study of the effect of German and southern Dutch immigration on the development of the northern Dutch vernacular in $16^{\text {th }} / 17^{\text {th }}$ century Holland. Unpublished $\mathrm{PhD}$ dissertation, University of Wisconsin, Madison.

Breytenbach, B. 2015. Parool/Parole. Versamelde Toesprake/Collected Speeches. Cape Town: Penguin.

Breytenbach, B. 2019. Mandela Lecture. Unpublished lecture University of Ghent 16.10.2019.

Brito, L. da Cruz. 2016. "The crime of miscegenation: racial mixing in slaveholding Brazil and the threat to racial purity in post-abolition United States." Revista Brasileira de História 36.72. 107-130. https://doi.org/10.1590/1806-93472016v36n72_007 (retrieved 19.12.2020).

Carstens, W.A.M. and N. Bosman. 2017². Kontemporêre Afrikaanse Taalkunde. Pretoria: Van Schaik.

Carstens, W.A.M. and M le Cordeur. (eds.). 2016. Ons kom van vêr. Bijdraes oor bruin Afrikaanssprekendes se rol in die ontwikkeling van Afrikaans. Tygervallei: Naledi.

Carstens, W.A.M. and E.H. Raidt. 2017. Die storie van Afrikaans uit Europa en van Afrika. Biografie van ' $n$ taal. Vol. 1 Pretoria: Protea.

Carstens, W.A.M. and E.H. Raidt. 2019. Die storie van Afrikaans uit Europa en van Afrika. Biografie van ' $n$ taal. Vol. 2 Pretoria: Protea.

Colenbrander, H.T. 1902. De afkomst der Boeren. Dordrecht: Algemeen Nederlandsch Verbond.

Conradie, J. 2017². "Taalverandering in Afrikaans". In: Carstens, W.A.M. and N. Bosman. (eds.). 63-91.

Conradie, J. and G. Groenewald. 20172. "Die ontstaan en vestiging van Afrikaans". Carstens, W.A.M. and N. Bosman. (eds.). 29-62.

Cordeur, M.L.A. le. 2010a. "Bal die vuis vir Kaaps". Rapport 10.03.2010.

Cordeur, M.L.A. le. 2010b. "Ek doen wat ek doen omdat ek wil". Rapport 04.04.2010.

Cordeur, M.L.A. le. 2015. "Bruinmense se stryd teen apartheid gedokumenteer". Tydskrif vir Geesteswetenskappe 55. 507-510.

Crijnen, T. 1999. "De wrok tegen het perfide Albion". Trouw 09.10.1999.

Davids, A. 2011. The Afrikaans of the Cape Muslims from 1815 to 1915. Ed. by Hein Willemse and Suleman E. Dangor. Pretoria: Protea.

Deumert, A. 2002. "Standardization and social networks. The emergence and diffusion of standard Afrikaans". In: McLelland, N. and A.R. Linn. (eds.). Standardization. Studies from the Germanic Languages. Amsterdam/Philadelphia: John Benjamins. 1-25.

Deunmert, A. 2004. Language standardization and language change. The dynamics of Cape Dutch. Amsterdam/Philadelphia: John Benjamins.

Diemel, R. Van. 2016. "Waarom Isak Mortel -'n Proefiet van Jesus - sy rug op die NG Kerk gekeer het." In: Carstens W.A.M. and M le Cordeur (eds.). 2016. 93-110.

Elphick, R. and H. Giliomee. (eds.). 1989. The Shaping of South African Society 1652-1840. Cape Town: Maskew Miller Longman.

February, V. 1991/2009². The Afrikaners of South Africa. Abingdon: Routledge.

Franken, J.L.M. 1927. "Die taal van die Slawekinders en Fornikasie met Slavinne". Tydskrif vir Wetenskap en Kuns 6. 21-40.

Giliomee, H. 2004. The rise and possible demise of Afrikaans as public language. Cape Town: University of Cape Town. Praesa Occasional Papers 14. 
Giliomee, H. 2009². The Afrikaners. Biography of a People. Charlottesville: University of Virginia Press.

Giliomee, H. 2012. "Afrikanernasionalisme, 1875-1899", "Afrikanernasionalisme, 1902-1924", “" $\mathrm{n}$ "Gesuiwerde" nasionalisme 1924-1948", "Aanpas of Sterf", and "Opstand, oorlog en oorgang". In: Pretorius (ed.): 219-232, 275-292, 293-309, 389-404 and 405-427.

Glind, J.J.(H.) van de. 2016. Ons gebruik ons in die plek van wij. Unpublished BA thesis University of Utrecht, https://dspace.library.uu.nl/bitstream/handle (retrieved 08.12.2020).

Gobineau, A. de. 1853. Essai sur l'inégalité des races humaines. Paris: Librairie de Firmin Didot Frères.

Gosselink, M., Holtrop, M. and R. Ross. (eds.). 2017. Goede Hoop. Zuid-Afrika en Nederland. Amsterdam and Nijmegen: Rijks Museum and Van Tilt.

Gosselink, M. 2017. "De Khoikhoi en de Nederlanders rond 1600". In: Gosselink, M., Holtrop, M. and R. Ross. (eds.). 33-43.

Grebe, H. 2009. "De taal is gans het volk - taalstandaardisatie en constructie van identiteit". Neerlandica extra Muros. 21-34.

Grebe, H. 2012. Op die keper beskou. Oor die ontstaan van Afrikaans. Pretoria: Van Schaik.

Grobler, J. 2012. "Swart verset teen apartheid, 1950's-1980's”. In: Pretorius (ed.) (2012): 369-388.

Groenewald, G. 2002. Slawe, Khoekhoen en Nederlandse Pidgins aan die Kaap, ca 1590-1720: ' $n$ Kritiese Ondersoek na die Sociohistoriese Grondslae van die Konvergensieteorie oor die Ontstaan van Afrikaans. Unpublished MA thesis, University of Cape Town, https://open.uct.ac. za/handle/ 11427/7911 (retrieved 11.102019).

Groenewald, G. 2019. "Slaves, Khoikhoi and the Genesis of Afrikaans: the development of a Historiography, ca. 1890s-1900s." South African Journal of Cultural History/ Suid-Afrikaanse Tydskrif vir Kultuurgeskiedenis 33. 2. 1-24.

Hahn, T. 1882. Address at the South African Public Library on Saturday, $29^{\text {th }}$ April 1882. Cape Town: Hermann Michaelis.

Hamans, C. and P. Seuren. 2010. “Chomsky in search of a pedigree.” In: Kibbee, D.A. (ed.). Chomskyan (R)evolutions. Amsterdam/Philadelphia: John Benjamins. 377-394.

Heever, R. van den. 1987. Tree na vrijheid. ' $n$ Studie in Alernatiewe Afrikaans. Bellville: Cape Professional Teachers Union.

Hesseling, D.C. 1899. Het Afrikaansch. Bijdrage tot de geschiedenis der Nederlandsche Taal in ZuidAfrika. Leiden: Maatschappij der Nederlandsche Letterkunde.

Hesseling, D.C. 1905. Het Negerhollands der Deense Antillen. Leiden: Sijthoff.

Hesseling, D.C. 1919. "Nog eens die als lidwoord". De Nieuwe Taalgids 13. 95-96.

Hesseling, D.C. $1923^{2}$. Het Afrikaansch. Bijdrage tot de geschiedenis der Nederlandsche Taal in ZuidAfrika. Revised and enlarged edition. Leiden: Brill.

Hinskens, F. 2009. "Zuid-Afrika en het Afrikaans. Inleidende notities over geschiedenis, taal- en letterkunde". In: Besten, H.den, Hinskens F. and J. Koch (eds.). 9-33.

Holm, J. 2000. "Semi-creolization: Problems in the development of a theory". In: Neumann-Holzschuh, I. and E.W. Schneider. (eds.). Degrees of Restructuring in Creole Languages. Amsterdam/Philadelphia: John Benjamins: 19-40.

Holm, J. 2004. Languages in contact: the partial restructuring of vernaculars. Cambridge: Cambridge University Press.

Holm, J. 2012. "Partial restructuring. Dutch on the Cape and Portuguese in Brazil". In: Wouden, T. van der (ed.). Roots of Afrikaans. Selected writings of Hans den Besten. Amsterdam/Philadelphia: John Benjamins: 399-417.

Hulshof, A. 1941. "H.A. Van Reede tot Drakestein, journaal van zijn verblijf aan de Kaap". Bijdragen en Mededeelingen van het Historisch Genootschap 62. 1-245.

Huigen, S. 2008. “Taalmonumenten". De Gids. 881-892. 
Hutton, C. 1999. Linguistics and the third Reich. Mother-tongue fascism, race and the science of language. London and New York: Routledge.

Ideh, A.E., and J.O. Onu. 2017. "Multilingualism and the New Language Policy in South Africa: Innovation and Challenges". Covenant Journal of Language Studies 5. 65-83.

Ifekwunigwe, J. (ed.). 2004. Mixed race studies. A reader. London: Routledge.

Jaarsveld, F.A. van. 1961. The awakening of Afrikaner nationalism 1868-1881. Kaapstad: Human and Rousseau.

Jansen, E. 2003a. "Het voortbestaan van de zeventiende eeuwse Khoi-vrouw Krotoa in de Zuid-Afrikaanse historiografie en letterkunde". Indische Letteren 18. 69-81.

Jansen, E. 2003b. 'Ewa, was ê hulle?'. 'Konstruksies van Krotoa in Suid-Afrikaanse tekste. Amsterdam: Vossiuspers. Inaugural lecture University of Amsterdam.

Jordaan, A.M. 2004. Mites rondom Afrikaans. Unpublished PhD dissertation, Universiteit van Pretoria.

Kannemeyer, J.C. 1974. Die Afrikaanse Bewegings. Pretoria: Academica.

Kannemeyer, J.C. 1996². Langenhoven ' $n$ Lewe. Kaapstad: Tafelberg.

Keymeulen, J. van. 2010. "Standaardisatie en destandaardisatie bij Vlamingen en Afrikaners. Parallellen en verschillen.” In: Wal, M. van der and E. Franken. (eds.). Standaardtalen in beweging. Amsterdam and Münster: Stichting Neerlandistiek VU and Nodus Publikationen: 135-152.

Keymeulen, Jacques van (2018) "Het afschalen van het Afrikaans: een politieke stommiteit." Literator 39,2 https://iterator.org.za/index.php/literator/article/view/1510/2735 (retrieved 09.01.2020).

Keymeulen, J. van. 2019a. "Een boek van de bruinmense voor de witmense". Internationale Neerlandistiek 57. 83-87.

Keymeulen, J. van. 2019b. “Een boek voor studenten.” Internationale Neerlandistiek 57. 106-109.

Kloeke, G.G. 1950. Herkomst en Groei van het Afrikaans. Leiden: Universitaire Pers Leiden.

Kloss, H. 1977. The unfolding of Afrikaans in its Germanic, African and world context. Pietersburg: University of the North.

Kotzé, I. and J. Kirsten. 2016. "The heritage of a language: discourses of purism in Afrikaans historical linguistics". Language Matters 47. 349-371.

Kotzé, E.F. 1983. Variasiepatrone in Maleier-Afrikaans. Unpublished PhD dissertation, University of Witswatersrand, Johannesburg, available at http://wiredspace.wits.ac.za/handle/10539/17787 (retrieved 17.03.2016).

Kotzé, E.F. 1989. "How creoloid can you be. Aspects of Malay Afrikaans." In: Pütz, Martin, and Dirven, René (eds.). Wheels within wheels: papers of the duisburg symposium on Pidgin and Creole languages. Frankfurt a.M.: Peter Lang: 251-364.

Kotzé, E.F. 2005. Effects of attitudinal changes towards Creolization in Afrikaans. http://www.larrymcel hiney.com/Creole.htm (retrieved 14.02.2021).

Kotzé, E.F. 2018. "The classification of Afrikaans". Litnet 29.05.2018

www.litnet.co/za/the-classification-of-afrikaans/ (retrieved 07.06.2018). Afrikaans version: "Is Afrikaans uitheems?" Litnet 18.04.2018.

Kriel, M. 2013. Loose continuity: the post-apartheid Afrikaans language movement in historical perspective. Unpublished $\mathrm{PhD}$ dissertation, The London School of Economics and Political Science (LSE). http://etheses.lse.ac.uk/863/1/_lse.ac.uk_storage_LIBRARY_Secondary_libfile_shared_repo sitory_Etheses_Content_Theses\%20submitted $\% 20$ by $\% 20$ students $\% 20 \% 26 \% 20$ alumni_Live $\% 20$ the ses_Kriel_continuity_post-apartheid_Afrikaans_language_historical_\%28public\%29.pdf (retrieved 08.07.2018).

Kriel, M. 2018. "Chronicle of a Creole: the ironic history of Afrikaans". In: Knörr, J. and W. Trajano Filho. (eds.). Creolization and Pidginization in contexts of postcolonial diversity. Leiden: Brill. $132-157$.

Kruisinga, E. 1906. "De oorsprong van het Afrikaans". Taal en Letteren 16. 417-439. 
Langenhoven, C.J. Versamelde werke. Vol. 12 Pretoria: Nasionale Pers.

Langner, D. 2014. Kaart en Koördinaat. 'Gids vir jong Afrikanerleiers. Pretoria: FAK.

Langner, D. and D. du Plessis. 2015. Taalpioniers. Pretoria: FAK.

Luijks, C. 2009. "Connecting the Cape Dutch vernacular with Orange River Afrikaans: Images from the nineteenth century.” In: Den Besten, Hinskens and J. Koch. (eds.). 149-175.

Markey, T.L. 1982. “Afrikaans: Creole or non-Creole?”. Zeitschrift für Dialektologie und Linguistik 49. 169-207.

Meyer-Benfey, H. 1901. Die Sprache der Buren. Einleitung, Sprachlehre und Sprachproben. Göttingen: Wunder.

Merwe, H.J.J.M. van der. 1951. An introduction to Afrikaans (leerboek vir nie-Afrikaanstaliges met platekursus oor die uitspraak van Afrikaans). Kaapstad: Balkema.

Merwe, Henderik J.J.M. van der. 1961. "Review of M. de Villiers: Nederlands en Afrikaans (Nas. Boekhandel, Kaapstad, 1960, pp. 75)”. De Nieuwe Taalgids 54. 235.

Merwe, H.J.J.M. van der. (ed.). 1963. Inleiding tot die Taalkunde. Pretoria: Van Schaik.

Merwe, H.J.J.M. van der. (ed.). Studierigtings in die Taalkunde. Pretoria: Van Schaik.

Merwe, H.J.J.M. van der, et al. (eds.). 1968. Afrikaans - sy aard en ontwikkeling. Pretoria: Van Schaik.

Merwe, H.J.J.M. van der. 1974. "Die oerwortels van Afrikaans." In: Kok, B. Federasie van Afrikaanse Kultuurvereniginge. (eds.). 1974. Afrikaans: ons pêrel van groot waarde. Johannesburg: FAK. 21-33.

Munger, E.S. 1974. The Afrikaner as seen abroad. Pasadena, California: California Institute of Technology. Munger Africana Library Notes No. 26. Unpublished paper, available at https://authors.library. caltech.edu/25676/ (retrieved 17.08.2018).

Muysken, P. and N. Smith. 1994. "The study of pidgin and Creole languages". In: Arends, J., Muysken, P. and N. Smith. (eds.). 1994. Pidgins and Creoles: an introduction. Amsterdam/Philadelphia: John Benjamins. 3-14.

Nel, R. 2016. "Genote, Gelowig en Geskei: ' $n$ Postkoloniale beoordeling van die ontstaan van afsonderlike sendingskerke aan die Kaap, 1652-1881." In: Carstens and Cordeur (eds.). 57-71.

Nienaber, G.G.S. 1949. Oor Afrikaans I. Johannesburg: Afrikaanse Pers Boekhandel.

Nienaber, G.G.S. 1953. Oor Afrikaans II. Johannesburg: Afrikaanse Pers Boekhandel.

Nienaber, G.G.S. 1959. “"n Taaleigenaardigheid uit Hottentots”. Tydskrif vir Volkskunde en Volkstaal 15. $1-8$.

Nienaber, G.G.S. 1963. Hottentots. Pretoria: Van Schaik.

Nienaber, G.G.S. 1965. "Iets naders oor die ontkenning in Afrikaans". In: Nienaber, P.J. (ed.). Taalkundige Opstelle. Kaapstad: Balkema. Reprint of Nienaber (1955) "Iets naders oor die ontkenning in Afrikaans". Hertzog-Annale 2. 29-45.

Nienaber, G.G.S. 1989a. Khoekhoense Stamname: 'n Voorlopige Verkenning. Pretoria: Academica.

Nienaber, G.G.S. 1989b. “"Khoekhoen”wen die naamstryd teen "Hottentot”." Nomina Africana 3. 89-120.

Nienaber, G.G.S. 1994a. "Die ontstaan van Khoekhoe-Afrikaans." In: Olivier, G. and A. Coetzee. (eds.). Nuwe perspektiewe op die geskiedenis van Afrikaans. Pretoria: Southern Boekuitgewers. 139-152.

Nienaber, G.G.S. 1994b. "Khoekhoe vervang Hottentot". Suid-Afrikaanse Tydskrif vir Taalkunde. Supplement 21. 180-209.

Niekerk, L. van 1916. De eerste Afrikaansche taalbeweging en zijne letterkundige voortbrengselen. Amsterdam: Swets and Zeitlinger. $\mathrm{PhD}$ dissertation University of Amsterdam.

Noordegraaf, J. 2003. "Het Afrikaanse alternatief: A.N.E. Changuion (1803-1881) en het WNT". Trefwoord 2003. May. 1-11.

Noordegraaf, J. 2004. "Van 'Kaapsch Hollandsch' naar 'Afrikaans'. Visies op verandering”. In: Janssen, T., Daalder, S. and Noordegraaf. (eds). Taal in verandering. Artikelen aangeboden aan Arjan van Leuvensteijn bij zijn afscheid van de opleiding Nederlandse Taal en Cultuur aan de VU. Amsterdam and Münster: Stichting Neerlandistiek VU and Nodus Publikationen. 169-184. 
Noordegraaf, J. 2014. "Verre Verwanten. D.C. Hesseling (1859-1941) over taal en taalverandering." In: Velde, F. van de, et al. (eds.). Patroon en argument. Een dubbelfeestbundel bij het emeritaat van William van Belle en Joop van der Horst. Leuven: Universitaire Pers. 523-535.

Odendaal, B.G.G. 2012. Die herstandaardisering van Afrikaans: 'n Praktiese benadering met die AWS as gevallestudie. Unpublished $\mathrm{PhD}$ dissertation University of Stellenbosch, available at https://scholar.sun.ac.za/handle/10019.1/71820 (retrieved 04.12.2020).

Odendaal, G. 2014. "Moet Afrikaans geherstandaardiseer word? Should Afrikaans be restandardised?" Tydskirf vor Geesteswetenskappe 54. 656-674.

Oosthuizen, J. 2021. "Griefskrif met sewe eise vir Afrikaans aan US oorhandig". Litnet 09.04.2021, https://www.litnet.co.za/griefskrif-met-sewe-eise-vir-afrikaans-aan-us-oorhandig/ (rertrieved 10.04.2021).

Paardekooper, P.C. 1969. “Een Fransvlaams-Zeeuwse parallel - ons 'wij'.” Taal en Tongval 21. 211-215.

Paardekooper, P. 2003. “Afrikaans is Amsterdams”. Taalschrift 24.09 .03 https://taalschrift.org/discussie/ 000191.html (retrieved 25.092003)

Pauwels, Jan L. (1958): Het dialect van Aarschot en omstreken. Brussel: Belgisch Interuniversitair Centrum voor Neerlandistiek.

Pearl, B. 2021. "US-Taaldebat 2021: Ek is Afrikaaps". Litnet 26.03.2021, https://www.litnet.co.za/ustaaldebat-2021-ek-is-afrikaaps/ (retrieved 26.03.2021)

Pheiffer, R.H. 1979. 150 Jaar Gelede, Nederlands, Afrikaans, Engels aan die Kaap. Kaapstad: Universiteit van Kaapstad.

Plaatjies-Van Huffel, M.-A. 2016. "Afrikaans: voertaal, kerktaal, strydtaal in die Nederduitse Gereformeerde Sendingskerk en die Verenmigde Gereformeerde Kerk in Suider-Afrika." In: Carstens and Cordeur. (eds.). 72-92

Plessis, H. du. 1987. Variasietaalkunde. Pretoria: Serva.

Plessis, H. Du. 1995. “Taalverskeidenheid in Afrikaans as spieëel van sy kontaktgeskiedenis.” In: Ester, H. and A. van Leuvensteijn. (eds.). Afrikaans in een veranderende context. Taalkundige en letterkundige aspecten. Amsterdam: Suid-Afrikaans Instituut. 144-160.

Ponelis, F.A. 1991. "Nederlands in de geschiedenis van het Afrikaans". Forum der Letteren. 190-199.

Ponelis, F.A. 1993. The development of Afrikaans. Frankfurt a.M: Peter Lang.

Ponelis, F.A. 1997. “Afrikaans”. In: Horst, J.M. et al. (eds.). Geschiedenis van de Nederlandse taal. Amsterdam: Amsterdam University Press. 597-645.

Posthumus, N. 2020. "In Kaapstad vereerd en verguisd, maar is het hem wel?" Trouw 16.07.2020.

Postma, W. 1912. "Die Afrikaanse taal. Die ontstaan daarvan". Brandwag 15.02.1912 and 01.03.1912. 593-596 and 623-627.

Pretorius, F. (ed.). 2012. Geskiedenis van Suid-Afrika. Van voortye tot vandag. Kaapstad: Tafelberg.

Rademeyer, J.H. 1938. Kleurlingafrikaans: Die taal van die Griekwa en Rehoboth-Basters. Amsterdam: Swets and Zeitlinger.

Raidt, E.H. 1975. "Nuwe aktualiteit van 'n ou polemiek." In: Afrikaans: dit is ons erns. Pretoria: Akademie vir Wetenskap en Kuns. 39-54.

Raidt, E.H. 1976a. Afrikaans en sy Europese Verlede. Van Tacitus tot Van Wyk Louw. Kaapstad: Nasou.

Raidt, E.H. 1976b. "Die herkoms van objekskonstruksies met VIR." In: Suid-Afrikaanse Akademie vir Wetenskap en Kuns (ed.): 1875-1975, Studies oor die Afrikaanse taal. Johannesburg: Perskor. 73-101.

Raidt, E.H. 1977. “Afrikaans and "Malayo-Portugiese": Light and Shadow." African Studies 36, 71-78.

Raidt, E.H. 1983. Einführung in Geschichte und Struktur des Afrikaans. Darmstadt: Wissenschaftliche Buchgesellschaft.

Rawlings, A. 2020. Is Afrikaans in danger of dying out? BBC Future 15.05.2020. www.bbc.com/future/ article/20200514-is-afrikaans-in-danger-of-dying-out (retrieved 19.11.2020)

Reinecke, J. 1937. Marginal languages: a sociological survey of the Creole languages and trade jargons. Unpublished PhD dissertation, Yale University, New Haven, Connecticut. 
Reinecke, J.E. 1975. A Bibliography of Pidgin and Creole languages. Honolulu: University of Hawai'i Press.

Renders, L. 2005. "Het Afrikaans, een taal in het strijdperk." Neerlandia, Nederlands van Nu 109. 11-14.

Rensburg, M.C.J. van. 1989. "Soorte Afrikaans". In: Botha, T. (ed.). Inleiding tot die Afrikaanse taalkunde. Pretoria: Academica. 436-467.

Rensburg, M.C.J. van. 1990. Taalvariëteite en die wording van Afrikaans in Afrika. Bloemfontein: Patmos.

Rensburg, M.C.J. van. 1992. "Die demokratisering van Afrikaans.” In: Webb, V.N. (ed.). Afrikaans ná Apartheid. Pretoria: Van Schaik. 181-197.

Rensburg, M.C.J. van. 1996. "Is Koi-invloed op Afrikaans werklik Koi-invloed?“ In: Besten, H. den, et al. (eds.). Afrikaans en variëteiten van het Nederlands. Amsterdam and Gent: Taal en Tongval. Themanummer 9. 128-145.

Rensburg, M.C.J. van. 1999. “Afrikaans na apartheid.” International Journal of the Sociology of Language 136. 77-95.

Rensburg, M.C.J. van. 2012a. So kry ons Afrikaans. Pretoria: LAPA.

Rensburg, M.C.J. 2012b. “Afrikaans lekker ná skep uit baie tale.” Beeld 4 September. www.beeld.com/ MyBeeld/Briewe/Afrikaans-lekker-na-skep-uit-baie-tale-20120904 (retrieved 13.10.2015).

Rensburg, M.C.J. van. 2013. “"n Perspektief op 'n periode van kontak tussen Khoi en Afrikaans”. Literator 34.2. 1-11

Rensburg, M.C.J. van. 2015a. "Khoi en Oostgrensafrikaans". Stellenbosch Papers in Linguistics Plus 47. 75-97.

Rensburg, M.C.J. van. 2015b. "Oor die eerste 50 jaar se maak aan Standaardafrikaans. Creating a standardised version of Afrikaans - the first 50 years". Tydskrif vir Geesteswetenskappe 55. 319-342.

Rensburg, M.C.J. van. 2016. "Die vroegste Khoi-Afrikaans.” Tydskrif vir Geesteswetenskappe 56. 454- 476.

Rensburg, M.C.J. van. (ed.). 1997. Afrikaans in Afrika. Pretoria: Van Schaik.

Rensburg, M.C.J. van, Davids, A., Ferreira, J., Links, T. and K.P. Prinsloo. (eds.). 1997. Afrikaans in Afrika. Pretoria: Van Schaik.

Rijn, C.J. van. 1914. Het nauwe verband tussen het Afrikaans en het Hollands, tot in kleine biezonderheden uitgewerkt. Voor onderwijzers, predikanten en alle belangstellenden. Kaapstad: T. Maskew Miller.

Roberge, P.T. 1986. "What's happening in Afrikaans historical linguistics? Comments on the new introduction by Edit H. Raidt: Einführung in Geschichte und Struktur des Afrikaans (1983)". Zeitschrift für Dialektologie und Linguistik 53. 194-202.

Roberge, P.T. 1990. "The ideological profile of Afrikaans historical linguistics." In: Joseph, J.E. and T.J. Taylor. (eds.). Ideologies of language. London and New York: Routledge. 131-149.

Roberge, P.T. 1992. "Afrikaans and the ontogenetic myth." Language and Communication 12. 31-52.

Roberge. P.T. 1994. The formation of Afrikaans. Stellenbosch papers in linguistics plus 23.

Roberge, P.T. 2000. "Etymological opacity, hybridization and the Afrikaans brace negation." American Journal of Germanic Linguistics 12. 101-176.

Roberge, P.T. 2002. "Afrikaans: Considering origins." In: Mesthrie, R. (ed.). Language in South Africa. Cambridge: Cambridge University Press. 79-103.

Roberge, P.T. 2003. “Afrikaans”. In: Deumert, A. and W. Vandenbussche (eds.). Germanic standardizations. Past to Present. Amsterdam/Philadelphia: John Benjamins. 15-40.

Roberge, P.T. 2006. "The development of creolistics and the study of pidgin languages. An overview." In: Auroux, S. et al. (eds.). History of the language sciences: An international handbook on evolution of the study of language from the beginnings to the present: Berlin: De Gruyter 3. 2398-2413.

Ross, R. 2017. "De wereld die de Nederlanders binnenvielen: prekoloniaal Zuid-Afrika.” In: Gosselink, M., Holtrop, M. and R. Ross. (eds.). Goede Hoop. Zuid-Afrika en Nederland. Amsterdam and Nijmegen: Rijks Museum and Van Tilt. 21-31. 
Roux, J.J. le. 1921. Handleiding in het Afrikaans voor Nederlanders. Amsterdam: S.L. van Looy.

Scher, D.M. 2012. "Die vestiging van die apartheidstaat, 1948-1966". In: Pretorius (ed.). 325-343.

Scholtz, J. du Plessis. 1963. Taalhistoriese Opstelle. Voorstudies tot 'n Geskiedenis van Afrikaans. Pretoria: Van Schaik.

Scholtz, J. du Plessis. 1965. Afrikaans uit die vroeë tyd: studies oor die Afrikaanse taal en literêre volkskultuur van voor 1875 . Kaapstad: Nasou.

Scholtz, J. du Plessis. 1980. Wording en Ontwikkeling van Afrikaans. Kaapstad: Tafelberg.

Schonken, F.T. 1914. De oorsprong der Kaapsch-Hollandsche volksoverleveringen. Ed. by D. Fuldauer, transl. by Selly de Jong. Amsterdam: Swets and Zeitlinger.

Schuchardt, H. 1885. "Review of N. Mansvelt Proeve van een Kaapsch-Hollands Idioticon." Literaturblatt für germanische und romanische Philologie 6. 464-470.

Schuchardt, H. 1880. "Kreolische Studien IX. Ueber das Malaioportugiesische von Batavia und Tugu". Sitzungsberichte der philosophisch-historischen Classe der Kaiserlichen Akademie der Wissenschaften. Wien 122. 1-256.

Shell, R. 2012. "Mense in knegschap" In: Pretorius (ed.). 63-71.

Schutte, G. 2016. "Archiefvormers en erflaters (3): Prof. dr. M.F. Valkhoff, taalkundige". Maandblad Zuid-Afrika. August. 164.

Slomanson, P. 1993. "Hesseling and Van Ginniken on Language Contact, Variation, and Creolization." In: Byrne, F. and J. Holm. (eds.). Atlantic meets Pacific: a global view of pidginization and creolization. Amsterdam/Philadelphia: John Benjamins. 419-428.

Sluijs, R. van. 2013. "Survey Chapter, Afrikaans." In: Michaelis, S.M., Maurer, P., Haspelmath, M. and M. Huber. (eds.). Atlas of Pidgin and Creole structures Online. Leipzig: Max Planck Institute for Evolutionary Anthropology. https://apics-online.info/surveys/29 (retrieved 15.02.2021).

Smith, J.J. 1927. "The evolution and recognition of the Afrikaans language/Die ontwikkeling en erkenning van die Afrikaanse taal". Official year book of the Union 8. 14-23.

Smith, J.J. 1952. Theories about the origins of Afrikaans. Johannesburg: Witwatersrand University Press.

Stell, G. 2010a. "Grammaticale variatie in het informele gesproken Afrikaans. Standaardisatie 'from above' en standaardisatie 'from below'." In: Wal, M. van der and E. Franken. (eds.). Standaardtalen in beweging. Amsterdam and Münster: Stichting Neerlandistiek VU and Nodus Publikationen. $109-134$.

Stell, G. 2010b. "Afrikaanse spreektaalnormen en prescriptieve Afrikaanse normen: Is er genoeg ruimte voor grammaticale diversiteit in het Standaardafrikaans?" Tydskrif vir Geesteswetenskappe 50. 418-444.

Steyn, J.C. 2014. "Ons gaan 'n taal maak". Afrikaans sedert die Patriot-jare. Pretoria: Kraal.

Templin, J.A. 1999. "The ideology of a chosen people: Afrikaner nationalism and the Ossewa Trek, 1938". Nations and Nationalism 5. 397-417.

Titus, D. 2016. “Afrikaanse boek van bruin kant - Taal en identiteit op die Afrikaanse werf." In: Carstens and Cordeur (eds.). 182-203.

Toit, P.J. du. 1905. Afrikaansche Studies. Gent: Siffers.

Toit, S.J. du. 1897. Fergelijkende Taalkunde fan Afrikaans en Engels. Paarl: Du Toit.

T'Sjoen, Y. 2021. "Op de barricaden voor Afrikaans". Neerlandistiek 08.04.2021, https://neerlandi stiek.nl/2021/04/op-de-barricaden-voor-afrikaans/ (retrieved 09.04.2021).

Valkhoff, M.F. 1941. De Expansie van het Nederlands. Den Haag: Leopold.

Valkhoff, M.F. 1943². De Expansie van het Nederlands. Revised and enlarged edition. Brussel: Manteau.

Valkhoff, M.F. 1966. Studies in Portuguese and Creole. With Special reference to South Africa. Johannesburg: Witwatersrand University Press. 
Valkhoff, M.F. 1971. "Descriptive bibliography of the linguistics of Afrikaans: a survey of major works and authors." In: Sebeok, T. (ed.). Current trends in linguistics. Vol. 7. Linguistics in Sub-Saharan Africa. The Hague and Paris: Mouton. 455-500.

Valkhoff, M.F. 1972. New lights on Afrikaans and 'Malayo-Portuguese'. Louvain: Éditions Peeters.

Viljoen, W.J. 1896. Beiträge zur Geschichte der Cap-Holländischen Sprache. Strassburg: Trübner.

Villiers, J. de. 2012. "Die Nederlandse era aan die Kaap, 1652-1806" and "Die Kaapse samelewing onder Britse bestuur, 1806-1834." In: Pretorius (ed.). 39-62 and 73-96.

Vlasblom, D. 2017. "De vergeten 'weeskinderen' van de VOC". NRC 13.01.2017

Vries, F. De. 2012. Afrikaners. Een volk op drift. Amsterdam: Nijgh and Van Ditmar.

Waher, H. 1978. Die probleem van die bereik van die ontkenning met spesiale verwysing na Afrikaans. Unpublished PhD dissertation, University of Cape Town. https://open.uct.ac.za/bitstream/handle/ 11427/16763/thesis_hum_1978_waher_hester.pdf?sequence=1\&isAllowed=y (retrieved 04.12.2020).

Waher, H. 1983. "Die tweede ontkenningspartikel in Afrikaans." In: Sinclair, A. (ed.). G.S. Nienaber ' $n$ huldeblyk. Bellville: University of Wes-Kaapland: 695-703.

Webb, V.N. 1997. "Afrikaans in een democratiserend Zuid-Afrika". Ons Erfdeel 40. 225-236.

Webb, V.N. 2002. Language in South Africa: The role of language in national transformation, reconstruction and development. Amsterdam/Philadelphia: John Benjamins.

Webb, V. and M. Kriel. 2000. "Afrikaans and Afrikaans nationalism". International Journal of the Sociology of Language 144. 19-49.

Wielligh, G.R. von. 1925. Ons geselstaal. 'n Oorsig van gewestelike spraak soos Afrikaans gepraat word. Pretoria: Van Schaik.

Willemse, H. 2011. "Reshaping remembrance - A coloured expert's coloured". In: Grundlingh, A. and S. Huigen. (eds.). Reshaping Remembrance. Critical essays on Afrikaans Places of Memory. Amsterdam: Rozenberg Publishers: 23-32.

Willemse, H. 2015. The hidden histories of Afrikaans. Johannesburg: Mapungubwe Institute for Strategic Reflection (Mistra). www.up.ac.za/media/shared/45/willemse_mistra-20151105-2_2.zp80127.pdf (retrieved 07.08.2016).also published Tydskrif vir Letterkunde 53 (2016), 1-14.

Willemse, H. 2017. "More than an oppressor's language: reclaiming the hidden history of Afrikaans". The Conversation 27.04.2017, https://theconversation.com/more-than-an-oppressors-language-reclai ming-the-hidden-history-of-afrikaans-71838 (retrieved 28.04.2017).

Willemse, H. 2019. "DAK-konferensie: "Oor die taal wat miere daidelik is" Paper presented at the DAK conference 'Waarheid en versoening oor Afrikaans, Pinelands Cape Town 30-31.03.2019. Litnet 04.04.2019, https://www.litnet.co.za/dak-konferensie-oor-die-taal-wat-miere-daidelik-is/ (retrieved 09.05.2019).

Williams, Q. 2021. "Kaaps is the future of Afrikaans". Litnet 30.03.2021, https://www.litnet.co.za/kaapsis-the-future-of-afrikaans/ (retrieved 30.03.2021).

Winkel, J. te. 1896. "Het Nederlandsch in Noord-Amerika en Zuid-Afrika". Vragen van den Dag 11. $337-362,418-442$ and $483-505$.

Wouden, T. van der. (ed.). 2012. Roots of Afrikaans. Selected writings of Hans den Besten. Amsterdam/Philadelphia: John Benjamins.

Wren, C.S. 1989. "Blacks shaped language of Apartheid". The New York Times 16.05.1989

Zimmer, S. 1992. "On language genesis: the case of Afrikaans." In: Pearson, R. (ed.). Perspectives on Indo-European language, culture and religion, studies in honor of Edgar C. Polomé. McLean, Virginia: Institute for the Study of Man: Vol. 2. 347-359.

Zyl, A. van and J. Rossouw. 2016. "Die Afrikaanse Taalmuseum en -monument in die Paarl: 40 jaar later." Tydskrif vir Geesteswetenskappe 56. 1-3. 